41 
3.01

$\tau$

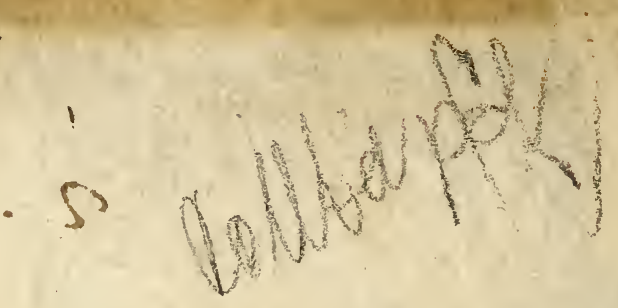

ใै -

- s d d W

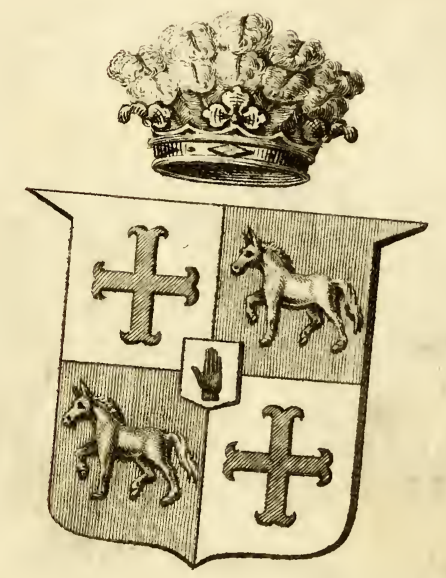

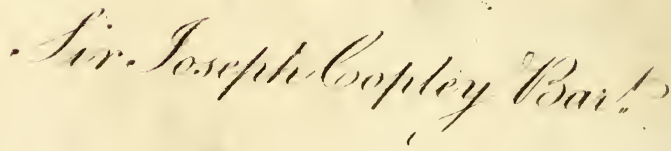





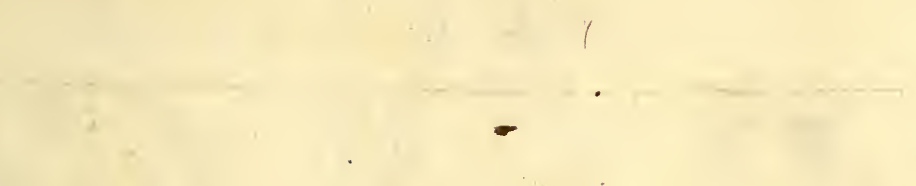

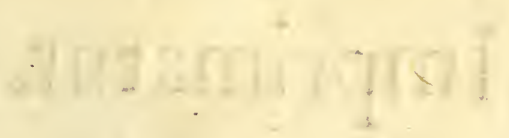

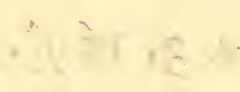

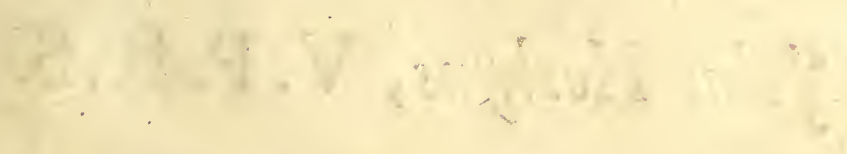

- 


\section{Imprimatur.}

Jan. $3 \cdot 169_{5}^{4}$

$$
\text { fobn Hoskyns, V.P. R.S. }
$$




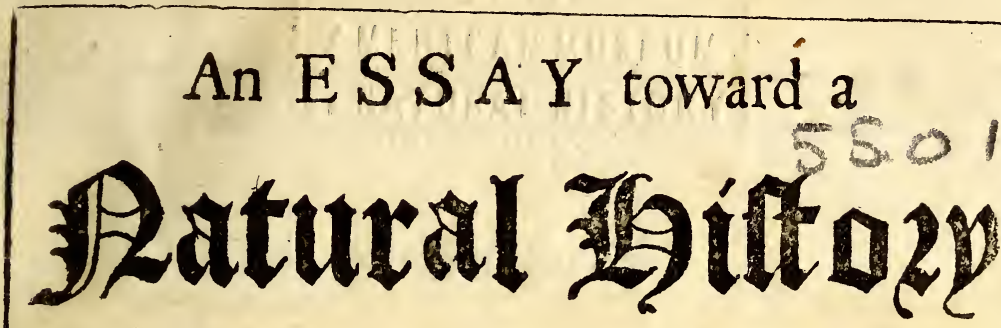 \\ O F T H E

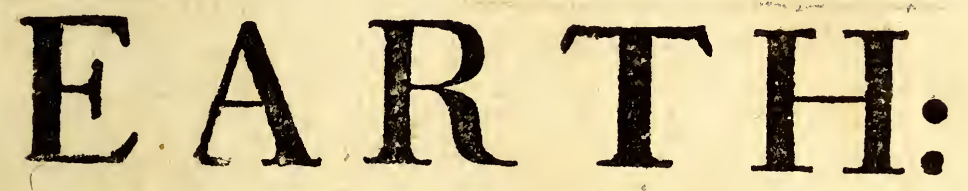 \\ A N D \\ Terreftrial Bodies, Efpecially \\ M I N E R A L S: As alfo of the \\ Sea, Rivers, and Springs. With an Account of the \\ UNIVERSAL DELUGE: \\ And of the Effects that it load upon the \\ E A R $\quad T H$. \\ By Fobn Woodroard, M. D. Profeffor of Phyfick in Grefham-College, and Fellow of the Royal Society. \\ LONDON: Printed for Ric. Wilkin at the Kings-Head in St. Paul's Church-yard, $1695^{\circ}$}




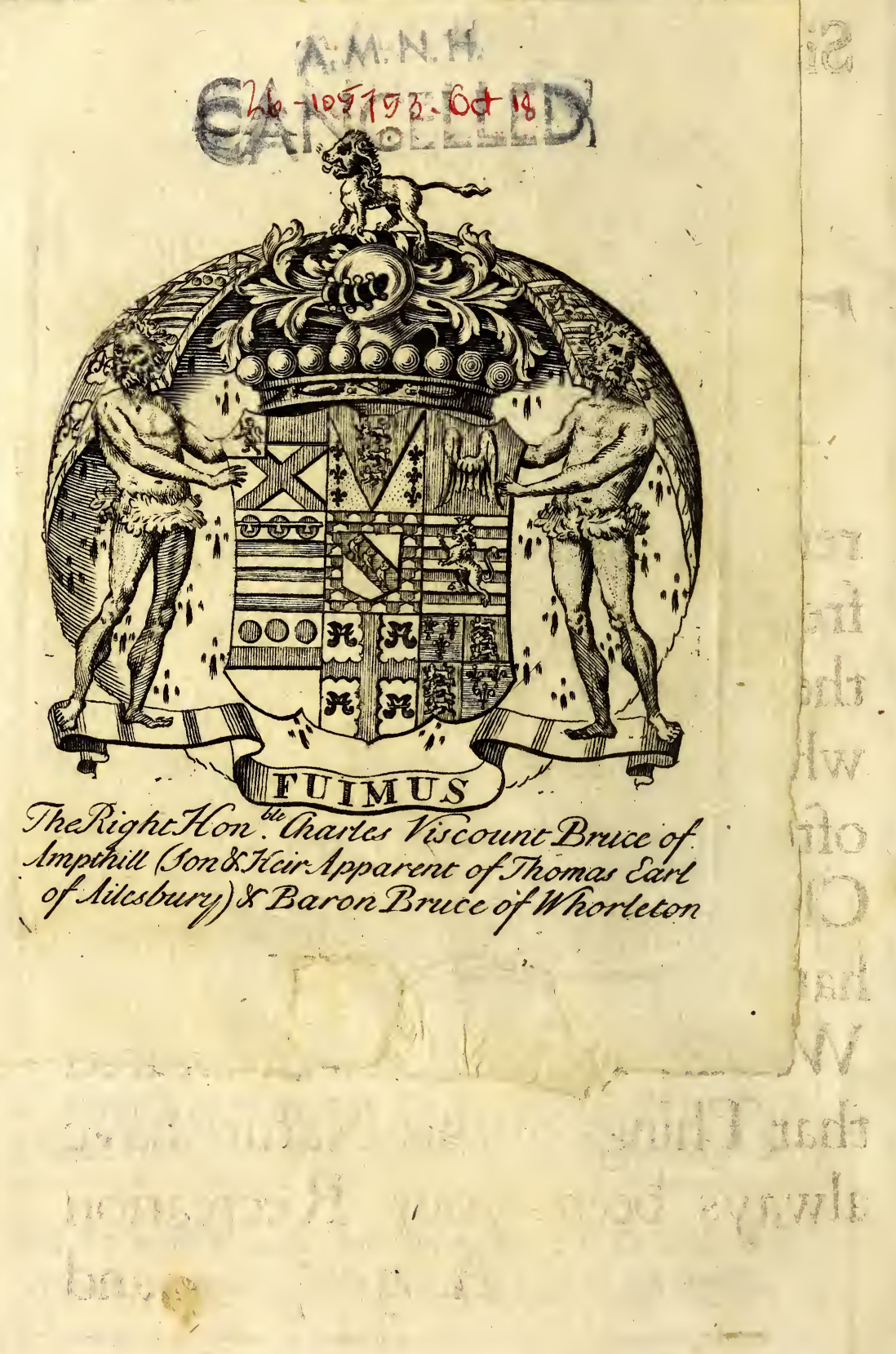




\title{
To the Honourable
}

\section{Sir Robert Soutbroell, Knight,}

\author{
Prefident of the Royal Society.
}

$S I R$,

HE Subject of thefe fol-
lowing Papers being Pbi-
lofopbical, and fo not foreign to the Converfations you frequent, I could not direct them better than to the Perfon whom the Royal Society have fo often made choice of to fill their Chair. For tho' your Bufiners hath been much in the open World, yet am I well affured that Things of this Nature have always been your Recreation

$$
\text { A } 3 \text { and }
$$


and Delight. The Truth is, your Attention to hear me difcourfe of my Travels under Ground, and the Ufes I propoled of what there I found, gave me no fmall Encouragement to expofe my Obfervations to the publickV iew: And 'tis my Hope, that thofe Things may find Pardon from others, which have had Approbation with you. I am very truly,

\section{S I R,}

\section{Your moft humble Servant,}

\section{‡. WOODWARD.}




\section{P R E F C E.}

Thaing in the Effay it Jelf given Some Intimation botb of the Deinduced me to make it pullick, I pall not bere keep the Reader in fuspenfe much longer than only while 1 acquaint bim that, propofing to draw a confiderable number of Materials into $\int 0$ narrow a Compass that they might all be contained in this Jmall Volume, I was obliged to be very brief and concise, And therefore, as Pieces of $\mathrm{Mi}_{\mathrm{i}}$ niature, Sculpture, or other Workmanfbip in little, muft be allowed a clofer Inpection, Jo this $\mathbf{I}$ reatife will require fome Care and Application in the Perufal.

Not but that 1 bave endeavoured, as far as was practicable in fo little room, $\int 0$

A 4 


\section{Preface.}

to dispofe and order things, by interweaving with the Affertions Jome of the Proofss whereon they depend, and occafonally feattering Several of the more important Obfervations throughout the Work, that it will be no very bard Task for any one to difcoper the main Grounds whereon all that 1 here advance is founded.

That this may be the more clearly apprebended, I Shall beg leave to illuftrate it by one or two Inftances. It will perbaps at firft fight feem very ftrange, and almoft bock an ordinary Reader to find me afferting, as I do, that the whole Terreftrial Globe was taken all to pieces and disfolved at the Deluge the Particles of Stone, Marble, and all otber folid Foffils diffevered, taken up into the Water, and there Juftained together with sea-fbells and other Animal and Vegetable Bodies: and that the preenent Earth confifts, and was formed out of that promiccuous Maß of Sand, Earth, Shells, and the reft, falling 


\section{Preface.}

falling down again, and Jubfiding from the Water. But whoever fball duely attend to what I el fewhere lay down, viz. that there are Daft Multitudes of Shells, and other Marine Bodies, found at this day incorporated with and lodged in all forts of Stone, in Marble, in Cbalk, and to be fhort, in all the other ordinary Matter of the Globe which is clofe and compact enough to preferve them: that the ese are found thus repofited among ft this Terreftrial Matter from near the Surface of the Earth downwards to the greateft Depth we ever dig or lay it open, and this in all Parts of it quite round the Globe: that the Said terreftrial Matter is dispofed into Strata or Layers, placed one upon another, in like manner as any eartby Sediment, fetling down from a Fluid in great quantity, will naturally be: that the e Marne Bodies are now found lodged in thofe Strata according to the Order of their Gravity, thofe which are beavieft lying deepefo 


\section{Preface.}

deepeft in the Earth, and the lighter forts (wben there are any fuch in the fame place) fhallower or nearer to the Surface: and botb thofe and thefe amongft terreftrial Matter which is of the Same specifick Gravity that they are, the beavier Shells in Stone, the lighter in Chalk, and Jo of the reft; I fay, wboever Jball but rightly weigh all this, be'll bave no need to go further for Proof that the Earth was actually fo. diffolved, and afterwards framed a-new, in Juch manwer as I bave fet forth. And if to this be fhall think fit to add the other. Arguments of the Same Thing which be will meet with in their Place, they also will I bope not fail of doing their Part in convincing bim ftill more of the Truth and Certainty of this Matter.

The otber Inftance I make choice of Shall be of the Univergality of the Deluge, which is anotber Propofition that I infif upon. And for this, let but the Reader please to confider, what I deliver from autbentick Rela- 


\section{Preface.}

Relations, that the marine Bodies aforefaid are found in all Parts of the known World, as well in Europe, Africa, and America, as in Afia, and this even to the pery tops of the bigheft Mountains; and then I tbink be cannot reafonably doubt of the Propofition: but more especially if bereunto be fball joyn what I offer concerning the Great $A b y \beta$, and thence learns that there is at this day refident, in tbat buge Conceptacle, Water enougb to effeet Juch a Deluge, to drown the wbole Globe, and lay all, even the bigheft Mountains under Water. But if be Jbould be at a lo $\beta$ to know bow I got Jucb Notice of that Jubterranean Refervatory, as to enable me to make a Computation of the Quantity of Water now conceal'd therein, if be carefully perufe the Propoffitions concerning Eartbquakes, and fome otbers in the Third Part, be cannot but difcover at leaft fome of the ways whbereby I got light thereint, : and at the Jame time find why it is that I am fo particular 


\section{Preface.}

ticular in relating the Phxnomena of Eartbquakes, and dweil so long upon that Subject in this Jborter Work.

Thefe I intend for Example and DireEtion to the Reader bow be may Satisfie bimself in any of the otber Heads. 'Tis impoffible for me to forefee the Difficulties. and Haferations of every one: they will be more or fewer, according to the Capacity of each Perufer, and as bis Penetration and Infight into Nature is greater or le $\int s$. They who bave Attention enough to t ke in the intire Platform as bere laid down: who fee the Chain which rins through the whole: and can pick up and bear in mind the $\mathrm{Ob}$ Servatinns and Proofs bere and there as they lie, and then confer thom with the Propoftitions, will difcern (in great meaJure) bow these Propofitions flow from them: but they who cannot fo eafily do this must be intreated to bave a little paiience, wintill the Thing be furtber unfolded, and more amply and plainly made out.

A few 


\section{Preface.}

A few AdDances there are in the following Papers, tending to affert the Superintendence and Agency of Providence in the Natural World: as alfo to evince the Fidelity and Exactne $\beta$ of the Mofaick Narrative of the Creation, and of the Deluge. Which tis not improbable but Some may be apt to fumble at, and think ftrange that in a Pbyjical Difcourse as this is, I Jould intermeddle with Matters of that kind. But I may very Safely Say, that, as to the former, I bave not entered farther into it than meerly I was lead by the nect/fity of my Subject: nor could I bave done le $\beta$ than I bave, without the moft apparent Injury and Injuftice to Trutb. And for Moles, be baving given an Account of fome Things wbich I bere treat of, I was bound to allow bim the Jame Plea that 1 do other Writers, and to confider what be bath delivered. In order to this I fet afide every thing that might byaß my Mind, oper-awe, or millead me in the

Scrutiny', 


\section{Preface.}

Scrutiny, and therefore bave regard to bim bere only as an Hiftorian. I freely bring what be bath related to the $T_{e f}$, comparing it with Things as now they ftand: and finding bis Account to be punEtually true, I fairly declare what I find; wherein I do bim but fimply Right, and only the fame that I would to a common. Hifforian, to Berofus or Manetho, to Herodotus or Livy, on like occafion. 


\section{The CONTENTS.}

A $N$ Account of the Obfervations upons A which this Difcourfe is founded. P. I.

ADiffertation concerning Sbells and other Marine Bodies, found at Land; proving that they were originally generated and formed at Sea: that they are the real Spoils of once living Animals: and not Stones, or natural Foffils, as fome Learned Men bave tbought. p. 15.

\section{PART I.}

An Examination of the Opinions of former Writers on this Subject. The Means whereby they thought the fe Marine Bodies brought out upon the Earth. Of certain Changes of Sea and Lond, and other Alterations in the Terragueous Globe, whicb they Suppofe to bave bappened.

\section{PART II.}

p. 34 .

Concerning the Univerfal Deluge. That thefe Marine Bodies were then left at Land. The Effects it had upon the Earth。 


\section{P A R T III.}

Concerning the Fluids of the Globe.

Sect. I. Of the great Aby/s. Of the Oct ${ }^{\circ}$ an. Concerning the Origin of Springs, and Rivers. Of Vapours, and of Rain.

p. II 5 .

Sect. II. Of the Univer fality of the Deluge. Of the Water which effected it. Together with fome further Particulars concerning it.

\section{PAR T IV.}

p. $157^{\circ}$

Of the Origin and Formation of Metalis and Minerals.

\section{PAR T V.}

p. $170^{\circ}$

Of the Alterations which the Terraqueous Globe bath undergone fince the time of the Deluge.

\section{P A R T VI.}

Concerning the State of the Earth, and the Productions of it before the Deluge.

$$
\text { p. } 242 .
$$

$$
E \quad R \quad R \quad A T A \text {. }
$$

DAge 19. Line 6.after Buccina add (,) p. 32. 1. 3. for Cruffaneous read Cruffaceous p. 6r.l. 23. affer. firm add (,)p. 75. 1.14. after precipitated add (,) p.94. 1. 6. after-been add given. p. 168.1. 25. f. Alargatis r. Atargatis.p. 173. 1. 10. (in the Margin) f, it r.the Caid Stone. p. 184.1.13.f.Cocbitter. Conchite. p.243.1.2 1. f.the r. that p. 270.1.2. f. frigitive r. fugitive. p. 275.

1. 12 . (in the Margin) f. the ro tbat. 


\section{A N}

ACCOUNT

OF THE

\section{OBSERVATIONS}

Upon which this

\section{DISCOURSE}

Is Founded.

TROM a long train of Experi4 ence, the World is at length 1 convinc'd, that Obfervations are the only fure Grounds whereon to build a lafting and fubftantial Philofophy. All Parties are fo far agreed upon this matter, that it feems to be now the common fenfe of Mankind.

For which reafon, I fhall in the Work before me, give my felf up to B be 
be guided wholly by Matter of Fact; as intending to fteer that courfe which is thus agreed of all hands to be the beft and fureft: and not to offer any thing but what hath due warrant from Obfervations; and thofe both carefully made, and faithfully related.

And that each Reader may the better inform himfelf, not only of what fort my prefent Obfervations are, but fee in what manner alfo, and with what kind of Accuracy they were made, 'twill be convenient to give fome light into that matter, and to begin with an Account of them; whereby he may be enabled to judge how far they may. be relyed upon, and what meafure of Affent the Propofitions which I draw from them may claim.

But before I go any farther, I ought to put in a Caution, that an ample and prolix Relation either of the Obfervations themfelves, or of the Deductions from them, is not to be expected here. I defign this but for a Sample of what I hope, in good time, more fully to difculs and make out : propofing no more in this Treatife, than only, in a few plain words, to deliver my Sentiments on certain Heads of Natural Hiftory, 


\section{of the Earib.}

Hiftory, with fome of the Reafons and Grounds of them, in order to give fomewhat of prefent Satisfaction to the Curiofity and Demands of fome of my Friends.

The Obfervations I fpeak of were all made in England; the far greateft part whereof I travelled over on purpofe to make them : profeffedly fearching all places as I pass'd along, and taking a careful and exact view of Things on all hands as they prefented, in order to inform my felf of the prefent condition of the Earth, and all Bodies contained in it, as far as either Grotto's, or other Natural Caverns, or Mines, Quarries, Colepits, and the like, let me into it, and difplayed to fight the interiour Parts of it; not neglecting, in the mean time, the exteriour or furface, and fuch Productions of it as any where occurred, Plants, Infects, Sea, River, and Land Shells ; and, in a word, whatever either the Vegetable or Animal World a fforded.

Nor did I confine thefe Obfervations to Land, or the Terreftrial Parts of the Globe only, but extended them to the Fluids of it likewife, as well thofe, within it, the Water of Mines, of

$$
\text { B } 2
$$


Grotto's, and other fuch like Receffes, as thofe upon the furface of it, the Sea, Rivers, and Springs.

My principal Intention indeed was to get as compleat and fatisfactory information of the whole Mineral Kingdom as I could poffibly obrain. To which end, I made ftrict enquiry wherever I came, and laid out for intelligence of all Places where the Entrails of the Earth were laid open, either by Nature (if I may fo fay) or by Art, and humane Induftry. And wherefoever I had notice of any confiderable natural Spelunca or Grotto; any digging for Wells of Water, or for Earths, Clays, Marle, Sand, Gravel, Chalk, Cole, Stone, Marble, Ores of Metals, or the like; I forthwith had recourfe thereunto: and taking a juft account of every obfervable Circumftance of the Earth, Stone, Metal, or other Matter, from the Surface quite down to the bottom of the Pit, I entered it carefully into a Journal, which I carry'd along with me for that purpofe. And fo palfing on from Place to Place, I noted whatever I found memorable in each particular Pit, Quarry, or Mine: and 'tis out of thefe Notes that 


\section{of the Earth.}

that my Obfervations are compiled.

After I had finifh'd thefe Obfervations, and was returned back to this City, fuch were the Commotions which had then fo unhappily invaded Europe, that I faw I mult neceffarily defift here, and fit down (for the prefent at leaft) with what I had already done; having little profpect of an opportunity of carrying on the $\mathrm{Ce} \mathrm{Ob}$ fervations any farther, or of going beyond Seas, to confider the ftate of the Earth, and of all forts of Folfils, in more diftant Countries.

But to fupply, as far as poffible, that Defect, I made Application to Perfons who had already travelled, and I knew were of fuch Integrity, that they would not impofe uncertain or falfe Relations upon me: as alfo of fo much Curiofity as to be likely to give me fome tolerable infight into the condition of the fe things in Foreign Regions. I likewife drew up a List of Quaries upon this Subjec?; which I difpatch'd into all parts of the World, far and near, wherever either I my felf, or any of my Acquaintance, had any Friend refident to tranfmit thofe Quaries unto.

$$
\text { B } 3 \text { The }
$$


The Refult of this was, that in time I was abundantly affured, that the Circumftances of the fe Things in remoter Countries were much the fame with thofe of ours here - that the Stone, and other terreftrial Matter, in France, Flanders, Holland, Spain, Italy, Germany, Denwark, Norway, and Sweden, was diftinguilhed into Strata, or Layers, as it is in England: that thofe Strata were divided by parallel Fiffures: that there were enclofed in the Stone, and all the other denfer kinds of terreftrial Mdtter, great numbers of Shells, and other Productions of the Sea, in the fame manner as in that of this Ifland. To be fhort, by the fame means I got fufficient intelligence that the e Things were found in like manner in Barbary, in Esypt, in Guiney, and other parts of Africa; in Lrabia, Syria, Perfia, Malabar, China, and other Afratick Provinces; in Famaica, Barbadoes, Virginia, New-England, Brafl, Peru, and other Parts of America. But I referve the more particular Relation hereof to its proper place.

So that though my own Obfervations were confined to England, yet by this means I was made acquainted with 


\section{of the Earth:}

the ftate of thefe Bodies in other Coun. tries; even in almoft all parts of the World wherewith the Englifs maintain any Commerce or Correfpondence: and learn'd from all hands, that the ftate of them there was conformable to that of ours bere, in the main, and as far as I thall lay any ftrefs upon it in my Conclufions ; which indeed are not built upon any Niceties, or folitary and uncommon Appearances, but on the moft fimple and obvious Circumitances of thefe terreftrial Bodies.

As to the Certainty and Accuratenefs of my Obfervations, thus much may modeftly and very truiy be faid, that I do not offer any one before I had firt thoroughly and clearly informed my felf in all material Circumftances of it, and had opportunity of obferving it in more places than one, that I might be fatisfied there was nothing cafual or contingent in any of thole Circumftances. This will not be thought an over-great exactnels, or any thing more than was needful, by thofe who have noted how much Philofophy hath fuffered by the negleat and overfight of fome Naturalifts in

$$
\text { B } 4
$$

this 
this refpect. A tranfient and perfunctory Examination of things, frequently leads Men into confiderable Miftakes, which a more correct and rigorous Scrutiny would have detected and avoided. The truth is, $I$ have been the more fcrupulous and wary in regard the Inferences drawn from thefe Obfervations are of fome importance: 'twas but neceffary that the Foundation fhould be firm, when a Superftructure of Bulk and Weight was to be raifed upon it. And therefore 1 advance nothing from any Obfervation that was not made with this Caution, and that any Man may not, as well as my felf, without any great pains, inform him. felf of the truth of : And as long as the next Cole-pit, or Mine, the next Qunarsy, or Chalk-pit, will give abundant Atteftation to what $I$ write, the $/ e$ are fo ready and obvious in almoft all places, that I need not be any where far to feek for a Compurgator; and to thefe I may very fafely appeal.

Concerning the Obfervations themfelves therefore, there cannot well arife any doubt but what may be eafily fatiffied: And what I propofe in this Eflay being founded upon thefe Obfervati- 


\section{of the Earth.}

ons, every Reader will be judge of the truth and probability of it, and whether that which I do fo propofe naturally follows from them or not.

I fhall diftribute them into two general Claffes or Sections, whereof the former will comprehend my Obfervations upon all the Terreftrial Matter that is naturally difposed into Layers, or Strata; fuch as our common Sandftone, Marble, Cole, Chalk, all forts of Earth, Marle, Clay, Sand, Gravel, with fome others.

Of this various Matter, thus formed into Strata, the far greateft $\mathrm{p}$ rt of the Terreftrial Globe confifts, from its Surface downwards to the greateft depth we ever dig or mine. And it is upon my Obfervations on this that I have grounded all my general Conclufions concerning the Earth; all that relate to its Form; all that relate to the Univer $\int a l$ and otber Deluges, in a word, all that relate to the feveral Viciffitudes and Alterations that it harh yet undergone. Nay, upon the fame Obfervations I have alfo founded feveral Conclufions touching Metalls, Spar, and other Minerals, which are found lodged either in thefe Strata, amongtt 
the Sand, Chalk, Earth, and the reft; or in the perpendicular Intervals of the Strata of Stone, Marble, or other folid Matter.

For upon the particular obfervations on the faid Metallick and Mineral Bodies, (which are the Subjects of the fecond Section, ) I have not founded any thing but what purely and immediately concerns the Natural Hiftory. of thore Bodies.

To proceed therefore to the Account of my Obfervations upon Sand-ftone.

- And in these, though I do not neglect to note the feveral Kinds or Varieties of it : Free-ftone, Ragg-ftone, Limeftone, and the reft : the different Hardnefs, or Solidity, of each : as alfo its Colour, Texture, and the peculiar matter which conftitutes it: yet I confine my felf more ftrictly to confider the manner how 'tis difpofed in the Earth: the Strata, into which, by

I call those Fiffures, which diflinguifh the Sione into Strata, Horizontal ones; and those which inter fect the fe Perpendicular : not fo much with respect to the prefent fite of the Strata, which (as 1 . jhall fbew) is altered in many places, as to its original fituation: concerning which, fẹ 6 Part 2. Confert. 5 . means of horizontal liand parallel Fiffures, it is divided: the Order and Number of thefe Strata: their fituation in refpect of the Horizon : the Thick: 


\section{of the Earth.}

Thickners, Depth, and other Circumftances of each: the Interruptions of the Strata, I mean the perpendicular $\|$ Fiffures, which interfect the horizontal ones: the different Capacity or Largenefs of thefe perpendicular Intervals: their Diftances from each other : and the Spar, and other Mineral and Metallick Matter, ufually contained in them.

But, becaufe I faw that Deductions of confiderable import and confequence might be drawn from them, i have with great Care and Intention obferved the Condition of fuch heterogeneous Bodies, which I found immerfed and included in the mafs of this Sandftone; particularly the Shells of $\mathrm{Oy}$ Aters, Mufcles, Scallopes, Cockles, Periwinkles, and very many other marine Productions. I have, I fay, very diligently noted all Circumftances of thele Shells : the vaft Numbers of them; the feveral kinds that are thus lodged in the fubftance of the Stone: the Order and Manner of their pofition in it: the feveral Depths at which they are found: the Matter which they contain in them, and wherewith their Cavities are ufually filled.

There 
There Obfervations about Stone are fucceeded by others, of like narure, concerning Marble, Cole, and Chalk: their fiffures: the Situation of their Strata : the Shells, and other heterogeneous Bodies lodged therein.

In the next place, thofe which concern Marle, Clay, the feveral kinds of Earth, Sand, Gravel, and fome other Foffils : the Shells and other like Bodies, lodged in their Strata : the Pofition of thofe Strata: their Order; their Diftinctions from each other, by the difference of the Matter of each, and by its different Confiftence and Colour; the Strata of thefe laxer kinds of Matter being not ordinarily divided from each other by interpofition of horizontal Fiffures; as thofe of Stone, and fuch other folid Matter, conftantly are.

And laftly, thore which relate to the upper or outmoft Stratum of all : I mean that blackifh Layer of Earth or Mould which is called by fome $G$ ardenEarth, by owhers Under-turf Earth, wherewith the Terreftrial Globe is almoit every where invefted, unlefs it be difturbed, or flung off by rains, digging, plowing, or fome other external force: 


\section{of the Earth.}

force; infomuch, that whatfoever lies deeper, or underneath, whether Stone, Marble, Chalk, Gravel, or whatever elfe, this Stratum is ftill expanded at top of all ; ferving, as it were, for a common Integument to the reft : and being (as thall be thewn in due place) the Seminary or Promptuary that furnifheth forth Matter for the formation and increment of Animal and Vegeta. ble Bodies ; and into which all of them fucceffively are again finally returned.

The Obfervations being thus difpatch'd, my next ttep fhould have been to have propofed the Deductions from them; to have determined how thefe Sea-Phells were brought to Land, and how they became interr'd in the bowels of the Earth, in the manner defcribed in thofe Obfervations. But before I could proceed any farther towards that, I found my felf neceffarily obliged to take off a difficulty not long fince ftarted by fome learned Men, who fufpect that thefe Shells are not real; that they were never bred at Sea ; but are all of Terreftial Original, being meer Stones, though they bear a refemblance of Shells, and formed, in the places where they are now found, 
found, by a kind of Lufus of Nature, in imitation of Shells.

How nearly I am concerned to remove this Obftacle, before I pafs on any farther to the profecution of my Defign, any one may prefently fee. For to go about to enquire at what time, and by what means thefe Shells were conveyed out of the Sea to dry Land, when a Doubt hath been moved whether they are Shells or not, or ever belonged to the Sea, without firft clearing this Matter, and putting it quite out of doubt; would be fenfelefs and abfurd. In order therefore unto this, I premife 
A Difertation concerning Shells and otber marine Bodies, found at. Land; Proving that they were originally generated and formed at Sea: that they are the real spoils of once living Animals : and not Stones, or natural Foffls, as fome late Learned Men bave tbought.

Shall be the more brief and fparing in my Extract of this Differtation, in regard that coming on thus in order before the other Parts of this Work, it will it felf, of courfe, fee the Light fomewhat fooner than they, any of them will. For which reafon, I hall at prefent only fay thus much of it in general; that therein I firft fairly lay before the Reader the Arguments that have been urged by thefe Gentlemer: to perfwade us that thefe Bodies are mere Mineral Subftances; and having detected the infufficiency of them, by evincing from the moft plain and fimple Reafon, how far they are from being conclufive, and how much they 
fall thort of proving what they are alledged for; I then proceed to lay down my own, and offer thofe Reafons which have induced me to believe that thefe are the very Exuvice of Animals, and all owing to the Sea.

I would not be thought to infinuate that the $\mathrm{O}_{r}$ inion of thefe Gentlemen carries no lhew of Truth, nor umbrage of Reafon of its fide. 'Tis not to be fuppofed, that Perfons of their Learning and Abilities would ever have efpoufed it, were it not in fome meafure plaufible: and had not at leaft a fair appearance of probability. The very finding thefe Bodies included in Stone, and lodged in the Earth together with Minerals, was alone enough to move a Sufpicion that thefe were Minerals too: the finding them even to the very bottom of Quarries and Mines : in the moft retired and inward Parts of the molt firm and folid Rocks: in the deepent bowels of the Earth, as well as upon the furface of it : upon the tops of even the higheft Hills and Mountains, as well as in the Valleys and Plains: and this not in this or that Province only, not only in one or two Fields, but almoft everywhere : 


\section{of the Earth.}

where: in all Countries and Quarters of the Globe, wherever there is any digging for Marble, for Stone, for Chalk, or any other Terreftrial Matter that is fo compact as to fence off external Injuries, and hield them from Decay and Rottennefs. This, together with their " being lodged in company " of the Belemnites, Selenites, Mar"chafits, Flints, and other like Bo"dies, which were inconteftibly na"tural Foffils, and, as they fuppofed, "in the place of their formation," was enough to ftagger a Spectator, and make him ready to entertain a belief that thefe were fo too. 'Tis a Phanomehon to furprizing and extraordinary, that 'tis not ftrange that a Man fhould fcarcely credit his very Senfes in the cafe : that he fhould more readily incline to believe that they were Minerals, as the Belemnites, and the others recited, are : or indeed almoft any thing elfe rather than Sea-fhells; efpecially in fuch Multitudes, and in places fó unlikely: fo deep in the Earth, and far from the Sea, as thefe are commonly found.

Nor was this, as indeed they tell 1 . 
Perfons had to furmount; "They "found, together with thefe, certain "Bodies that bore the fhape and refem"blance of Cockles, Mufcles, and other "Shells, which yet were not really fuch; "but confifted intirely, fome of them, " of Sand-ftone : others of Flint, and "others of Spar: or fome other kind " of Mineral Matter."

3. Nay, they met with fome, "That "were in all appearance Shells : that "were of the fame bignefs, figure, and "texture, with the common Echini, "Scallops, and Perewinkles; but had "notwithftanding Flint, Native-Vi"triol, Spar, Iron-Ore, or other Me" tallick or Mineral Matter, either ad" hering firmly in lumps to the out"fides of them, or infinuated into their "fubftance, into their pores, and in"ner parts, fo as to difguife them very " much,and give them a face and mien "extremely unlike to that of thofe "Shells which are at this day found at "Sea."

They obferved alfo, that "amongft

4. "the Shells, that were fair, unaltered, " and free from fuch Mineral Infinua"tions, there were fome which could " not be match'd by any fpecies of "Shell- 


\section{of the Earth.}

"Shell-fifh now found upon the Sea-

" Thores.

And that on the contrary, "there 50

"were feveral Shells found commonly "upon the faid Shores, fuch as the "larger Shells of the Buccina of the "Conche Veneris ; of Crabs, Lobfters, " and others, both of the Cruftaceous. " and Teftaceous kind, which yet we " never met with at Land, or in our "Quarries."

Nay there were fome other Difficulties which they have urged, and which (though they be of leffer weight) Thall all of them be recounted and confidered more particularly in the Differtation it felf.

Upon the whole therefore 'tis very plain, that thefe Authors did not efpoufe this Opinion without fome grounds: without fome countenance of probability: and that they have charged the oppofite with a large crowd of Difficulties. Yea, fo far are they from being deftitute of an handfome Apology, that they very well deferve the Thanks of the world for what they have done. For although they have not fucceeded in their Attempts about the Origin of thefe Bodies, yet they

$$
\text { C } 2 \text { have }
$$


have made Difcoveries in other refpects concerning them, and in other parts of Nature likewife, of that moment and confequence, as to have thereby laid a great and lafting Obligation upon the intelligent and difcerning part of Mankind.

But that they have failed notwithftanding in this Enterprize, tis, I think, not over difficult to prove. And this is the Subject of the prefent Dif-

I. courfe. Wherein I hope clearly to make out, that the Sea gave Birth to thefe Bodies: that they are fo far from being formed in the Earth, or in the places where they are now found, that

+ Part 4. I fhall evince, t that even the Belem-

nites, Selenites, Marchafits, Flints, and other natural Minerals, which are lodged in the Earth, together with thefe Shells, were not formed there, but had Being before ever they came thither: and were fully formed and finithed before they were repofed in that manner.

2. That the above-mentioned Bodies which confift of Stone, of Spar, Flint, and the like, and yet carry a refemblance of Cockles, Mufcies, and other Shells, were originally formed in the 


\section{of the Earth.}

Cavities of Shells of thofe kinds which they fo refemble; thefe Shells having ferved as Matrices or Moulds to them ; * Concernthe Sand, Sparry and Flinty Matter ing there being then foft, or in a ftate of foluti- Conchitre, on, and fo, fufceptible of any form, $\sigma_{c}$. see when it was thus introduced into thefe Part 4. fhelly-Moulds : and that it confolida- Porrt 5. ted, or became hard afterwards *.

That for the Metallick and Mineral 3 .

Matter which fometimes adheres to the Surfaces of thefe Shells, or is intruded into their Pores, and lodged in the Interftices of their Fibres, 'tis all manifeftly adventitious $\uparrow$; the mineral $+P_{a r t} 4$. Particles being plainly to be diftinguifh-cons. 2 . ed from the teftaceous ones, or the texture and fubftance of the Shell, by good Glaffes, if not by the naked Eye. That though the thing had been fo that this Accretion had not been thus difcernible, and confequently the Alteration of thefe Shells could not have been accounted for, fo that we had been perfectly in the dark as to the Origin of the Bodies thus altered, and that nothing at all could have been determined concerning them; yet this would not have been any the leaft Impediment or objection againft that which

$$
\text { C } 3 \text { I in . }
$$


I infift upon; there being fo very few of thefe in comparifon of thofe which have undergone no fuch Alteration. There being, I fay, befides thefe, fuch vaft multitudes of Shells contained in Stone, \&.c. which are intire, fair, and abfolutely free from any fuch mineral Contagion: which are to be match'd by others at this day found upon our Shores, and which do not differ in any refpect from them: being of the fame fize that thofe are of, and the fame thape precifely : of the fame fubfrance and texture; as confifting of the fame peculiar Matter, and this confitituted and difpofed in the fame manner, as is that of their refpective fellowkinds at Sea : the tendency of the Fibres and Strie the fame: the compofition of the Lamelle, conftituted by thefe Fibres, alike in both : the fame Veftigia of Tendons (by means whereof the Animal is faftned and joyned to the Shell) in each : the fame Papilla: the fame Sutures, and every thing elfe, whether within or without the Shell, in its Cavity or upon its Convexity, in the Subftance, or upon the Surface of it. Befides; thefe Folfil Shells are attended with the ordinary Accidents of 


\section{of the Eartb.}

the marine ones, ex.gr. they fometimes grow to one another, the leffer Shells being fix'd to the larger : they have Balani, Tubuli vermiculares, Pearls, Coral, and the like, ftill actually growing upon them. And which is very confiderable, they are moft exactly of the fame fpecifick Gravity with their fellow-kinds now upon the fhores. Nay farther, they anfwer all Chymical tryals in like manner as the Sea-fhells do: their parts when diffolved have the fame appearance to view, the famefmell and tafte: they have the fame vires and effects in Medicine, when inwardly adminiftrated to Animal Bodies: Aqua fortis, Oyl of Vitriol, and other like Mexaftrua, have the very fame effects upon both. In one word, fo exactly conformable to the marine ones are thefe Shells, Teeth, and Bones, which are digged up out of the Earth, that though feveral Hundreds of them, which I now keep by me, have been nicely and critically examined by very many Learned Men, who are skill'd in all parts of Natural Hiftory, and who have been particularly curious in, and converfant with, Shells, and other marine Productions, yet never any

$$
\text { C } 4 \text { Man }
$$


Man of them went away diffatisfied, or doubring whether thefe are really the very Exurvic of Sea-fifhes or not. Nay, which is much more to my purpofe, fome of the moft eminent of thofe very Gentlemen who formerly were doubtful in this Matter, and rather inclinable to believe that thefe were natural Minerals, and who had wrote in defence of that Opinion, do notwithftanding upon ftrict and repeated Infpection of thefe Bodies in my Collection, and upon farther Enquiry, and procuration of plain and unalter'd Shells from feveral parts of this Inand, fully afient to me herein, and are now convinced that thefe are the fpoils and remains of Sea-Animals. And, being thus fatisfied, fuch is the Ingenuity of thefe worthy Perfons, and fo great their Affection to Truth, when, where, and by whomfoever manifefted, that they have perfonally requefted me to publifh my. Thoughts in order to the fuller clearing of this matter. But to proceed.

4: That although I can pair, with SeaShells, feveral of thefe Foffil ones that thefe Gentlemen have pronounc'd altogether unlike any thing that the Salt- 


\section{of the Earth.}

Water produceth; yet 'tis indeed very true, that there are found fome Shells at Land, in Stone, and in Chalk, which cannot probably be match'd by any fpecies of Shells now appearing upon our Shores. But notwithftanding this, I cannot but affirm that the $e_{3}$, even the moft ftrange and enormous of them, have all the effential Notes and Characters of Sea-Shells, and thew as near a relation to fome now extant upon the Shores, as the different Species of thofe themfelves do to one another: that they are of the very fame fpecifick Gravity with thofe to which they are fo generically allied: and of the fame Texture and Conftitution of parts; the fubftance of the/e being as plainly reftaceous, as that of thofe is; infomuch that any Man that compares them, can no more doubt of the reality of the one than of the other; whence it muft needs follow, that there were fuch Shell-fifh once in being; which is enough for my purpofe; I being no ways concerned to make out that there are of the fame kinds fill actually living in the Ocean." Though if I was, "twould be no very hard task; it being evident from the Relations of Dyvers, and Fifhers 
Fifhers for Pearls, that there are many kinds of Shell-filh which lye perpetually concealed in the Deep, skreen'd from our Eyes by that vaft world of Water, and which have their continual abode at the bottom of the Ocean, without ever approaching near the Shores, it being as unnatural for the e e to defert this their native ftation, as 'tis for thofe that are the inhabitants of the Shores, to quit theirs, and retire into the deep : that for this reafon these are called by Naturalifts subuistoot, and Pelagie, as the others, that refide nearer to the Shores, are by them called Littorales. Now the Shells which we find expofed upon our Shores, are only thofe which are caft up and ftranded by tides and by ftorms; and confequently are all of them Exuvia of thofe kinds that live near the Shores, and not of thofe that inhabit the Main, or the deeper and remoter parts of the Ocean ; it being certain from the Relations alfo of Dyvers, that the Tides and Storms, even the moft tempeftuous and turbulent, affect only the fuperficial parts of the Ocean, the Shallows, and Shores, but never reach the greater Depths, or difturb the bottom 


\section{of the Earth.}

of the Main: thefe are as quiet, and free from Commotion in the midft of ftorms, as in the greateft calm; fo that the Shell-filh, which are refident in thefe places, live and dye there, and are never diflodged or removed by ftorms, nor caft upon the Shores, which the Littorales ufually are. When therefore I hall have proved more at large, that thofe which we find at Land, that are not matchable with any upon our Shores, are many of them of thofe very kinds which the forecited Relations particularly affure us are found no where but in the deeper parts of the Sea : and that as well thofe which we can match, as thofe we cannot, are all Remains of the univerfal Deluge, when the Water of the Ocean, being boifteroufly turned out upon the Earth, bore along with it, Filhes of all forts, Shells, and the like moveable Bodies, which it left behind at its return back again to its Chanel, it will not, I prefume, be thought ftrange, that amongt the reft, it left fome of the Pelagia, or thofe kinds of Shells which naturally have their abode at main-fea, and which therefore are now never flung up upon the Shores: 
and it may very reafonably be concluded, that all thefe frange Shells, which we cannot fo match, are of thefe $P e$ lagie : that the feveral kinds of them are at this day living in the huge bofom of the Ocean: and that there is not any one intire fpecies of Shell-fifh, formerly in being, now perifh'd and loft.

5. That it is alfo very true that there are fome Shells, fuch as thofe of the larger Buccins, and Conche Veneris, of Lobiters, Crabs, and others of the cruftaceous kind, that are very rarely found at Land; fo rarely, that fome of thefe Gentlemen have afferted that they are never found; but that I thall fhew to be a miftake, all the Shells in their whole Lift having been found in the Earth in one place or other. But that thefe are very feldom found any where, I moft readily grant; and this is fo far from being an Argument againft what I am going to advance, that 'tis as full and fubftantial a Proof of the truth of it as I could polfibly wifh. For the Shells in this Lift are all lighter than Stone, Marble, and the other ordinary Terreftrial Matter. Now both thefe and all other forts of 


\section{of the Earth.}

Shells that are fo light, occur very feldom at Land, or in the Earth, in comparifon of the Shells of Cockles, Perewinkles, and the reft which are more ponderous, fo as to equal the Stone, and the other Terreftrial Matter in Gravity. The Reafon of which will be very plain, when I thall have thewn * that at the time of the Deluge * $v_{i d}$. (when thefe Shells were brought out Part 2. upon the Earth, and repofed therein in the manner we now find them ) Stone, and all other folid Minerals, loft their folidity: and that the fever'd Particles thereof, together with thofe of the Earth, Chalk, and the reft, as alfo Shells, and all other Animal and Vegetable Bodies, were taken up into, and fuftained in, the Water: that at length all thefe fubfided $\uparrow$ again pro- + viz. mifcuoully, and without any other ${ }_{\text {Cont } .3 .}$. 2. order than that of the different ppecifick Gravity of the feveral Bodies in this confufed Mafs, thofe which had the greateft degree of Gravity finking down firft, and fo fetling loweft; then thofe Bodies which had a leffer degree of Gravity fell next, and fertled fo as to make a Stratum upon the former; and $f_{0}$ on, in their feveral turns, to 
the lighteft of all, which fubfiding laft, fettled at the Surface, and covered all the reft: that this very various Mifcellany of Bodies being determined to fubfidence in this Order meerly by their different fpecifick Gravities, all thofe which had the fame degree of Gravity fubfided at the fame time, fell into, and compofed, the fame Stratum; fo that thofe Shells, and other Bodies, that were of the fame fpecifick Gravity with Sand, funk down together with it, and fo became inclofed in the Strata of Stone, which that Sand formed or conftituted: thofe which were lighter, and of but the fame fpecifick Gravity with Chalk (in fuch places of the Mafs where any Chalk was) fell to the bottom at the fame time that the Chalky Particles did, and fo were entombed in the Strata of Chalk; and in like manner all the reft : that accordingly we now find in the Sand-ftone of all Countries (the fpecifick Gravity of the feveral forts whereof is very little different, being generally to water as $2 \frac{1}{2}$ or $2 \frac{2}{16}$ to I) only thofe Conclis, Pectines, Cochleae, and other Shells that are nearly of the fame Gravity, (viz. $2 \frac{1}{3}$ or $2 \frac{5}{8}$ to I) but thefe are ordinarily found 


\section{of the Earth.}

found enclofed in it in prodigious numbers; whereas of Oyfter-hells, (which are in Gravity but as about $2 \frac{1}{3}$ to 1 ) of Echini (which are but as 2 or $2 \frac{1}{8}$ to 1 ) or the other lighter kinds of Shells, fcarce one ever appears therein; but, on the contrary, in Chalk (which is lighter than Stone, being but as about $2 \frac{1}{10}$ to 1) there are only found Echini, and the other lighter forts of Shells; it being extreamly unufual to meet with fo much as one fingle Shell of any of all the heavier kinds amongft Chalk; but for the faid Echini, and other the lighter forts of Shells, they. are very numerous and frequent, in all the Chalk-pits of Kent, Surrey, Es]ex, Hartfordjbire, BarkJbire, Oxfordbire, and all others that I have fearch'd; being found indifferently in the beds of Chalk from the top quite down to the bottom of the Pit; I having my felf commonly obferved them to the very bottom of all, in Pits that were an hundred foot deep, and in Wells much deeper. To conclude, thofe shells, and other Bodies, that were ftill lighter than the $e$, and confequently lighter than Stone, Chalk, and the other common Matter of the Earth, fuch as 
the Shells of Lobfters (which are butt as I $\frac{1}{3}$ to I ) of Crabs, (I $\frac{3}{4}$ to I) and the reft of the Cruftaneous kind: the Teeth and Bones of the cartilaginous and fquammofe Fifhes, and many other Bodies, would fubfide laft of all, and fo, falling above the reft, be lodged near, if not upon the Surface; where being continually expofed to Weather, and other Injuries, they muft in tract of time needs decay and rot, and at laft quite vanilh and difappear; and 'tis not to me any great wonder, that at this diftance of four thoufand years, we find fo very few of them remain ing. So that I think I may now fafely appeal to any ingenuous and impartial Looker on, whether this, That we find all thofe kinds of Shells (now extant upon our Shores) which bave nearly the fame Gravity with Stome, and the other ordinary Matter of our Earth, that is fo tight and compact as to preferve them, enclofed in great plenty tberein, and only thofe, the rest which are lighter being fo very rarely found, can reafonably be fuppofed to have happened by meer chance, with this Conftancy and Certainty, and that in fo many and diftant Places: as alro; whether this be anny

Objection 


\section{of the Earth.}

Objection againtt my Hypothefis; or rather be not the ftrongeft acceffary Confirmation of it that could well be expected, or even defired.

To this Differtation I thall fubjoyn an Appendix, which will confift of feveral Sections, touching the Bodies called Unicornu Foffile, Lapis Fudaicus, Entrocbus, Afteria, or the Star-ItoneColumns: with fome farther Reflections upon the Bufonites, Gloffopetra, and Cornu Ammonis: proving that thefe, and feveral more, which have been (for many Ages) reputed Gemms, and meer Stones, are really nothing elfe but the Teeth, Bones, and other parts of Sea-Animals, and (as the reft were) left behind by the Univerfal Deluge. 


\section{PART I.}

An Examination of the Opinions of former Writers on this Subject. The Means whereby they thought thefe Marine Bodies brought out upon the Earth. Of certain Changes of Sea and Land, and other Alterations in the Terraqueous Globe, which they Juppofe to bave happened.

THIS fo confiderable a point be-

1 ing thus gained: the Legitimacy or Reality of thefe Marine Bodies vindicated and afferted: and my Way fo far effectually cleared by the foregoing Differtation; I now re-affume my original Defign, and pafs on to enquire by what means they were hurried out of the Ocean, the place of their native Abode, to dry Land, and 


\section{Part I. of the Earth.}

even to Countries very remote from any Seas.

And this is a Queftion of great Antiquity; and which hath, for many Ages, given no fmall Fatigue to Learned Men. Nor hath the prefent been lefs inquifitive into this Affair than the former Ages were. We have feen feveral hands employed herein; and many of them very excellent ones too. The great number of the Undertakers: the Worth of fome of them: and their Zeal to bring the Matter to a Decifion, are fure Arguments of the Dignity and Importance of it: and that it is not hitherto decided, is as certain a proof of its difficulty.

Some were of Opinion, that thefe Shells were fetch'd from Sea, by the ancient Inhabitants of thofe Countries where they are now found; who, after they had ufed the included Filhes for Food, flinging forth the Shells, many of them became petrified, as they fpeak; being thereby preferved down to our times, and are the fame which we at this day find in our Fields and Quarries.

Others rather thought that they were only Reliques of lome former

$$
\text { D } 2 \text { great }
$$


great Inundations of the Sea; which, furioully rufhing forth, and overflowing the adjacent Territories, bore thefe Bodies out upon the Earth along with it : but returning at length more leifurely and calmly back again, it left them all behind.

Many were of Opinion, that the Sea frequently flitted and changed its place : that feveral parts of the Globe which are now dry Land, and habitable, lay heretofore at the bottom of the Sea, and were covered by it: that particularly the very Countries, which prefent us with thefe Spoils of it, were anciently in its poffeffion; being then an Habitation of Sharks and other Filhes: of Oyfters, Cockles, and the like; but the Sea, in tract of time, retreating thence, and betaking it felf into new Quarters: gaining as much ground on the oppofite Coafts, as it loft upon thofe, left thefe Shells there as Marks of its ancient bounds and feat.

Amongt the reft there were indeed fome who believed the fe to be Remains of the General Deluge, and fo many Monuments of that calamitous and fasal Irruption. Thefe laft affuredly 


\section{Part I. of the Earth.}

were in the right; but the far greater part of them rather afferted than proved this: rather deliver'd it as their Opinion, than offered any rational $\mathrm{Ar}$ guments to induce others to the fame Belief: And for the reft, who did offer any, fo unhappy were they in the Choice, and unfuccefsful in the $\mathrm{Ma}$ nagement of them, by reafon of the fhortnefs of their Obfervations, and their not having duely informed themfelves of the ftate of thefe Things, that none of the other Partizans appeared with lefs Applaufe : none lefs ftrenuoufly maintained their ground, than thefe did.

*The Truth is, as Matters were or. dered amongt them, no Man could receive much Light or Satisfaction from what was advanced by any of them. They little more than clafbed with one another : each could demolifh the others. Work with eafe enough, but not a Man of them tolerably defend his own; which was fure never to outftand the firft Affault that was made. Yea upon fo equal Terms did they all ftand, that no one could well lay claim to a larger Share of Truth for his fide: no one had a fairer pre-

$$
D_{3} \text { tence }
$$


tence of right, than the reft; and it being impolisble to imagine that all could be in the right; fome Learned Men began to fufpect that none of them were fo.

Thefe thereupon laid out on all hands for fome new Expedient to folve and pur an end to the perplexity; and 'Was this laft Effort that brought forth the Opinion, that thefe Bodies are not what they feem to be; that they are no Shells, but meer Sportings of active Nature in this fubterraneous Kingdom; and only Semblances or Imitations of Shells; they imagining that this thortned the Difficulty, becaule it fpared them the trouble of accounting for their Conveyance from Sea; which was what had fo feverely exercifed all the former; though in reality, this only heightened and enhanfed it, and render'd it ftill more intricate; as will appear more at large when I thall have publifhed the preliminary Differtation, whereof I have already given fome Account above. And this was the moft received and prevalent Opinion when I firft brought my Collection of thefe Things up to Landor.

There 


\section{Part I. of the Earth:}

There have been, befides thefe recited, fome other Conjectures propofed about the removal of thefe Bodies to Land : which I choofe, rather than trouble the Reader with a detail of them here, to deferr to their proper place, that I may proceed directly onwards in my Defign. Now the more effectually to fmooth my way, and that this very great diverfity of Opinions may not be any longer an Amufement to the World, 'twill be very convenient that I look into the Reafons and Pretenfions of each, and hew upon what ground 'tis that I embrace that of the Deluge, and fet afide all the reft.

Why I adhere to them who fuppofe thefe Marine Productions brought out by the Univerfal Deluge, will be beft learn'd from the fucceeding part of this Effay, which is wholly dedicated to that purpofe: and whereunto I Thall prefix, An Hiftorical Account of the Labours of Fab. Columna, Nic. Steno, P. Boccone, Fac. Grandius, Mr. John $R a y$, and other Learned Men, on this Subject: Thewing what they have already done in it, wherein they failed, and what remains ftill to be done.

$$
\text { D } 4 \text { Why }
$$


Why I reject all the other Conjecures, falls under our prefent Confideration; and to make as fhort of the Matter as poffible, "tis becaufe they will none of them abide the Teft : becaufe they have not due warrant from Obfervation, but are clearly repugnant thereunto: in a word, becaufe the prefent Circumftances of thefe Marine Bodies do not fquare with thofe Opinions, but exhibit Phenomena that thwart them, and that give plain Indications that they could never have been pu into the Condition we now find them by any fuch fhort and paitia: Agents as thofe they propofe.

Now in regard that the faid Circumftances are impartially related in my Obfervations, we need only have recourfe to them to put an end to this Bufinefs. For, as Mathematicians fay of a Atreight Line, that 'tis as well an Index of its own Rectitude, as of the Obliquity of a crooked one; fo the $e$ may ferve indifferently to detect the erroneous ways, and to point forth the true; and it is from thefe Obfervations : from the Number, Order, $\mathrm{Va}$ riety, Situation, Depth, Diftance from the 


\section{Part I. of the Earth.}

the Sea, and other Accidents of thefe Bodies, that I thall thew

That they were not brought from Sea to the Parts where they are now found, by Men, the ancient Inhabitants of thofe Parts, as fome Authors have been of Opinion; they prefuming that thefe Shells were at firlt only flung out upon the Surface of the Earth; and that thofe which we now find buried in it, were, in tract of time, covered, either by that Terreftrial Matter which falls down along with rain, or by the Earth which is wahh'd from off the Hills by Land floods.

That they were not carry'd together with the Water, which fome fuppofe to pafs continually from the botrom of the Sea, to the Heads of Springs and Rivers, through certain fubterranean Conduits or Chanels, untill they were by fome Glut, Stop, or other means arrefted in their Paffage, and fo detained in the Bowels of the Earth; as others have rather inclined to believe.

That they were not born forth of the Sea, and laid upon the Land by particular Inundations; fuch as were the Ogygean, the Deucalionian, and others of frefher date: fuch as are 
thofe which ufually attend Earthquakes: or thofe which are fometimes occafioned by very high Tides, by impetuous Winds, and the like; as other Writers have thought.

4. That they were not left behind at the beginning of the World, when the Sea overfpread the whole Globe, till its Retreat into its affigned Chanel, and that the Waters were gathered together unts one place, the third day from the Commencement of the Creation; which others believed.

5. That they were not left by the Seas being contrained to withdraw from off certain tracts of Land, which lay till then at the bottom of it, but being raifed to an higher pitch, fo as tu furmount the Level of the Seas furface, they, by that means, became Inlands and habitable: the faid tracts being thus elevated by Earthquakes, or the like fubterraneous Explofions; in fuch manner as Rbodes, Thera, Therafia, and many other Inlands were fuppofed to have been raifed; which is the ConjeEture of others.

6. That they were not left by the Seas changing its place, receding from the Parts it anciently poffeft, and betaking 


\section{Parc I. of the Earth.}

it felf to new Quarters: this change being occafion'd by fome accidental Emotion or Tranfpofition of the common Center of Gravity in the Terraqueous Globe; and thereupon the Fluids of it, the Sea, and the reft, immediately fhifting likewife, as being the more eafily moveable parts of the Mafs, and coming to another Equilibrium; that they might thereby the better accommodate themfelves to their new Center. As others.

That they were not left upon the Seas being protruded forwards, and conftrained to fall off from certain Coafts, which it formerly poffeffed, by the Mud or Earth which is difcharged into it by Rivers; the faid Mud being repofed along the Shores near the Ostia of thofe Rivers, and by that means making continual Additions to the Land, thereby excluding the Sea, daily invading and gaining upon it, and preferving thefe Shells as Trophies and Signs of its new Acquefts and Encroachments; which others have imagined: they concluding that the Inlands Echinades, the Lower Egypt, ThefJaly, and many other Countries, were thus raifed out of the Mud brought down 
by Acbeluus, the Nile, Peneus, and other Rivers.

8. Laftly. That they were not left by the Seas continual flitting and Thifting its Chanel : this Progreffion being occafioned by the Seas wearing and gaining upon one Shore, and flinging up Mud, and, together with it, thefe Shells, upon the other, or oppofite Coafts, thereby making perpetual Additions unto them; which is the Opinion of other Authors.

Thefe Propofitions (which are no other than fo many Confectaries drawn from the Obfervations) are, we fee, all Negative; as being directed againft the Miltakes of fome who have formerly engaged in this refearch. The ways they have taken to account for the Conveyance of thefe Marine Bodies to Land, are very many, as well as different from each other. For fo eager and follicitous hath the inquifitive and better part of Mankind been to bring this Matter to a fair iffue and determination, that no Stone hath been left unturned, no way, whereby thefe things could ever poffibly have been brought forth of the Sea, but one or other of them hath pitch'd up- 


\section{Part I. of the Earth.}

on it. So that by this Refutation of all thefe, I might prove my own (which is the only one remaining) by Induction; but this kind of proof is not needful, where more cogent and pofitive Arguments are not wanting.

And thus much of this Part I get over by the fole guidance of my Senfes. A View of the prefent ftate of thefe Bodies alone convinced me fufficiently that the means, propofed by thefe Authors, were not the true ones: that they were both levelled wide, and fell all thort of the Mark. Now though this was enough for my prefent purpofe; and when I had evinced that, although fuch Alterations, as thofe which thefe Gentlemen fuppofe: Tranfitions, and Migrations of the Center of Gravity: Elevations of new Inlands: whole Countries gained from the Sea: and other like Changes had actually happened, yet thefe Shells could never porfibly have been repofed thereby in the manner we now find them: I fay, when I had proved this, I was not immediately concerned to enquire whether fuch Alterations bad really ever happened or not; yet partly for a fuller and more effectual Difproof of the re- 
cited Opinions: and partly becaufe I am more efpecially obliged by my general defign to look into all Pretences of Changes in the Globe we inhabit, and I faw very well, that fcarce any, of all thefe alledged, had the leaft countenance either from the prefent face of the Earth, or any credible and authentick Records of the ancient ftate of it, I refolved to purfue this Matter fomewhat farther, and to thew that, although there do indeed happen fome Alterations in the Globe, yet they are very flight and almoft imperceptible, * Part 5. * and fuch as tend rather to the benecorf.r. \&c. fit and confervation of the Earth and its Productions, than to the diforder and deftruction both of the one and the other, as all thefe fuppofititious ones moft manifeftly would do, were there really any fuch; but from clear and inconteftible Monuments of Antiquity: from Hiftory and Geography: and from attentive Confideration of the prefent ftate of thofe Countries where thefe Changes were fuppofed to have been wrought, I prove that they are imaginary and groundlefs, and that fuch in earneft never happened; but that the bounds of Sea and 


\section{Part I. of the Eartb.}

Land have been more fix'd and permanent: and in thort, that the terraqueous Globe is to this day nearly in the fame condition that the Univerfal Deluge left it : being alfo like to continue fo till the time of its final ruin and diffolution, preferved to the fame end for which 'twas firft formed, and by the fame Power which hath fecured it hitherto. But, with refpect to my prefent Defign, I more particularly make out,

That although Rain-water be indeed (as thefe Writers fuppofe) very plentifully faturated with terreftrial Matter, and (as I Thall make appear) that peculiar Matter out of which the Bodies of Vegetables, and confequently of Animals, are formed, nourifhed, and augmented, Water being the common Vehicle and Diftributer of it to the Parts of thofe Bodies, and all Water (efpecially that of Rain) being, more or lefs, ftored with this, it being light in comparifon of the common Mineral earthy Matter, and therefore eafily affumed into Water, and moved along with it; yet that this Matter being all originally derived from the furface of the Earth, either by the va- 
pour that continually iffues out, and $\dagger$ Part 3. afcends from all parts of it, $\uparrow$ or wafh'd Sect. I.
Conj. 8. Rivers and the Sea, and thence elevated up, together with the Vapour, which, as the former, conftitutes the Rain that falls: I fay, it being thus originally all rais'd from the Earth, when reftored back again thereunto, 'tis but where it was before, and does not enlarge the Dimenfions of the Globe, or augment the furface of the Earth, and only lye idly and unferviceably there, but part of it is introduced into the Plants which grow thereon, for their Nutrition and Increment, and the reft, which is fuperfuous, either remounts again, with the afcending Vapour, as before, or is walh'd down into Rivers, and tranfmitted into the Sea, and does not make any fenfible Addition to the Earth, as fome have believed.

That the terreftrial Matter, which is thus carried by Rivers down into the Sea, is fuftained therein, partly by the greater Craffitude and Gravity of the Sea-water, and partly by its conftant Agitation, occafioned by the Tides, and by its other Motions, and 


\section{of the Earth.}

is not permitted to fink to the bottom; or, if any of it do, 'tis raifed up again by the next Storm; and being fupported in the Mafs of Water, together with the reft, 'tis by degrees exhaled, mounted up with the Rain that rifes thence, and returned back again to the Earth in fruitful Showers. That by this perperual Circulation a vaft many things in the Syftem of Nature are tranfacted: and two main Intentions of Providence conftantly promoted; the one a Difpenfation of Water promifcuoully and indifferently to all parts of the Earth; this being the immediate Agent that both bears the conftituent Matter to all formed Bodies; and, when brought to them, infinuates it in, and diftributes it unto the feveral parts of thofe Bodies, for their Prefervation and Growth : the other, the keeping a juft Equilibrium (if I may fo fay) betwixt the Sea and Land; the Water, that was raifed out of the Sea, for a Vehicle to this Matter, being by this means refunded back again into it: and the Matter it felf reftored to its original Fund and Promptuary, the Earth; whereby each is reftrained, and kept to due Bounds; fo that the Sea mey 
not encroach upon the Earth, nor the Earth gain ground of the Sea. That there never were any Illands, or other confiderable parcels of Land, amaffed or heap'd up : nor any enlargement, or addition of Earth made to the Continent, by the Mud that is carried down into the Sea by Rivers. That although the Ancients were almoft unanimoufly of Opinion that thofe Parts, where Egypt now is, were formerly Sea : and that a very confiderable portion of that Country was recent, and formed out of the Mud difcharged into the neighbouring Sea by the Nile; that yet this traet of Land had no fuch Rife, but is as old, and of as long a ftanding, as any upon all the whole Continent of Africa: and hath been in much the fame Natural Condition, that it is at this day, ever fince the time of the Deluge; its Shores being neither advanced one jot further into the Sea for this three or four thoufand Year's, nor its Surface raifed by additional Mud depofed upon it by the yearly Inundations of the Nile. That neither the Palus Meotis, nor the Eaxine, nor any other Seas, fill up, or by degrees grow fhallower. That Salmydeffus, Themi- 


\section{Part I. of the Earth.}

foyra, Sidene, and the adjacent Countries, upon the Coafts of the Euxine Sea, were not formed out of the Mud brought down by the Iffer, Thermodon, Iris, and the other Rivers which difcharge themfelves into that Sea. That Theffaly was not raifed out of the Mud born down by the River Feneus : the Iflands Echinades; or Curzolari, out of that brought by the River Achelous: Cilicia, by the River Pyramsis: Mysia, Lydia, Ionia, and other Countries of Anatolia, by the Caicus, Hermus, Ciayfter, and the other Rivers which pafs through them. To be fhort, That no Ifland or Country in the whole World was ever raifed by this means, notwithftanding that very many Authors, and fome of confiderable note, have believed that all the abovementioned Countries were fo raifed; nay, to fo ftrange a height of Extravagance do fome, otherwife Learned and Curious, Perfons run, when they indulge Fancy too far, and rely wholly upon Probabilities and Conjectures, there is hardly any one fingle Ifland or Country all round the Globe, that one Writer or other hath not thought to have been formed after this manner, or

$$
\text { E } 2
$$


at leaft, fome very large part of it.

That there is no authentick Inftance of any confiderable tract of Land that was thrown up from the bottom of the Sea, by an Earthquake, or other fubterranean Explofion, fo as to become an Illand, and be render'd habitable. That Rhodzes, Thera, Therafia, and feveral other Illands, which were fuppofed by the Ancients, and, upon their Authority, by later Authors, to have been thus raifed, had really no fuch Original, but have ftood out above Water as long as the reft of their Fellow Inands, and ftand now juft as the Univerfal Deluge left them.

That as to that affection of Bodies which is called their Gravity, it clearly furpaffes all the Powers of meer $\mathrm{Na}$ ture, and all the Mechanifm of Matter. That as any one Body, or part of Matter, cannot be the Caufe of its own Gravity: fo no more can it ever poffibly be the Caufe of the Gravity of another Body, or part of Matter. That neither the Earth's diurnal Revolution upon its Axis: nor any magnetick EfGuvia of the Earth: nor the Air, or Atmolphere which environs the Earth: nor the Rither, or Materia fubtilis of 


\section{Part I. of the Earth.}

the Cartefians, in what manner foever moved or agitated: (all which have been propofed by feveral Learned Men as the Caufes of Gravity) nor any other Fluid or Matter whatever, can of it felf produce fuch an Effect as is that of the Gravity of Bodies. That it does not proceed from the Efficiency of any fuch contingent and unftable Agents, but ftands on a Bafis more firm and ftedfaft, being intirely owing to the direct Concourfe of the Power of the Author of Nature, immediately in his hand, and the main Engine whereby this ftupendous Fabrick of the Univerfe is managed and fupported: the prime Hinge whereon the whole frame of Nature moves: and is principally concerned, if not the fole Efficient in the moft remarkable Phornomens of the Natural World; which, fhould Gravity once ceafe, or be withdrawn, would inftantly thiver into Millions of Atoms, and relapfe into its primitive Confufion. That the common Center of Gravity in the terraqueous Globe is fteady, immovable, and not liable to any accidental Tranfpofition, nor hath it ever fhifted or changed its Station. And that there is no declina-

$$
\text { E } 3 \text { tion }
$$


tion of Latitude: nor variation of the Elevation of the Pole; notwithftanding what fome Learned Men have afferted.

What concerns the raifing of new Mountains: Deterrations, or the Devolution of Earth down upon the Valleys, from the Hills and higher Grounds: and Inands torn off from the main Continent by Earthquakes, or by the furious and impetuous infults of the Sea ; thefe, I fay, will fall more properly under our Confideration on ano*Part 2. ther Occafion*. And for the Mutaand Part 5. tions of leffer moment, which fome have fancied to have happened within this Interval, I mean, for the laft four thoufand Years fince the Deluge, I chufe rarher to pals them over at prefent, than to crowd and encumber this Thort Trace with the account of them.

I muft needs freely own, that when I firfe directed my Thoughts this way, "twas matter of real Admiration to me, to find that a Belief of fo many, and fuch great Alterations in the Earth, had gained fo large footing, and made good its ground fo many Ages, in the World; there being not the leaft figns nor footiteps of any fuch thing upon the 


\section{Part I.}

the face of the whole Earth : no tolerable Foundation for fuch a Belief either in Nature or Hiftory. But I foon faw very well, that the Moderns generally entertained it meerly upon the Credit and Tradition of the Ancients, and that without due Examination, or Enquiry into the Truth and Probability of it; and 'twas not long e're I difcovered what it was that fo generally milled the Ancients into thefe Miftakes. But of that more by and by.

Thofe ancient Pagan Writers were indeed very much excufable as to this matter. Philofophy was then again in its Infancy : there remaining but few marks of the old Tradition, and thore much obliterated and defaced by Time; fo that they had only dark and faint Idea's, narrow and fcanty Conceptions, of Providence : and were ignorant of its Intentions, and of the methods of its Conduct in the Government and Prefervation of the Natural World. They wanted a longer Experience of thefe things: a larger ftock of Obfervations, and Records of the ftate of the Earth before their times; having, as things then ftood, nothing to affift them in their Enquiries befides their

$$
\text { E } 4
$$

own 
own Gueffes and Fancy. For their Progenitors, and thofe who had lived in the earlier Ages, were almoft entirely taken up with Bufinefs of another kind. That fatal Calamity, the Deluge, had wrought fuch a Change, * part 2. *that they beheld every where a new face of things: and the Earth did not then teem forth its Encreale, as formerly, of its own accord, but required Culture, and the Affiftance of their Hands, much more than before it did. The provifion of Bread for Food: Clothing to ward off the Injury and Inclemency of the Air : and other like Employs for the Comfort and Support of Life, being of indifpenfible necelfity, were to be firt look'd after; and thefe Employs, being then for the moft part new to them, and fuch as they were unskill'd in, were alone enough to take up the greateft part of their time. The methods they ufed of Agriculture, and other Arts of like importance, were fo aukward and tedious, as to afford them little leifure for Works of the Brain, for Hiltory, or Contemplations of that nature. And till better Experience had led their Polterity to the Improvements of Arrs: 


\section{Part I. of the Earth.}

till the Plow, and other ufeful Inftruments, were found out: and they had learn'd more compendious and expeditious ways of difpatching thofe Affairs, whereby they fhorned their Labours, and fo gained time, there was no fbem of Learning, or Matters of Speculation among them; and we hear little or nothing of Writing, nay 'twas a very confiderable time before Letters themfelves were found out. I know very well, there are fome who talk of Letters before the Deluge; but that is a matter of meer Conjecture, and I think nothing can be peremptorily determined either the one way or the other; though I thall fhew, that 'tis highly probable they had none. Be that how it will, I fhall plainly make out, that the Ages which next fucceeded the Deluge had none; fo far from it, that they knew nothing at all of them; and the firft Writing they ufed was only the fimple Pictures, and Gravings of the things they would reprefent, Beafts, Birds, and the like; which way of Expreffion was afterwards called Hieroglyphick. But this fell into difufe, when Letters were afterwards difcovered; they being, in all refpccts, a 
far more excellent and noble Invention. We fee therefore that there were feveral Reafons why thofe early Ages could not tranfmit Accounts of the ftate of the Earth and of thefe Marine Bodies, in their times, down to the fucceeding Generations. So that thefe having little more to truft to than their own Imagination, and no furer a Guide in their Reafonings about the fe things than bare Conjecture, 'twas no wonder that they fell into grofs and palpable Miftakes concerning them.

Nor much more wonder is it that an Epicurus: one who could ever efpoufe a Notion fo enormouly abfurd and fenfelefs, as that the World was framed by Chance: that this vaft, regular, and moft ftupendous Pile was owing to no higher a Principle than a fortuitous Congrefs of Atoms: and that either there was no God at all, or, which is much the fame thing, that he was an impotent and lazy Be. ing, and wholly without concern for the Affairs of this lower World: I fay, 'tis in no wife ftrange that fuch a one fhould believe, as he did, that things were blindly lhuffled and hurled about in the World: that the Elements were 


\section{Part I. of the Earth.}

at conftant Strife and War with each other: that in fome places, the Sea invaded the Land: in others, the Land got ground of the Sea : that all Nature was in an Hurry and Tumult: and that as the World was firft made, fo fhould it be again diffolved and defroyed, by Chance : that it had alreaready made large Advances that way, being infirm and worn with Age, thattered and crazy, and would in time dwindle and fall back again into its original Chaos.

Did Gravity, the Inclination of Bodies towards the fame common Center, to which Inclination they owe their refpective order, and fite in regard of each other, very many of their Motions and Actions, and in a great meafure, their prefent Conftitution : did this, I fay, happen from fo contingent, precarious, and inconftant Caufes as many have believed : or did it ftand upon fo ticklifh and tottering a Foundation as fome Mens fancy hath placed it, 'twould be no wonder fhould it frequently vary: its Center fwerve and hift, upon every turn: and that there thould enfue thereupon, not only fuch Motions and Alterations of the 
Bounds of the Sea as they imagine; but likewife many other, and not lefs pernicious, Perturbations of the courfe of even univerfal Nature.

Or was the Univerfe left to its own Conduct and Management : the whole Mafs of created Matter to its proper Difpofition and Tendency: were there no reftraint of Bounds to the Earth, nor Curb to the fury of the Ocean : was there not One who had fet bars and doors to it, and Said bitberto Sbalt thors conse, but no farther, and here Ball thy proid $W$ aves be ftaid; then indeed might we well expect fuch Viciffitudes and Confufions of things : fuch Juftlings and Clafhings in Nature: fuch Depredations, and Changes of Sea and Land.

But if the fame mighty Power, which in the beginning produced this vaft Syftem of Bodies out of Nothing, and difpofed and ranged them into the moft excellent and beautiful order we now behold: which at firft framed an Earth of a Conftitution futable to the innocent ftate of its primitive Inhabitants: and afterwards when Man had degenerated, and quitted that Innocence, altered that Conftitution of the 


\section{Part I. of the Earth.}

Earth, by means of the Deluge*, and " Part 2. reduced it to the Condition 'tis now conf:a. \& in, thereby adapting it more nearly to the prefent Exigencies of things, to the laps'd and frail ftate of humane $\mathrm{Na}$ ture: If that fame Power be yet at the Helm: if it prefide in the Government of the Natural World : and hath ftill the fame peculiar Care of Mankind, and, for their fake, of the Earth, as heretofore, (all which thall be evidently made out:) then may we very reafonably conclude 'twill alfo continue to preferve this Earth, to be a convenient Habitation for the future Races of Mankind, and to furnilh forth all things neceffary for their ufe, Animals, Vegetables, and Minerals, as long as Mankind it felf thall endure; that is, till the Defign and Reafon of its Prefervation fhall ceafe; and till then, fo fteady are the Purpofes of Almighty Wifdom, fo firm eftablifh'd, and conftant the Laws, whereby it fupports and rules the Univerfe; the Earth, Sea, and all natural things will continue in the ftate wherein they now are, without the leaft Eenefcence or Decay, without jarring, diforder, or invalion of one another, without in- 
verfion or variation of the ordinary $\mathrm{Pe}$ riods, Revolutions, and Succeffions of things: and we have the higheft fecurity imaginable, that $W$ bile the Earth remaineth, Seed-time and Harveft, and Cold and Heat, and Summer and Winter, and Day and Night fball not ceafe.

And whatever may be urged in behalf of the Ancients, I cannot well fee, I confefs, what can be faid for the later Authors, who have embrac'd the fame Tenets, more than that thefe Learned Men took up thofe Tenets on truft, their over-great deference to the Dictates of Antiquity betraying them into a perfuation of fuch Changes in the Earth. I have given my Reafons above why I cannot think the Ancients competent Judges in this Cafe. We have, at this time of day, better and more certain means of Information than they had; and therefore it were to have been wifh'd, that thefe Gentlemen had not thus obfequioufly followed them, but gone another way to work. It would certainly have been much better, had they taken the pains to have look'd a little into Matter of $F_{a c t}$ : had they confulted Hiftory and Geography, in order duely to acquaint them: 


\section{Part I. of the Eartb.}

themfelves with the paft and prefent ftate of the terraqueous Globe; and not to have pafs'd Sentence till they had firft compared the moft ancient Defcriptions of Countries with the Countries themfelves as now they fiand. Nay, had they but read and attended to the Accounts which the very Authors, from whom they borrow thefe Opinions, have left us, they might have difcovered, even from them, the Errors and Overfights of their Authors: and have learn'd, that the Face of Sea and Land is the very fame at this day that it was when thofe Accounts were compiled: and that the Globe hath not fuftained any confiderable Alterations, either in the whole, or any of its $\boldsymbol{P}$ arts, in all this time.

Thofe who can content themfelves with a Superficial View of Things: who are fatisfied with contemplating them in grofs: and can acquiefce in a general, and lefs nice Examination of them: whofe Thoughts are narrow and bounded: and their Profpects of Nature fcanty, and by piecemeal, muft needs make very fhort and defective Judgments, and, oftentimes very erroneous, and wide of truth. Some fanciful 
fanciful Men have expected nothing but Confulion and Ruin from thofe very means whereby both that and this is moft effectually prevented and avoided. One imagines that the terreftrial Matter, which is fhowered down along with Rain, enlarges the Bulk of the Earth, and that it will in time bury, and lay all things under ground. Another, on the contrary, fancies that the Earth will ere long all be wafh'd away by Rains, and borne down into the Sea by Rivers; and, its Chanel being thereby quite filled up, the Waters of the Ocean turned forth to overwhelm the dry Land. Whereas by this Diftribution of Matter, continual Provifion is every where made for the fupply of Bodies: the juft ftate of Sea and Land preferved, and the Bounds of each fecured; quite contrary to the prepofterous Reafonings of thofe Men, who expected fo different a Refult of thefe things. And hould this Circulation (from which they dreaded thofe difmal Confequences) once ceafe, the Formation of Bodies would be immediately at an end: and Nature at a perfect ftand. But I am aware that I tranfgrefs: and that this is a Prolixity not 


\section{Part I. of the Earth.}

not allowable in a Treatife of this nature; wherefore I Tháll conclude, after I have performed mý Promife of difcovering what it was which led the ancient Hiftorians, Geographers, and others, fo generally into a belief of thefe frequent Changes betwixt Sea and Land; and 'twas this.

They obferved, almoft wherever they caft their eyes, vaft multitudes of Sea-fhells, at Land, in their Fields, and even at very great diftance from any Sea. This, Eratafthenes, Herodotus, Xantbus Lydus, Strabo, Paufanias, Pomponins Mela, Theophraftus, Strato the Philofopher, Plutarch; and others of them affure us. They found them upon the Hills, as well as in the Valleys and Plains : they obferved that they were immerfed in the Mafs of the Stone of their Rocks, Quarries, and Mines, in the farne manner as they are at this day found in all known Parts of the World.

Nay in thofe Elder Times, and which were fo much nearer to the Deluge than ours are, they found thefe Marine Bodies more frequently, and in much greater plenty than we now do; and moft, if not all of them, frefl, 
entire, and firm. The whole cruftaceous kind, and the lighter ones of the teftaceous, which together would be a vaft number, fubfiding laft, fell up" pag. 29, on the Surface of the Earth; * whilft \&c. Jupra, the heavier,which fettled down before, Conf. 3 . were entombed in the bowels of it. Thofe therefore mult then lye everywhere ftrewed upon the ground; whereas now very few, if any, of them onf.pag. appear; $\uparrow$ the Shells which we find at * and prefent upon the face of the Earth beant. 3. ing principally of the heavier forts, which were at firft lodged within it, and fince difclofed and turked out, by f Part 5. what means we fhall fee hereafter $\|$. conf. 4. And indeed, 'tis not conceivable how the generality of them could endure fo many Hundreds of Years as have fince paft : how they could lye fo long expofed to the Air, Weather, and other Injuries, without vaft numbers of them, and efpecially the finer and tenderer Species, being, long e're this, perifh'd and rotten, fome of them quite diffolved and vanifh'd, and the reft fo damaged, many of them, and altered by time, as not to appear the things they then were, and fo create a doubt amongft fome of us whether they are really Shells or not. 


\section{Part I. of the Earth.}

This was a Scruple that never entered into their Heads. The Shells, being then fair, found, and free from decay, were fo exaclly like thofe they faw lying upon their Shores, that they never made any queltion but that they were the Exuvie of Shell-filh, and that they once belonged all to the Sea. But the Difficulty was how they came thither, and by what means they could ever arrive to places oftentimes fo remote from the Ocean.

The Ages that went before knew well enough how thefe Marine Bodies were brought thither. But fuch were the Anxieties and Diftreffes of the then again infant World: fo inceffant their Occupations about Provifion for Food, Rayment, and the like, that (even after Letters were difcovered) there was little leifure to commit any thing to Writing; and, for want thereof, the memory of this extraordinary Accident was in great meafure worn out and loft. 'Tis true there was a general and loud Rumour amongft them of a mighty Deluge of Water that had drowned all Mankind except only a very few Perfons. But there had alfo happened very terrible Inundations of later date, 
and which were nearer to the Times when thefe Authors lived. Such was that which overflowed Attica in the days of Ogyges: and that which drowned Theffaly in Deucalion's time. Thefe made cruel Havock and Devaftation amongft them: their own native Country, Greece, was the Theatre whereon thefe Tragedies were acted: and their Progenitors had feen and felt their Fury. And thefe happening nearer home, and their Effects being frefh, and in all Mens mouths, they made fo fenfible and lafting Impreffions upon their Minds, that the old great Deluge was eclipfed by that means, its Tradition mightily obfcured, and the Circumftances of it fo interwoven and confounded with thofe of thefe later Deluges, that 'twas e'en dwindled into nothing, and almoft buried in the Relations of thofe Inundations.

In their Enquiries therefore into this Matter, fcarcely a Man of them thought, or fo much as dream'd, of the Univerfal Deluge. They concluded indeed unanimouly, that the Sea had been there, wherever they met with any of thefe Shells, and that it had left them 


\section{Part 1. of the Earth.}

them behind. And fo far they were in the right: this was an Inference rational and natural enough. But when they began to reafon about the means how the Sea got thither, and a way back again, there they were perfectly in the dark; and, both Tradition and Philofophy failing them, they had recourfe to Shifts, and to the beft Conjectures they could think of ; concluding that it was either forced forth, as in particular Inundations, fuch as thofe lately mentioned: or that thofe Parts, where they found the Shells, had been formerly in the Poffeffion of the Sea, and the place of its natural Refidence, which it had fince quitted and deferted.

Upon this they began to feek out by what means, moft probably, the Sea might have been difpoffeft of thofe Parts, and conftrained to move into other Quarters. And if 'twas an Ifland where they found the Shells, they ftraitways concluded that the whole Inland lay originally at the bottom of the Sea: and that 'twas either hoifted up by fome Vapour from beneath: or that the Water of the Sea, which formerly cover'd it, was in time exhaled,

$$
\mathrm{F}_{3} \text { and }
$$


and dryed up by the Sun, the Land thereby laid bare, and thefe Shells brought to light. But if 'twas in any part of the Continent where they found the Shells, they concluded that the Sea had been extruded and driven off by the Mud that was continually brought down by the Rivers of thofe parts.

That I may not be over-tedious here, I will only add, that I thall clearly thew, from plain Paffages of their own Writings yet extant, that'twas meerly the finding thefe Sea-fhells at Land that occafioned this Stir, and raifed all this Duft amongft the Ancients; and upon which principally they grounded their Belief of the Vicifirtudes and Changes of Sea and Land, wherew ith their Writings are fo filled. But how little reafon they had for it: and how far thofe have been over-feen who have followed them herein, hath been intimated already, and will appear farther from the following part of this Efay, to the Account of which I now haften. 


\section{Part II. of the Earth.}

\section{P A R T II.}

Concerning the Univerfal Deluge. That the fe Marine Bodies were then left at Land. The Effects it bad upon the Earth.

THE Confectaries of the former part of this Difcourfe are all negative; that being only introductory, and ferving but to clear the way to this fecond part : to free the Enquiry from the Perplexities that fome Undertakers have encumber'd it withall: and to fet afide the falle Lights they ufed in queft of the Agent which tranfpofed thefe Sea-fhells to Land.

Having therefore difcharged my hands of that Task, and, from Obfervation of the prefent ftate of the Earth, and of the fite and condition of the Marine Bodies which are lodged within and upon it, thewn that they could 
not poffibly be repofed in that manner by particular Inundations : by the Seas receding and fhifting from place to place: nor by any of the other means there propofed: I pafs next on to fearch out the true means : and to difcover the Agent that did actually bring them forth, and difpofed them into thé Method and Order wherein we now find them. To which purpofe I have recourfe again to the Obfervations; for by their Affiftance this Matter may be rightly and fully adjufted. So that I fhall only proceed, as hitherto, to make Inferences from them; which Inferences, in this Part are all affirmative. Of thefe, the firft is,

I. That thefe Marine Bodies were "corfer. burn forth * of the Sea by the Univerpart 3. Fal Deluge : and that, upon the return

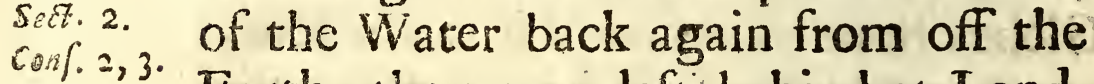

Earth, they were left behind at Land.

This is a Propofition of fome weight: and confequence; upon which Account I thall be fomewhat prolix and particular in the Eftablifhment of it : careful and exact in conferring every Circumftance of thefe Marine Bodies, to fee how they fquare with it: and thall not difmifs it till I have evinced 


\section{Part II. of the Earth.}

that thofe which I preft, in the precedent Part, as Objections againft the feveral ways there propounded, all fall in here, and are the cleareft and moft convincing Arguments of the truth hereof: that this, and this alone, does naturally and eafily accoune for all thofe Circumftances : and fairly takes off all Difficulties. Which Difficulties I propofe at large, and particularly thofe which have of late been urged, by fome Learned Men, as proofs that thefe Bodies were net left behind by the Deluge; thewing of how little Validity they are.

Which being difpatch'd, I return back to my Obfervations; and proceed upon them to reprefent the Effects that the Deluge had upon the Earth, and the Alterations that it wrought in the Globe; fome whereof were indeed very extraordinary. Thefe I diftribute into two Claffes; the first of which will contain tho/e that are only probable, and of which we have fone reafonable Intimations, but not an abfolure and demonftrative Certainty, the Proofs whereon they depend being more remote. And thefe I thall wholly wave at prefent, and not crowd 
this thorter Treatife with the Relation of them, referving that room for thofe of the Jecond Clats, which are thofe whereof we have a plain and undeniable Certainty : thofe which flow directly and immediately from the $\mathrm{Ob}$ fervations: and whioh are fo evident, that'tis impoffible thefe Marine Bodies could have been any ways lodged in fuch manner, and to fo great depths, in the Beds of Stone, Marble, Chall, and the reft, had not thefe Alterations all happened. Namely,

2.

That during the time of the Deluge, whilft the Water was out upon, and covered the Terreftrial Globe, All the Stone and Marble of the Antediluvian Earth : all the Metalls of it : all Mineral Concretions: and, in a word, all Folfils whatever that had before obtained any Solidity, were totally diffolved, and their conftituent Corpufcles all disjoyned, their Cohrefion perfectly ceafing. That the faid Corpufcles of thefe folid Foffils, together with the Corpufcles of thofe which were not before folid, fuch as Sand, Earth, and the like: as alfo all Animal Bodies, and parts of Animals, Bones, Teeth, Shells: Vegetables, and 


\section{Part II. of the Earih.}

parts of Vegetables, Trees, Shrubs, Herbs : and, to be hort, all Bodies whatfoever that were either upon the Earth, or that conffitured the Mafs of it, if not quite down to the Abyfs ${ }^{*}$, * Vid. yet at leaft to the greateft depth we ${ }_{\text {Seet }}^{\text {Part }} 3$. ever dig: I fay all thefe were affumed corfectit ro up promifcuoufly into the Water, and fuftained in it, in fuch manner that the Water, and Bodies in it, together made up one common confufed Mafs.

That at length all the Mafs that 3 . was thus borne up in the Water, was again precipitated and fubfided towards the bottom. That this Subfidence happened generally, and as near as poffibly could be expected in fo great a Confufion, according to the Laws of Gravity $\uparrow$ : that Matter, Bo + Confers: dy, or Bodies, which had the greateft p. 29. \&c. quantity or degree of Gravity, fubfiding firft in order, and falling loweft: that which had the next, or a ftill leffer degree of Gravity, fubfiding next after, and fettling upon the precedent : and fo on in their feveral Courfes; that which had the leaft Gravity finking not down till laft of all, fettling at the Surface of the Sediment, and covering all the reft. That the 
Matter, fubfiding thus, formed the Strata of Stone, of Marble, of Cole, of Earth, and the reft; of which Stra$t a$, lying one upon another, the Terreftrial Globe, or at leaft as much of it as is ever difplayed to view, doth mainly confift. That the Strata being arranged in this order meerly by the difparity of the Matter, of which each confifted, as to Gravity, that Matter which was heavieft defcending firft, and all that had the fame degree of Gravity fubfiding at the fame time : and ihere being Bodies of quite different Kinds, Natures, and Conftitutions, that are nearly of the fame fpecifick Gravity, it thence happened that Bodies of quite different kinds fubfided at the fame inftant, fell together into, and compofed the fame Stratum. That for this reafon the Shells of thofe Cockles, Efcalops, Perewinkles, and the reft, which have a greater degree of Gravity, were enclofed and lodged in the Strata of Stone, Marble, and the heavier kinds of Terreftrial Matter : the lighter Shells not finking down till afterwards, and to falling amongft the lighter Matter, fuch as Chalk, and the like, in all fuch parts 


\section{Part II. of the Earth.}

of the Mafs where there happened to be any confiderable quantity of Chalk, or other Matter lighter than Stone; but where there was none, the faid Shells fell upon, or near unto, the Surface : and that accordingly we now find the lighter kinds of Shells, fuch as thofe of the Echini, and the like, very plentifully in Chalk, but of the heavier kinds fcarcely one ever appears; thefe fubfiding fooner, and fo fettling deeper, and beneath the Strata of Chalk. That Humane Bodies, the Bodies of Quadrupeds, and other LandAnimals, of Birds, of Fithes, both of the Cartilaginous, Squamofe, and Cruftaceous kinds; the Bones, Teeth, Horns, and other parts of Beafts, and of Finhes: the Shells of Land-Snails: and the Shells of thofe River and Sea Shell-Fifh that were lighter than Chalk or. Trees, Shrubs, and all other Vegetables, and the Seeds of them : and that peculiar Terreftrial Matter whereof thefe confift, and out of which they are all formed: I fay all thefe (except fome Mineral or Metallick Matter happened to have been affix'd to any of them *, whilf they were fuftained ${ }^{*} P_{\text {art }} 4$. together in the Water, fo as to aug- 
ment the weight of them) being, bulk for bulk, lighter than Sand, Marl, Chalk, or the other ordinary Matter of the Globe, were not precipitated till the laft, and fo lay above all the former, conftituting the fupreme or outmoft Stratum of the Globe. That the $e$ being thus lodged upon the reft, and confequently more nearly expofed to the Air, Weather, and other Injuries; the Bodies of the Animals would fuddenly corrupt and rot : the Bones, Teeth, and Shells, would likewife all rot in time, except thofe which were fecured by the extraordinary Strength and Firmnefs of their Parts, or which happened to be lodged in fuch places where there was great plenty of bituminous or other like Matter to preferve, and, as it were, embalm them : that the Trees would in time alfo decay and rot, unlefs fuch as chanced to be repofed in, and fecured by the fame kind of Matter: that the other more tender Vegetables, Shrubs, and Herbs, would rot likewife and decay: But the Seeds of all kinds of Vegetables, being by this means repofed, and, as it were, planted near the Surface of the Earth, in a convenient and natural $\mathrm{Soil}_{3}$ 
Part II. of the Eartb.

Soil, amongft Matter proper for the Formation of Vegetables, would germinate, grow up, and replenifh the face of the Earth : And that vegetative terreftrial Matter, that fell, along with thefe, into this uppermoft Stratum, and of which principally it confifts, hath been ever fince, and will continue to be, the ftanding fund and promptuary out of which is derived the Matter of all Animal and Vegetable Bodies, and whereinto, at the Diffolution of thofe Bodies, that Matter is reftored back again fucceffively for the Conftitution and Formation of others.

That the Strata of Marble, of Stone, and of all other folid Matter, attained their Solidity, as foon as the Sand, or other Matter whereof they confift, was arrived at the bottom, and well fettled there: And that all thofe Strata which are folid at this day, have been fo ever fince that time.

That the faid Strata, whether of Stone, of Chalk, of Cole, of Earth, or whatever other Matter they confifted of, lying thus each upon other, were all originally parallel : that they were plain, eaven, and regular; and the Surface of the Earth likewife eaven 
and fpherical: that they were continuous, and not interrupted, or broken: and that the whole Mafs of the Water lay then above them all, and conftituted a fluid Sphere environing the Globe.

6. That after fome time the Strata were broken, on all fides of the Globe: that they were diflocated, and their Situation varied, being elevated in fome places, and depreffed in others.

7. That the Agent, or force, which effected this Difruption and Diflocation of the Strata, was feated within the Earth.

8. That all the Irregularities and Inequalities of the Terreftrial Globe were caufed by this means : date their Original from this Difruption, and are all entirely owing unto it. That the natural Grotto's in Rocks, and thofe Incervals of the Strata, which, in my Obfervations, I call the Perpendicular Fif ${ }_{\text {ures, }}$ are nothing but thefe Interruptions or Breaches of the Strata. That the more eminent Parts of the Earth, Mountains and Rucks, are only the Elevations of the Strata; thefe, wherever they were folid, rearing againt and fupporting each other in 


\section{Part II. of the Earth.}

the pofture whereinto they were put by the burfting or breaking up of the Sphere of Earth \|: and not falling " conf. down again, nor returning to their conf.s. former and more level fite, as did the fupra. Strata of Earth, and other Matter that was not folid, and had no Strata of Stone, or other confiftent Matter, interpofed, amongft their Strata, underneath, to uphold them in the pofture they were then raifed into. For which reafon'tis, that Countries which abound with Stone, Marble, or other folid Matter, are uneaven and mountainous: and that thofe which afford none of thefe, but confift of Clay, Gravel, and the like, without any Stone $\&$ c. interpofed, are more champaign, plain, and level. That the lower parts of the Earth, Vallies, the Chanel of the Sea, and the reft, are nothing but Depreffions of the Strata. That Iflands were formed and diftinguifhed by the Depreffion or finking down of the Strata lying betwixt each of them, and betwixt them and the Continent. In one word, that the whole terraqueous Globe was, by this means, at the time of the Deluge, put into the Condition that we now behold.

G Here 
Here was, we fee, a mighty Revo. lution: and that attended with Accidents very ftrange and amazing: the moft horrible and portentous Cataftrophe that Nature ever yet faw : an elegant, orderly, and habitable Earth quite unhinged, fhattered all to pieces, and turned into an heap of ruins : Convulfions fo exorbitane and unruly : a Change fo exceeding great and violent, that the very Reprefentation alone is enough to itartle and thock a Man. In truth the thing, at firft, appeared fo wonderful and furprizing to me, that I muit confefs I was for fome time at a ftand; nor could I bring over my Reafon to affent, untill, by a deliberate and careful Examination of all Circumfrances of thefe Marine Bodies, I was abundantly convinced that they could not have come into thofe Circumftances by any other means than fuch a Diffolution of the Earth, and Confufion of things. And were it not that the Obfervations, made in fo many, and thofe fo diftant, places, and repeated fo often with the moft fcrupulous and diffident Circumfpection, did fo eftablin and afcertain the thing, as not to leave any room for Conteft or Doubr, 


\section{Part II. of the Earth.}

Doubt, I could fcarcely ever have credited it.

And though the whole Series of this extraordinary Turn may feem at firft view to exhibit nothing but Tumult and Diforder : nothing but hurry, jarring, and diftraction of things : though it may carry along with it fome flight thew that 'twas managed blindly and at random: yet if we draw fomewhat nearer, and take a clofer profpect of it: if we look into its retired Movements, and more fecret and latent Springs, we may there trace out a fteady Hand, producing good out of evil: the moft confummate and abfolute Order and Beauty, out of the higheft Confufion and Deformity : acting with the moft exquifite Contrivance and Wifdom: attending vigilantly throughout the whole Courfe of this grand Affair, and directing all the feveral Steps and Periods of it to an End, and that a molt noble and excellent one; no lefs than the Happinefs of the whole race of Mankind : the Benefit, and univerfal Good, of all the many Generations of Men which were to come after: which were to inhabit this Earth, thus moduled anew, thus fuited to their G 2 But 
prefent Condition and Neceffities.

But the Prefidence of that mighty Power in this Revolution: its particular Agency and Concern therein: and its Purpofe and Defign in the feveral Accidents of it, will more evidently appear, when I fhall have proved,

That, altho' one Intention of the Deluge was to inflict a deferved $\mathrm{Pu}-$ nifhment upon that Race of Men, yet it was not folely levelled againft Mankind, but principally againft the Earth that then was; with defign to deftroy. and alter that Conftitution of it, which was apparently calculated and contrived for a ftate of Innocence : to fafhion it afrelh, and give it a Conftitution more nearly accommodated to the prefent Frailties of its Inhabitants.

That the faid Farth, though not indifferently and alike fertil in all parts of it, was yet generally much more fertil than ours is. That the exteriour Stratum or Surface of it, confifted entirely of a kind of terreftrial Matter proper for the Nourifhment and Formation of Plants, and this in great Pienty and Purity; being little, or not at all, entangled with an Intermixture of meer Mineral Matter that was unfit 


\section{Part II. of the Earti.}

for Vegetation. That its Soil was more lixuriant, and teemed forth its Productions in far greater plenty and abundance than the prefent Earth does. That the Plough was then of no ufe, and not invented till after the Deluge; that Earth requiring little or no Care or Culture; but yeilding its encreafe freely, and without any confiderable Labour and Toil, or affintance of Humane Induftry; by this means allowing Mankind that time, which muft otherwife have been fpent in Agriculture, Plowing, Sowing, and the like, to far more divine and noble Ufes : to Purpofes more agreeable to the Defign of their Creation; there being no hazard, whilft they continued in that ftate of Perfection, of their abufing this Plenty, or perverting it to any other end than the fuftenarice of $\mathrm{Na}$ ture, and the neceffary fupport of Life.

That when Man was fallen, and had abandoned his primitive Innocence, the Cafe was much altered, and a far different Scene of Things prefented ; that generous Vertue, mafculine Bravery; and prudent Circumfpectionf

$$
G_{3} \text { which }
$$


which he was before Mafter of, now deferted him, together with that Innocence which was the Bafis and Suppore of all: and a ftrange imbecility immediately feized and laid hold of him: he became pufillanimous, and was eafily ruffled with every little Paffion within: fupine, and as openly expofed to any Temptation or Alfault from without. And now thefe exuberant Productions of the Earth became a continual Decoy and Snare unto him: they only excited and fomented his Lufts, and miniftred plentiful Fewel to his Vices and Luxury; and the Earth requiring little or no Tillage, there was little occafion for Labour; fo that almoft his whole time lay upon his hands, and gave him leifure to contrive, and full fwing to purfue his Follies; by which means he was laid open to all manner of Pravity, Corruption, and Enormity; and we need not be much furprized to hear That the wickednefs of Man was great in the Earth, and that every imagination of the, thonghts of Gen. vi. s. bis heart was only evil continually * * nor more, that that Generation of Men was more particularly addicted to Intempe- 


\section{Part II. of the Earth.}

temperance, Senfuality, and Unchaftity : that they fpent their time in Gluttony, in Eating and Drinking, in Luft and Wantonnefs, or, as the facred Writer cleanly and modeftly expreffes it, in marrying, and giving in marriage $\|$,$\| Matth.$ and this without Difcretion or Decen- xxiv. ${ }^{88}$. cy : without regard to Age or Affinity: but promifcuoully, and with no better a Guide than the Impulfes of a brutal Appetite, They took them Wives of all which they chofe $e^{*}$; Plenty and Abun- * Gen.vio. dance, Idlenéfs and Eafe, fo naturally cherifhing and promoting thofe particular Vices: nor laftly, that the Apoftacy was fo great, the Infection fo univerfal: that the Earth was filled with violence, and that all fle $b$ bad corrupted bis way $\uparrow$; the Caufe of this Corrupti-' + Gen. vis on, the Fertility of that Earth, being 11, 12。 fo univerfal, to diffufive and epidemical. And indeed, 'twould be very hard to affign any other fingle Caufe, befides this, that could ever poffibly have had forfpreading and general an effeet as this had. The Pravity of hura ane Nature is not, I fear, lefs thgle it was then: The Paftions of Mer are yet as exorbitant, and their Inclinations as vicious: Men have been wicked fince

$$
\text { G } 4 \text { the }
$$


the Deluge : they are fo ftill: and will be fo, but not univerfally; there are now bounds fet to the Contagion, and 'tis reftrained by removing the main caufe of it ; but there, the Venom manifefted it felf on all hands: fpread far and near: and fcarcely ftop'd till 'twas infinuated into the whole mafs of Mankind, and the World was little better than a common fold of Phrenticks and Bedlams.

That to reclaim and retrieve the World out of this wretched and forlorn ftate, the common Father and Benefactor of Mankind feafonably interpofed his hand: and refcued miferable Man out of the grofs Stupidity and Senfuality whereinto he was thus unfortunately plunged. And this he did partlye by tying up his hands, and hortning the power of finning: checking him, in the Career of his Follies, by Difeafes and Pains: and fetting Dearh, the King of Terrorsy which before ftood aloof off, and at the longryiftance of eight or nine hun-

" confer dred Yearns now much nearer to his

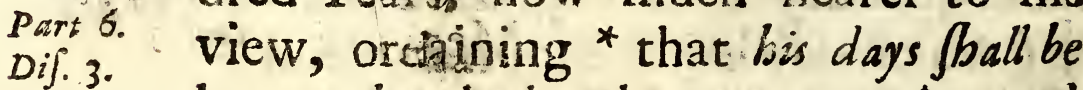
t Gen. but ars bundred and twenty years $\uparrow:$ and 6. 3. partly by removing the Temptation, and 
and caufe of the Sin :

by deftroying * that Earth which had furnifh'd forth Maintenance in fuch ftore unto it: by changing that Conftitution of it, and rendring it more agreeable to the laps'd and frail ftate of Mankind. That this Change was not wrought by altering either the form of the Earth, or its Pofition in refpect of the Sun, as was not long ago furmifed by a very Learned Man $\uparrow$, but by diffolving $\|$ it : by reducing all the Matter of it to its firft con-
* Cen. vi I 3. And bebold I will DESTROY them with THE EARTH. And again, at the Covenant made with Noab, after the Deluge, more diftinctly Gen. ix. II. Neither fhall all fles be cut off any more by the waters of a flood: neither Sall there any more be $A$ FLOOD TO DESTROY THE EARTH; the latter part whereof is render'd fomewhat more exprefly by the Septuagint $x_{y}^{\prime}$ \&े हैंt

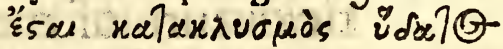
xaीac日eigas $\Pi A^{2} \Sigma A N$ tho yliv. i. e. And there Shall not be any more a Deluge of Water to deftroy the WHOLE E.ARTH. And the vulg. Lat. Neque erit deinceps Diluvium diffipans terram, i. e. Neither thall there be hereafter a Deluge to diffinate [ or diffolve] the Earth. And of this Difjolutiose of the Earth there was a Tradition amongtt the Ancients, both Fews and Gentiles. ftituent Principles: by mingling, and $+D r$. Burconfounding them: the Vegetative net. Theowith mineral Matter, and the different Eartb. kinds of mineral Matter with each $\|$ Vid.

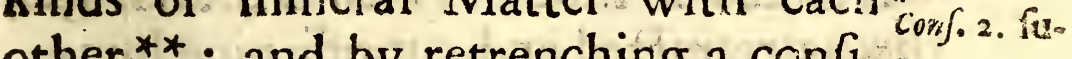
other ${ }^{* *}$ : and by retrenching a confi- pra. derable quantity of the vegetable Mat- "tart.4. ter, (which lay in fuch plenty and purity at the surface of the Antedila. vian Earth, and rendred it fo exube. 
rantly fruitful) and precipitating it, \#vid. conf. (at the time of the fubfidence $\|$ of the 3. Jupras. general Mafs of Earth and other Bot dies, which were before raifed up in to the Water) to fuch a depth as to bury it, leaving only fo much of it near the Surface as might juft fufficiently fatisfie the Wants of humane $\mathrm{Na}$ ture, but little or no more; and evén that not pure, not free from the intermixture of meer fteril mineral Matter, and fuch as is in no wife fit for the Nutrition of Vegetables; but fo that it Thould require Induftry and Labotir to excite it, and not yeild a competent Crop without Tillage and Manure. That by this means, a great part of that time, which the Inhabitants of the former Earth had to fpare, and whereof they made fo ill ufe, was employed, and taken up in Digging and Plowing, in making provifion for bread, and for the Neceffities of Life: and the Excefs of Fertility, which con tributed fo much to their Mifcarriages, was retracted and cut off.

That had the Deluge been aimed only at Mankind: and its utmoft defign meerly to punifh that Generation, and thereby to deterr Pofterity from the 


\section{Pare II. of the Earth.}

like Offences; this might have been brought about by means much more compendious, and obvious too, and yet equally terrifying and exemplary. Mankind, I fay, might have been taken off at a far cheaper rate: without this ranfacking of Nature, and turning all things topfie-turvy: without this battering of the Earth, and unhinging the whole frame of the Globe. The Bufinefs might have been done as effeCtually by Wars; the Heart of every Man of them was in the hand of God, and he could eafily have made them Executioners of bis Wrath upon one another. He had the command of $\mathrm{Fa}$ mine, of Peftilence, and a thoufand other Difafters, whereby he could have carried them off by Moles, yea fwept them all clear away. Befides, he had the whole Artillery of the Sky in his power, and might prefently have Thunder ftruck them all, or deftroyed them by Fire from Heaven. But none of all the e were ufed, though 'ris moft apparent that any of them would have been as fatal and pernicious to Man as the Deluge was, for the Defign lay a great deal deeper, and the fe would have fallen fhort of it: thefe 
would never have reach'd the Earth, nor affected that in the leaft : they could never have touch'd the Head, or ftop'd the fource of thefe unhappy mif demeanours, for which the Punifhment was fent. That was what nothing but a Deluge could reach; and as long as the Caufe remained : as long as the old Temptation was ftill behind, every Age would have lain under frefh Inducements to the fame Crimes: and there would have been a new neceffity to punifh and reclaim the World: to depopulate the Earth, and reduce it again to a vaft Solitude, as conftantly as there fucceeded a new Age and Race of Men. For the terror of the Calamity would not have extended it felf much farther than the Men which fuffered under the weight of it: and a few Years would have worn out, in great meafure, the Impreffions it made. This we fee even from the Example of the Deluge it felf. As formidable as this was to thofe who lived at, or near, the time of it: who faw the prodigious Devaftations it made: the horrible Methods by which 'cwas brought about : and the Reafon why 'twas inflicted; and to their Po' Aterity 


\section{Part II.}

fterity, for a few Generations; yet the Fright was not lafting: 'twas not long e're the Sting of it was worn out. And though the Elder Ages knew full well that there had been fuch a Deluge: and had fome Tradition of the cruel Defolation it made ; yet by degrees the Particulars of it were drop'd, and the moft frightful Paffages bore the leaft thare in the Relation; being probably fo frrange/as to be hardly credible; and carrying rather an appearance of Figment and Invention, in thofe that handed down the memory of it, than of Truth and Reality. So that upon the whole 'tis very plain that the Deluge was not fent only as an Executioner to Mankind: but that its prime Errand was to reform and new-mold the Earth.

That therefore as much Harfhnefs and Cruelty as this great Deftruction of Mankind feemingly carries along with it: as wild and extravagant a thing as that Diffolution of the primitive Earth appeared at firft fight, yet all the Severity lay in the Punifhment of that Generation, (which yet was no more than what was highly juft, yea and neceffary too:) and the whole 
of the Tragedy terminated there. For the Defruction of the Barth was not only an ACt of the profoundeft Wifdom and Forecaft, but the moft monumental proof that could ever poffibly have been, of Goodnefs, Compaffion, and Tendernefs, in the Author of our Being; and this fo liberal too and extenfive, as to reach all the fucceeding Ages of Mankind: all the PoAterity of Noah : all that fhould dwell upon the thus renewed Earth to the End of the World; by this means removing the old Charm: the Bait that had fo long bewildred and deluded unhappy Man : fetting him once more upon his Legs : reducing him from the moft abject and ftupid Ferity, to his Senfes, and to fober Reafon: from the moft deplorable Mifery and Slavery, to a Capacity of being happy.

That notwithftanding that this Remedy ftruck as deep at the Intellectuals, as at the Morals of Mankind : that Ignorance and Rudenefs would be as neceffary a Confequence of it, as Reformation of Life: and that this fo general Employ and Expence of their rime would as affuredly curtail and retrench the ordinary means of Knowledge 


\section{Pare II. of the Eartb.}

ledge and Erudition*, as 'twould fhor- * Confor. ten the Opportunities of Vice: And fo p. 55. \& accordingly it fell out; An univerfal Rufticity prefently took place, fpread on all hands, and ftop'd not till it had over-run the whole ftock of Mankind. Thofe firft Ages of the new World were fimple, and illiterate to Admiration; and 'twas a long time e're the Cloud was withdrawn: e're the leaft fpark of Learning (I had almoft faid of Humanity) broke forth, or any Man betook himfelf to the promotion of Science. Nay the Effects of it are vifible to this hour : a general Darknefs yet prevails, and hangs over whole Nations, yea the far greater part of the World is ftill barbarous and favage. I fay, tho 'twas moft evident that this Remedy muft needs have tbis Confequence alfo as well as the other, yet it was not fufpended or chang'd upon that account; An egregious and pregnant inftance how far Vertue furpafies Ingenuity : how much an honeft Simplicity, Probity of Mind, Integrity and Incorruptnefs of Manners, is preferable to fine Parts, profound Knowledge, and fubtile Speculations. I would not have this interpreted an invective 
againft Humane Learning, or a decrying any commendable Accomplifhments either of Body or Mind, (that is what no Man will, I hope, fufpect me of ) but only an intimation that thefe are not of any folid ufe, or real advantage, unlers when aiding and ferviceable to the other.

Nor does this grand Cataftrophe only prefent us with Demonftrations of the Goodnefs, but alfo of theWifdom and Contrivance of its Author. There runs a long train of Providence thro the whole: and Shines brightly forth of all the various Accidents of it. The Confolidation of the Marble, and of the Stone, immediately after their Settlement to the bottom: the difruption of the Strata afterwards : their Diflocation, the Elevation of fome, and Depreflion of others of them, did not fall out at random, or by chance, but were managed and directed by a more fteady and difcerning Principle ; for proof whereof, this is indeed the proper place: but, in regard that there are fome things advanced in the fucceeding, or third, Part of this Difcourfe, which give fome farther light to this matter, I thall beg leave to break off here, and 


\section{Part II. of the Earth.}

to deferr it a while, untill I have firft propofed them.

Thus have I drawn up a brief Scheme of what befell the Earth at the Deluge: and of the Change that it then underwent. I have, by comparing its Antediluvian * with its prefent ftate, found where * Conf. chiefly the Difference lay; viz. in de-Part 6. gree of Fertility. I have endeavour'd alfo to difcover the Reafon why this Change was made in it. For fince that the Procefs of it was fo folemn and extraordinary: that there were fo many, and thofe fo ftrange things done: that the firft Earth was perfectly unmade again, taken all to pieces, and framed a-new; and indeed, the very fame Method that was ufed in the original Formation of it, ufed likewife in this Renovation; our Eartb ftanding the firft ftep after its Diffolution, in the fame pofture that the Primitive Earth did the firft ftep after its Rije out of Nothing; which the Reader will eafily find by conferring the fifth Propofition of this Part with Gen. i.v. 2. and 9: fince likewife there was fo mighty an Hand + concerned, and which does + conf. not act without great and weighty Part 3 . Reafons, there could be no doubt but $\operatorname{seft} .2$. 
that there was fome real and very neceffary Caufe for the making that Alteration. Nor was fuch a Caufe very hard to be found out. The firft Earth was fuited to the firft ftate of Mankind ; who were the Inhabitants of it, and for whole ufe 'twas made. But when Humane Nature had, by the Fall, fuffer'd fo great a Change, 'twas but neceffary that the Earth fhould undergo a Change too, the better to accommodate it to the Condition that Mankind was then in: and fuch a Change the Deluge brought to pafs.

But lealt that the Brtvity which I have above ufed, and which indeed I am tied up to, in my Reprefentation of this matter, should render it liable to Mifconftruction: or that any one fhould fufpect, that what I have delivered concerning the Fertility of that Earth, does not well fquare with the Mofaick Defcription of it, I muft beg leave to make a Digreffion here, that I may explain my felf a little more upon that Head. And that the Reader may himfelf be Judge in the Cafe, I fhall fairly lay down Mofes's fenfe of it in his own words. 


\section{Part II. of the Earth.}

Ver. 17. And unto Ldam be faid, be Gen. iii.

caufe thou baft bearkned wnto the Voice of thy wife, and hast eaten of the Tree of which I commanded thee, Caying, thow balt not eat of it: Curfed is the ground for thy fake; in forrow Bbals thou eat of it all the days of thy life.

Ver. I8. Thorns alfo and Thifles fall it bring forth to thee: and thou foult eat the berb of the field.

Ver. g. In the fweat of thy face foalt thou eat bread, till thou return unto the ground; for out of it waft thow taken: for duft thow art, and unto duft Salt thou return.

Ver. 23. Therefore the Lord God fent him forth from the Garden of Eden, to till the ground from whence be was taken. Ver. 2. Cain was a tiller of the ground. Gen. iv.

All which may be well reduced to two plain and fhort Propofitions,

1. That Adam's Revolt drew down a Curfe upon the Earth.

2. That there was fome fort of Agriculture ufed before the Deluge.

As to the former, the Curfe upon the Earth, I hall not in the leaft go about to extenuate the Latitude of it: or to ftint it only to the Production of Weeds, of Thorns, Thifles, and other

$$
\mathrm{H}_{2} \text { the }
$$


the lefs ufeful kinds of Plants : but Thall give it its full fcope, and grant that no lefs than an univerfal Reftraint and Diminution of the primitive Fruitfulnefs of the Earth was intended by it; this indeed feeming to be the plain and genuine meaning of the words. But the Queftion is, whether this Curre was prefently inflicted or not: whether it was fucceeded with an univerfal Sterility, and the Earth's native and original Exuberance all ftraitways check d, and turn'd to as general a Defolation and Barrennefs. And here I entreat it may be taken notice, that $t$ is was but one, and that much the leffer, part of the Sentence paft upon Adam. The other was Death *; which, "tis moft certain, * Conf. was not immediately inflicted. And Rom. v. yet this was pronounc'd at the fame I Cor. xv. time and with the fame breath, that 21, 22. the other was: Unto duft falt thou return. Nay and much more emphatically a little before $\|$, In the day that i Gen.iir 7. thou eateft thereof thow fbalt furely dye. This was exceedingly peremptory: and the very day fix'd likewife. Notwithitanding, through the Clemency and Goodnefs of God, Execution was delayed for a long time; Adam being reprieved 


\section{Part II. of the Earth.}

reprieved for eight or nine hundred years $\uparrow$. The Dominion of Deash over him commenc'd indeed not only + Gen.v. 5 . the fame day that Sentence was paft, but the very minute that he tafted the forbidden Fruit : and Mortality went hand in hand with the Tranfgreffion: but 'twas a long time before it had raifed any Trophies, or made a final and abfolute Conqueft.

Why therefore may we not as well fuppofe the other part of the Sentence, the Sterilizing the Earth, was alfo fufpended for fome time, and deferr'd till the Deluge happened, and became the Executioner of it? 'Tis certainly very hard to imagine that God fhould deftroy the Work of his hands almolt as foon as he had finifh'd it : that all things thould be unhinged again by fuch time as they were well ranged and put in order: and that the Fragrancy and lovely Verdure which then appeared every where, and which had but juft thewed it felf, thould be nip'd in the bud, and blafted all of a fudden. To be fhort, 'tis, I think, moft apparent, that as on the other part Mortality did prefently enter and take place, but got not full poffeffion of many $\mathrm{H}_{3}$ Ages 
Ages after: fo here, Thorns, Thiftles, and other the like Confequences of this Curfe, immediately fprung out of the Ground, and manifefted themfelves on every fide, but it had not its full effect, nor was the Earth impoverifh'd, or its Fertility, fenfibly curb'd, till the Deluge. And for proof of this I appeal to the Remains of that Earth: the Animal and Vegetable Productions of it ftill preferved; the vaft and incredible Numbers whereof notorioufly teftifie the extreme Luxuriance and Focundity of it ; and I need but produce the $\int e$ as Evidences that at the time that the Deluge came, the Earth was fo loaded with Herbage, and throng'd with Animals, that fuch an Expedient was even wanting to eafe it of the burden, and to make room for a fuccefion of its ProduCtions. For this alfo I appeal to Mo/es himfelf, who openlyacknowledgeth that this Curfe did not take place effectually till the Deluge. For be tells us, that, after the Deluge was cver, and Noab and his Family come forth of the Ark, He builded an Altar wato the Lord, and offered burnt-offerings on the Aliar: and the lord /melled a fmeet favour, asd the Lord faid in bis beurt, I will not again 
Part II. of the Earth. $\quad 103$.

Curfe the Ground any more, neither will I again Smite any more every thing living as I bave done* . Wherein he * Gen. viii. plainly refers to the Curfe denounc'd ${ }^{20,21 .}$ above, at the Apoftacy of Adam: implying that it was not fulfilled till the Deluge. And a little after he as plainly intimates, that the fulfilling of it lay in the Deftruction of the Earth then wrought. For, fpeaking again of the fame thing, inftead of the Expreffion [Curge the Ground] here ufed, he makes ufe of [Deftroy the Earth.] The whole Paffage runs thus; And I woill eftablifb my Covenant with you, neither Shall all fle $\mathrm{h}$ be cut off any more by the wa. ters of a flood: neither fball there any more be a Flood to deftroy the Farth*. "Gcm. ix.

Nor is it indeed in any wife ftrange that this Curfe had not it's Effect fooner: efpecially fince 'twas not limited to any time. There are fo many Prefidents on Record in Holy Writ of this way of proceeding, that no one can be well ignorant of them; fo that I hall not need to charge this place with more than one, and that thall be the Cafe of Ham, for which we are likewife beholden to the fame Author,

$$
\mathrm{H}_{4} \text { Moges. }
$$


Mofes. This Perfon, by his indifcreet and unnatural Irrifion and expofing of his Father, incurrs his Indignation, and Curfe. But, which is very remarkable, Noab does not lay the Curfe upon Ham, who was actually guilty of the Crime, whether out of greater Tendernefs, he being of the two nearer allied unto him, or for what other reafon I thall not here enquire, but transferrs it to Canaan: Curfed be $C_{a}$. $\|$ Gen ix. naan, a Servant of Servants Sall be be $25,26,27$. to bis Brethren: to Shem and to Faphet. Nay, which is ftill more, this was never inflicted upon $C_{\text {anaan }}$ in perfon, but upon his Polterity; and that not till many Generations afterwards', at fuch time as the Ifraelites returning out of Egypt, poffert themfelves of the Counrry of the Cinaanites, and made them their Servants. The Story is fo well known, that I fhall not need to point it out to the Reader, who may perufe it at his leifure. 'Twas well onwards of a thoufand Years before ever this Curfe began to take effect: before the Canaanites were brought under Servitude by the Ifraelites, who were defcended from Shem: and a great many more before ' $t w$ as finally accomplinh$e d$, and they fubjected unto the Pofterity 


\section{Part II. of the Earth.}

rity of $\mathcal{F}$ aphet. To conclude, 'twas really a longer time before this, than it was before the otber, the Curfe upon the Earth, was fully brought about.

To proceed therefore to the other Point, the Tillage of the Earth before the Deluge. That there was Tillage beftowed upon it Mofes does indeed intimate in general and at large: but whether it was beftowed on all, or only upon fome parts of that Earth: as alfo what fort of Tillage that was, and what Labour it coft, is not expreft; fo that for all this we are at liberty, and may ufe our Difcretion. For the prefent I muft pafs by the Enquiry: but in due place I hope to give fome Satisfaction in it, and to thew that their Agriculture was nothing near fo laborious, and troublefome, nor did it take up fo much time as ours doth. That's a Confequence of the Proof of the greater Fertility of that Earth; it being plain that the more it exerted that Fertility, the lefs need there was of Manure, of Culture, or Humane Induftry to excite and promote it. Nor can any Man reafonably fufpect, becaufe of this mention of Tillage, that the Curfe upon the Ground was come 
on, or that the primitive Exuberance of the Earth was leffened and abridged, before the Deluge; for Mofes makes mention of Tillage before ever Adam t Gen.ii. s. was created: There was not, fays he $t$, a man to till the ground: and confequently, there would have been requifite fuch a Tillage as this which he fpeaks of in thefe three Chapters, tho" the Curfe had never been denounc'd, or Man had not fallen. But 'tis highly probable that upon Adam's Difobedience, Almighty God chafed him out of Paradife, the faireft and moft delicious part of that Earth, into fome other the moft barren and unpleafant of all the whole Globe; the more effectually to fignifie his Difpleafure, and to convince that unhappy Man how great a Misfortune and Forfeiture he had incurred by his late Offence. And here, above all other Parts of the Earth, there would be Work and Employ for him, and for his Son Cain.

And thus much may ferve for the prefent, to hew that my Account of the Antediluvian Earth is fo far from interfereing with that which Mofes hath given us, that it holds forth a natural and unforc'd Interpretation of his 
Senfe on this Subject. There are a few other Paffages in the fame Author which may require fome Explication: but they are none of them fuch that a Reader of moderate Underftanding may not eafily clear them, without my Affiftance, fo that I thall not crowd this Piece with them ; for I fear' $t w$ ill be thought that I have already taken too great a liberty. The Compafs that I am confined unto, by the Rules of this kind of Writing, is fo narrow, that I am forced to pafs over many things in filence, and can but juft touch upon others. To lay down every thing at length, and in its full light, fo as to obviate all Exceptions, and remove every Difficulty, would carry me out too far beyond the Meafures allowed to a Tract of this Nature. That's the Bufinefs of the Larger Work, of which this is only the Module or Platform. In that Work I hope to make amends for thefe Omiffions, and particularly fhall confider

What was the immediate Inftrument or Means whereby the Stone, and other folid Matter of the Antediluvian Earth was diffolved, and reduced to the Condition mentioned Confect. 2. of this Part. 
Why the Shells, Teeth, Bones, and other parts of Animal Bodies : as alfo the Trunks, Roots, and other parts of Vegetables, were not diffolved, as well as the Stone, and other Mineral Solids of that Earth. Of this I thall affign a plain and Phyfical Reafon, taken meerly from the Caufe of the Solidity of thefe Mineral Bodies; which I thew to be quite different from that, whereunto Vegetables and Animals owe the Cohrfion of their parts : and that this was fufpended, and ceafed, at the time that the Water of the Deluge came forth; which the other (I mean the Caufe of the Cohxfion of the Parts of Animals and Vegetables) did not; with the reafon of this.

What was the Reafon that (in cafe the Terreftrial Globe was entirely diffolved, and there be now, and was then, a Space or Cavity, in the Central parts of it, fo large as to give reception to that mighty Mafs of Water which covered the Earth at the De* vid. luge *) the Terreftrial Matter which Part 3. firit fubfided, (as in Confect. 3. Supra) sect. I. I. did not fill the faid Cavity, and defcend
consect. I. dit and quite down to the Center, but ftop'd at $S_{i c t} c_{2 .}$.
$C_{02 n} f_{2,3}$ that diftance from it, forming an arch- 


\section{Part II. of the Earth.}

ed Expansum, or rather a Sphere around it ; which is now the loweft Stratum, and Boundary of that vaft Conceptacle of Water. As alfo how this Water was raifed at the Deluge: by what Iffues or Outlets it came forth : what fucceeded into the room of it, whillt abfent: and which way it returned back again.

By what means the Strata of Stone, and Marble, acquired fuch a Solidity, as foon as the Matter, whereof they confift, had fubfided, and was well fettled to the bottom, as in Confect. 4. of this Part.

What was the immediate Agent which effected that Difruption of the Strata, and their Dillocation afterwards; whereof in Confect.6. of this Part.

And becaufe there have been fome Conjectures formerly ftarted by Learned Men about the Formation of SandStone, the Origin of Mountains, and of Iflands, that are repugnant to what I have here advanc'd upon thofe Sub. jects, I am obliged to look a little into the Reafons of them; and, that they may not remain as Obftacles to thofe who are lefs skilfull in thefe things, I 
fhall weigh their Arguments, deted the Invalidity of them, and prove, againft them, -

That the Sand-Stone now in being is not as old as the Earth it felf : nor hath it been confolidated ever fince the Creation of the World, as fome Authors have believed.

That Sand-Stone does not now grow by Fuxtapofition, as they fpeak; that is by continual Addition of new Matter; in like manner as the Bodies of Animals and of Vegetables grow, and are aug. mented ; as others were of Opinion.

That Sand-Stone does not ftill confolidate : i.e. that Matter which was, a few Years ago, lax, incoherent, and in form of Earth, or of Sand, does not become daily more hard and confiftent, and by little and little acquire a perfect Solidity, and fo turn to Stone; as others have afferted.

That the Mountains of our Earth have not had being ever fince the Creation: and ftood as long as the Earth it felf; as fome Writers have thought.

That the faid Mountains were not raifed fucceffively, and ar feveral times; being flung up or elevated by Earthquakes, fome at one time, and fome at another, 


\section{TPart II. of the Earth.}

another, as thofe Earthquakes happened. That thefe are fo far from railing Mountains, that they overturn and fling down, fome of thofe which were before ftanding; and undermine others, finking them into the Abyfs underneath t. $^{2} \quad$ That of all the Mountains + Confer. of the whole Globe, which are very Part 3. numerous, and many of them extreme-conf. 12. $1 y$ large, and confequently cannot be fuppoled to have been all thus raifed without the Notice of Mankind, yet there is not any authentick Inftance, in alt Hiftory, of fo much as one fingle Mountain that was heaved up by an Earthquake. That the new Mountain in the Lucrine Lake, not far from Pozzuolo in Italy, called Monte di Cizzere, which is alledged by the Fautors of this Opinio, as an inftance in behalf of it ${ }_{2}$ was not raifed thus; the Relators of that Accident, as well thofe who were then living, as they who wrote fince, unanimoully agreeing that this Tusulus, or Hill, is no other than an huge heap of Stones, Cinders, Earth, and Ahes, which were fpued up out of the bowels of the Earth, by the Eruption of a Volcano, which happened there, in the Year 1538. And 
though this Eruption was preceded by feveral Earthquakes (the Country all round having been frequently thaken for almolt the fpace of two years before) as thofe of Etna, Vefuvius, and Hecla ufually are, yet this Hill was not elevated or heaved up by any of thofe Earthquakes, but the Matter, whereof 'tis compiled, difcharged out of the $V o l c a n o$, as aforefaid; in like manner as Atna, Vefuvius, and the reft, fling forth Stones, Cinders, or. upon any extraordinary Eruption of them.

That there have not been any I/lands of note, or confiderable extent, torn and caft off from the Continent by Earthquakes, or fevered from it by the boifterous Allifion of the Sea. That Sicily, Cyprus, the Negropont, and many more, which have been fuppofed by fome to be only difmembered parcels of the Main-land, and anciently parted from it by one or other of thele means, yet really never were fo; but have been Iflands ever fince the time of the Noetick Deluge.

Unto this Second Part I fhall annex,

A Difcourfe concerning the Trees, which are commonly called Subterranean Trees, or Fufal Wood, and which 
are found in great plenty buried 113 amongft other Vegetable Bodies in Mófes *, Fens, or Bogs, not only in "Mofs is feveral Parts of England, but likewife the Name in many Foreign Countries; whberein $I$ over all the thall hlew, from Obfervations made North of upon the Places where thefe Trees are infingand $^{\text {Englan }}$ digg d up: upon the Trees themfelves: of rato their Pofition in the Earth, and other Circumftances, that they were lodged thus by the Delinge, and have lain bere ever fince. That there are found great numbers of thefe Trees, and many of them very large, fo buried in feveral Iflands where no Trees at all do, or will, now grow the Winds being fo fierce, and the Weather fo fevere, as not to fuffer any thing to prôper or thrive beyond the height of a Shrub, in any of all thofe Inands, unlers it be protecled by Walls, as in Gardens, or other like Coverture. That the faid Trees are in fome places found enclofed in the Stone of Quarries and of Rocks : buried amongft Marle, and other kinds of Earth, as well as in this Peat or Mofs:Earth. That they were origithally lodged indifferently amongft all forts of Earth, or otherr Matter, which lay: gear the Surface of the Earth $\uparrow$ : and $\operatorname{conf}_{-3}$. 
that they are at this day found very feldom unlels in this Peat-Earth, is meerly accidental, this Earth being of a bituminous and mild Nature; fo that the Trees lay all this while, as it were, embalmed in it, and were by that means preferved down to our times; whilft thofe which chanced to be logged in other Earth, that was mare lax and pervious, decayed in tract of cime, and rotted at length, and therefore do not now appear at all, when we dig and fearch into thofe Earths; or if any thing of them do appear tis only the Ruins, or fome light Remains of them; there being very rarely found any Trunks of Trees, in thefe laxer Easths, that are intire, or tolerably firm and found. To conclude, from feveral of the aforefaid Circumftances $I_{\text {thall }}$ evince that thefe Trees could never poffibly have been repofed thus by any other means than the Deluge neither by Men : nor by Inundations nor by

"Confer. Deterations* : nor by yiolent and im. Part 5. which are the feveral ways whereby Learned Men have thonght they were thus buried. 
Part III. of the Earth.

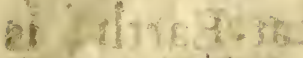

P A R T III.

Concerning the Fluids of the Glabe.

\section{S E C T. I.}

Of the great $A b y \int s$. Of the Ocean? Concerning the Origine of Springs, and Rivers. Of Vapours, and of Rain.

HAving thus done with the more 1 bulky and Corpulent Parts of the Globe, the next place in courfe is due unto Metalls and Minerals, which are the only remaining part of the Terreftrial Matter of it not yet treated of. And accordingly I fhould now pafs on to thefe; but the prefent Oeconamy and Difpofal of fome of them being wholly owing to the Motion and Paffage of Water in the interiour parts of the Earth, I have for that reafon cho- 
fen rather, that I may be as brief as polible, and avoid all needlefs Repeticions, to wave them for a while, till I have firtt offered what I have to fay sbout that.

The Weter therefore of the Globe, as well that refident in it, as that which floats upon it, is the Subject which I purpole here to profecute. In order whereunto, I Thall fub-divide this third Part into two Sections; the former whercof will comprehend what relates to the prefent and natural State of the Fluids in and upon the Earth : the other, what concerns that extraordinary Change of this State which happened at the Deluge, and how that Change was wrought.

At the Head of the firt of thefe SeCtions I prefix a new fet of Ob/ervations touching the Fluids of the Terraqueans Globe: the Sea, Rivers, and Springs: the Water of Mines, of Cole-pits: of Caves, Grotts, and the like Recelfes: as alfo concerning Vapours, Rain, Hail, and Snow.

And becanfe this is a Subject of that vaft Latiude that the Strength of one fingle Man will farcely be reckoned Cufficient effectually to cultivate and

carry. 


\section{Part III. of the Earth.}

carry it on, I have taken in the joint Affiftance of other Hands, and fuperadded, to my own, all fuch Relations as I could procure from Perfons whofe Judgment and Fidelity might fafely be relyed upon, about the Sea, Lakes, Rivers, Springs, and Rain, not only of this Ifland, but many other Parts of the World befides. Nor do I neglect thofe which are already extant in the $P$ Publifbed Difcourfes of diligent and inquifitive Men.

From all which Obfervations, joyned with thofe made by my felf, I prove,

That there is a mighty Collection of Water inclofed in the Bowels of the Earth, conftituting an buge $O r b$ in the interiour or central Parts of it ; upon the Surface of which Orb of Water the terreftrial Strata are expanded. That this is the fame which Mofes calls the Great Detp, or $A b y \beta$ : the ancient Gentile Writers, Erebus, and Tartarus.

That the Water of this Orb comsmunicates with that of the Ocean, by means of certain Hiatus's or Chafmes pafling betwixt it and the bottom of the Ocean. That they have the fame common Center, around which the Water of I 3 both 
both of them is compiled and arranged; but in fuch manner, that the ordinary Surface of this Orb is not level with that of the Ocean, nor at fo great a diftance from the Center as that is, it. being for the moft part reftrained and depreffed by the Strata of Earth lying upon it ; but wherever thofe Strata are broken, or fo lax and porofe that Water can pervade them, there the Water of the faid Orb does afcend: fills up all the Fiffures whereinto it can get Admiffion or Entrance : and faturates all the Interftices and Pores of the Earth, Stone, or other Matter, all round the Globe, quite up to the level of the Surface of the Ocean.

3. That there is a perpetual and inceffant Circulation of Water in the Atmophere : it arifing from the Globe in form of $V$ apour, and falling down again in Rain, Dew; Hail, and Snow. That the quantity of Water thus rifing and falling is equal; as much returning back in Rain, \&6. to the whole terraqueous Globe, as was exhaled from it in Vapours: and reciprocally as much mounting up again in Vapour as was difcharged down in Rain. That tho? the quantity of Water thus rifing and 


\section{Part III. of the Earth.}

falling be nearly certain and conftant as to the whole, yet it variès in the feveral Parts of the Globe ; by reafon that the Vapours float in the Atmorphere, failing in Clouds from place to place, and are not reftored down again in a Perpenidicular upon the fame precife Tract of Land, or Sea, or both together, from which Originally they arofe, but any other indifferently; fo that fome Regions receive back more in Rain than they fend up in Vapour: as, on the contrary, others fend up more in Vapour than they receive in Rain: nay, the very fame Region at one Seafon fends up more in Vapours than it receives in Rain, and at another receives more in Rain than it fends up in Vapour; but the Exceifes of one Region and Seafon compenfating the Defects of the others, the quantity rifing and falling upon the whole Globe is equal, however different it may be in the feveral $P$ arts of it.

That the Rain which falls upon the Surface of the Earth partly runs off into Rivers, and thence into the Sea: and partly finks down into the Earth, inft nuating it felf into the Interftices of the Sand, Gravel, or other Matter of the

$$
\text { I } 4 \text { exte- }
$$


exteriour or uppermoft Strata; whence fome of it paffes on into Wells, and into Grotts, and ftagnates there, till 'tis by degrees again exhaled: fome of it glides into the perpendicular Intervalls of the folid Strata; where, if there be no Outlet or Pafiage to the Surface, it ftagnates, as the other : but if there be fuch Outlets, 'tis by them refunded forth together with the ordinary $\mathrm{Wa}$ wer of Springs and Rivers : and the rest, which, by reafon of the compactnefs of the terreftrial Matter underneath, cannot make its way to Wells, the perpendicular Fiffures, or the like Exits, only faturates the uppermoft Strata: and in time remounts up again in Vapour into the Atmolphere.

5: That although Rains do thus fall into, and augment Springs and Rivers, yet neither the one nor the other do derive the Water, which they ordinaririly refund, from Rains; notwithftanding what very many Learned Men have believed.

6. That Springs and Rivers do not proceed from $V$ apours raifed out of the Sea by the Sun, borne thence by Winds unto Mountains, and there condenfed, as a modern ingenious Writer is of Opinion.

That 


\section{Part IH. of the Earth.}

\section{That the abovementioned great fub- 7 .}

terranean Magazine the $A b y \int s$, with its Partner the Ocean, is the Standing Fund and Promptuary which fupplies Water to the Surface of the Earth: as well Springs and Rivers, as Vapours and Rain.

That there is a nearly uniform and 8 . conftant Fire or Hieat $\|$ diffeminated throughout the Body of the Earth, and efpecially the interiour Parts of it; the bottoms of the deeper Mines being very fultry, and the Stone and Ores there very fenfibly

|| Heat wad Fire differ but in degree : and Heat is Fire only ins leffer quantity. Fire I jall Shew to be a Fluid confffing of Parts extremely fmall and light, and confequently very fubtile, active, and fusceptive of Motion. An Aggregate of thefe Parts in fucts number as to be vifible to the Eye, is what we call Flame and Fire : a lefier, thinner, and more dispers'd Gollection, Hear and bot even in Winter, and the colder Seafons. That 'tis this Heat which evaporates and eleyates the Water of the Aby Is, buoying it up indifferently on every fide, and towards all parts of the Surface of the Globe: pervading not only the Fiffures and Intervals of the Strata, but the very Bodies of the Strata themfelves, permeating the Interftices of the Sand, Earth, or other Matter, whereof they confift: yea even the moft firm and denfe 
denfe Marble and Sand-ftone; for thefe give Admiffion to it, though in leffer quantity, and are always found farurated with it; which is the reafon that they are.fofter, and cut much möre eafily, when firft taken out of their Beds and Quarries, than afterwards, when they have lain fome time expofed to the Air, and that Humidity is evaporated.

That this Vapour proceeds up directly towards the Surface of the Globe on all fides, and, as near as poffible, in right Lines, unlefs impeded and diverted by the Interpofition of Strata of Marble, the denfer forts of Stone, or other like Matter, which is fo clofe and compact that it can admit it only in fmaller quantity, and this very flowly and leifurely too.

That when it is thus intercepted in its palfage, the $V$ apour, which cannot penetrate the Stratum diametrically, forme of it glides along the lower Surface of it, permeating the horizontal Interval which is betwixt the faid denfe Stratum and that which lies underneath it: the reft paffing the Interftices of the Mafs of the fubjacent Strata, whether they be of laxer Stone, of Sand, of

Marle, 
Marle, or the like, with a Direetion parallel to the Site of thofe Strata, till it arrives at their perpendicular Intervalls.

That the Water being thus approach'd to thefe Intervalls, in cafe the Strata, whereby the afcending Vapour was collected and condenfed into $\mathrm{Wa}$ ter (as we ufually fpeak) in like manner as by an Alembick, happen to be raifed above the level of the Earth's ordinary Surface, as thofe Strata are whereof Mountains confift, then the Water, being likewife got above the faid level, flows forth of thofe Intervalls or Apertures, and, if there be no Obftacle withiout, forms Brooks and Riz vers : but where the Strata, which fo. condenfe it, are not higher than the mean Surface of the Earth, it ftagnates at thie Apertures, and only forms Standing-Springs.

That though the Supply from this great Receptacle below be continual, and nearly the fame at all Seafons, and alike to all parts of the Globe, yet when it arrives at or near the Surface of the Earth, where the Heat (the Agent which evaporates and bears it up) is not So conftant and uniform as is that re- 
fident within the Globe, but is fubject to Vicifitudes and Aiterations, being at certain Seafons greater than at others: being alfo greater in fome Climates and Parts of the Earth than in others : it thence happens that the quantity of $W$ ater at the Surface of the Earth, though fent up from the Aby is with an almoft conftant Equality, is warious and uncertain, as is the Heat there; at fome Seafons, and in fome Countries, the Surface abounding, and being even drowned with the plenty of it, the Springs full, and the Rivers bigh: at otber Seafons, and in other Countries both Springs and Rivers exceeding low, yea fometimes totally failing.

That whon the Heat in the exteriour $P$ arts of the Earth, and in the ambient Air, is as intenfe as that in the interiour Parts of it, all that Water which paffes the Strata directly, mounting up in feparate Parcels, or in form of $V_{a-}$ pour, does not ftop at the Surface, becaufe the Heat there is equal both in quanticy and power to that underneath, which brought it out of the Abyfs. This Heat therefore takes it here, and bears it up, part of it immediately out 
Part III. of the Earth.

at the Surface of the Earth: the reft, through the Tubes and Veffels of the Vegetables which grow thereon,Herbs, Shrubs, and Trees, and along witk it a fort of vegetative terreftrial Matter, which it detaches from oulf the uppermoft Stratum wherein thefe are planted; this it depofes in them, for their Nutriment, as it pafles through. them +; and iffuing out at the tops +ridicons. and extremities of them, it marches tos infress.

ftill on, and is elevased up into the Atmo ophere to fuch height that, the Heas being there lefs, it becomes condenfed, unites and combines into fmall Maffes or Drops, and at length falls down again in Rain, Dew, Hail, or Szzow. And for the other part of the Water, which was condenfed at the Surface of the Earth, and fent forth collectively into Stindirg-Springs and Rivexs, this alio fuitains a Diminution from the Heat above, being evaporased, more or lefs, in proportion to the greater or leffer Intenfenefs of the Heat, and the greater or lefier Exsent of the Surface of the Water fo fent forth.

That as thefe Evaporations are at fome times greater, according to the greater beat of the San, fo wherever they

alighe 
alight again in Rain, 'tis as much fuperiour in quantity to the Rain of colder Seafons, as the Suns poper is then fupe: riour to its power in thofe Seafons. This is apparent even in thefe Nortbern Climes, where the Suns power is never very great, our Rains in Fune, fuly, and Auguft, being much greater than thofe of the colder Months: the Drops larger, and confequently heavier: falling thicker, fafter, and with greater force: Atriking the ground, at their fall, with violence, and making a mighty noife : beating down the fruit from the Trees, proftrating and laying Corn growing in the Fields: and fometimes fo filling the Rivers as to make them out-fwell their Banks, and lay the neighbouring Grounds under Water. But much more apparent is it in the more Soutbern Regions : in Abafinia, Nigritia, Guinea : in the Eaft. Indies in Brafil, Paraguay, and other Countries of South America, to inftance in no more. In thefe the Sun thews a much greater force: and their Rains (which are periodical, happening atways much about the fame time, and lafting feveral Months) fall in fuch quantities as to be more like Rivers defcend 


\section{Part III of the Eartb.}

defcending, than Showers; and by these are caufed thofe mighty periodical Inundations of the Nile, the Niger, the Rio de Volta : the Ganges: the Rio de las Amazonas, the Rio de la Plata, and other Rivers of thofe Countries; to which Inundations Egyps, through which the Nile flows, the Indies, and the reft owe their extraordinary Fertility, and thofe mighty Crops they produce after thefe Waters are withdrawn from off their Fields; Rain waster a as we have already noted *, ${ }^{\circ}$ ogs. 47。 carrying along with it a fort of terrefrrial Matter that fertilizes the Land, as being proper for the Formation of Vegucables.

That when the Heat in the exteriour Parts of the Earth, and in the ambient Air, is les than that in the interiour, the Evaporations are likewife lefs, and the Springs and Rivers thereupon do not only ceafe to be diminithed t, proportionably to the Relaxation + conf.

of the Heat, but are much augmented; pags. iss.

a great part of the Water, which af. cends to the Surface of the Earth in $V_{A}$ pour, fopping there, for want of Heat to mount if thence up into the Atmofphere, and faturating the fuperficial

or 
or uppermoft Strata with Water, which by degrees drains down into Wells, Springs, and Rivers, and fo makes an Addition unto them. And this is the reafon that thefe abound with Water in the colder Seafon fo much more than they do in the botter.

9. That the Water, which is thus difpens'd to the Earth and Atmoplpere by the Great $A b y$ s, being carried down by Rains and by Rivers into the Oceart, which, as we have faid, communicates? and ftands at an Equilibrium with that fubterranean Confervatory, is by that means reftored back to the Abyfs; whence it returns again, in a continual Circulation, to the Surface of the Earth, in Vapours, and Springs.

10. That the final cinje of this Diftriburtion of Water, in fuch quantity, to all parts of the Earth indifferently in Springs, Rivers, and Rain : and of this perpetual Circulation and Motion of it, is the Propagation of Bodies, Ani mals, Vegetables, and Minerals, in a continued Succeffion. That for Animals, they either feed upon Vegetables immediately: or, which comes to the fame at laft, upon other Animals which ave fed upon them; fo that Vegetas 
Part III. of the Earth.

bles are the firft and main Fund, and fit Matter being fupplied unto the e, Provifion is thereby made for the Nourifbment of Animals; thefe Vegetables being no other than fo many Machines ferving to derive that Matter from the Earth, to digeft and prepare it, for their food, leifurely and by little and little, as they can admit and difpofe of it, and as it is brought to them by the Miniftration of this Fluid. That Vegetables being naturally fix'd and tyed always to the fame place, and fo nor able (as Animals are ) to thift, and feek out after Matter proper for their Increment, 'twas indifpenfably neceffary that it fhould be brought to them : and that there thould be fome Agent, thus ready and at hand in all places, to do them that Office, and fo carry on this great and important Work. For this Matter being impotent, fluggifh, and inactive, hath no more power to ftir, or move it felf to the fe Bodies, than they themfelves have to move unto it ; and therefore it mult have lain eternally confined to its Beds of Earth, and then none of thefe Bodies could ever have been formed, were there not this, or the like, Agent to educe it thence, 
and bear it unto them. Nor does the Water, thus hurried about from place to place, ferve only to carry the Matter unto thefe Bodies, but the parts of it being very voluble and lubricous, as well as fine and fmall, it eafily infinuates it felf into, and placidly diftends the Tubes and Veffels of Vegetables, and by that means introduces into them the Matter it bears along with it, conveying it to the feveral Parts of them; where each Part, by a particular Mechanifm in the Structure of it, detaches and affumes thofe Particles of the Mals fo conveyed which are proper for the Nutrition and Augmentation of that Part, incorporating thefe with it, and letting all the reft pafs on with the Fluid; thofe Particles which are either fuperfluous, and more than the parts of the Plant can admit and manage at one time : or that are not fuitable and proper for the Nourifhment of any of the parts of a Plant of that kind, parfing out at the Extremities of it along * Confor. with the Water*. And this latter pag. 125. Office it does likewife to Animals; Water, and other Fluids, ferving to convey the Matter, whereby they are nourifhed, from their Stomachs and

Guts, 


\section{Part III. of the Earth.}

Guts, through the Lacteals and other finer Veffels, to the feveral parts of their Bodies. But the Formation of Animals and Vegetables; being a thing fome-s what foreign to my prefent purpofe, I Thall adjourn the fuller Confideration of it to another Occafion. How far Water is concerned in the Formation of Minerals, will appear more at large in the fucceeding Part of this Work.

That 'tis this Vapour, or fubtile Fluid, II that afcending thus inceffantly out of the Abyfs, and pervading the Strata of Gravel, Sand, Earth, Stone, and the reft, by degrees rots and decays the Bones, Shells, Teeth, and other parts of Animals : as alfo the Trees, and other Vegetables, which were lodged in thore Strata at the Deluge +; this Fluid, by its continual Attrition as it paffes fuc- $+P_{s r t} t_{0}$ ceffively by them, fretting the faid Bodies, by little and little wearing off and diffipating their conftituent Corpufcles, and at length quite diffolving and deftroying their Texture. That yet it hath not this Effect indifferently upon all of them; thofe which happened to be repofed in the firmer and compacter Strata, e. g. of Marble, the clofer kinds of Sand-ftone, Chalk, and

$$
\text { K } 2 \text { the }
$$


the like, being thereby protected in great meafure from its Attacks; it paffing through thefe only in leffer quanticy, and that flowly and with "Vid.cors. difficulty *; fo that its Motion bere 8. Jupra. being more feeble and languid, the Shells and other Bodies enclofed in the e are ufually found very firm and entire, many of them retaining even their natural Colours to this day, though they have lain thus above four thoufand years; and may doubtlefs endure much longer, even as long as thofe Strata, to which they owe their Prefervation, thall themfelves endure, and continue entire and undifturbed: whilft thofe which were lodged in Marle, Sand, Gravel, and the like, more luoje and pervious Matter, are fo rotted and decayed, that they are now not at all, or very difficultly, diftinguifhable from the Marle, or other Matter in which they lye. Not but that there are fometimes found, even in thefe laxer Strata, Shells, Teeth, and other Bodies that are fill tolerably firm, and that have efcaped pretey fafe; but thefe are only fuch as are of a more than ordinary robuft and durable Conftitution, whereby they were enabled the better to with- 


\section{Part III. of the Earth.}

withftand the repeated Affaults of the permeating Fluid, and to maintain their Integrity, whillt the other tenderer kinds perifh'd and were deAtroyed.

That this fame fubtile Fluid exerts the fame power upon the Surface of the Earth, that it does in the Bowels of it: and as it is inftrumental to the Formation of Bodies here ${ }^{*}$, fo is it like-* confer. wife (by a different Operation, which conf. 10. I have not room to defcribe in this ${ }^{\text {supra. }}$ place) of the Deftruction of them; and that Corrofion and Diffolution of Bodies, even the moft folid and durable, which is vulgarly afcrib'd to the Air, is caufed meerly by the ACtion of this Matter upon them; the Air being fo far from injuring and preying upon the Bodies it environs, that it contributes to their Security and Prefervation, by impeding and obftructing the Action of this Matter: and were it not for the Interpofition of the Air, they could never be able to make fo long and vigorous Refiftance as now they do.

That this Subterranean Heat or Fire, 12. which thus elevates the Water out of the $A b y / s$, being in any part of the Earth ftop'd, and fo diverted from its

$$
\mathrm{K}_{3} \text { ordi- }
$$


ordinary courfe, by fome accidental Glut or Obftruction in the Pores or Paffages through which it ufed to afcend to the Surface: and being by that means preternaturally affembled, in greater quantity than úfual, into one place, it caufes a great Rarifaction and Intumefcence of the Water of the Abyfs, putting it into very great Commotions and Diforders: and at the fame time making the like Effort upon the Earth, which is expanded upon the face of the Abyfs, it occafions that Agiration and Concuffion of it, which we call an Earthquake.

That this Effort is in fome Earthquakes fo vehement that it fplits and tears the Earth, making Cracks or Chafmes in it fome Miles in length, which open at the inftants of the Shocks, and clofe again in the Intervalls betwixt them : nay, 'tis fometimes fo extremely violent, that it plainly forces the fuperincumbent strata: breaks them all throughout, and thereby perfectly undermines and ruins the Foundations of them; fo that thefe tailing, the whole Tract, affoon as ever she Shock is over, finks down to rights into the Abyjs underneath, and is fwal- 


\section{Part III. of the Earth.}

lowed up by it, the Water thereof im. mediately rifing up, and forming a Lake in the place where the faid Traet before was. That feveral confiderable Tracts of Land, and fome with Cities and Towns ftanding upon them: as alfo whole Mountains, many of them very large, and of a great height, have been thus totally fwallowed up.

That this Effort being made in all Directions indifferently : upwards, downwards, and on every fide; the Fire dilating and expanding on all hands, and endeavouring, proportionably to the quantity and ftrength of it, to get room, and make its way through all Obftacles, falls as foul upon the Water of the Aby/s beneath, as upon the Earth above; forcing is forth which way foever it can find vent or paffage: as well through its ordinary Exits, Wells, Springs, and the Outlets of Rivers : as through the Chafmes then newly opened: through the Camini or Spiracles of $A m a$, or other near $V_{m b}$ canoes: and thofe Hiatus's at the bottom of the Sea $\uparrow$, whereby the Aby ${ }^{s}+v_{i}$. below opens into it, and communicates eats 3 . with it.

$$
\mathrm{K}_{4} \mathrm{Thet}
$$


That as the Water refident in the Abyfs is, in all Parts of it, ftored with a confiderable quantity of Heat, and more efpecially in tho e e where thefe extraordinary Aggregations of this Fire happen, fo likewife is the Water which. is thus forced out of it; infomuch that, when thrown forth, and mix'd with the Waters of Wells, of Springs, of Rivers, and the Sea, it renders them very fenfibly hot.

That it is ufually expelled forth in vaft quantities, and with great Impetuofity; infomuch that it hath been feen to fpout up out of deep Wells, and fly forth, at the tops of them, upon the face of the ground. With like rapidity comes it out of the Sources of Rivers, filling them fo of a fudden as to make them run over their Banks, and overflow the neighbouring Territories, without fo mueh as one drop of Rain falling into them, or any other concurrene Water to raife and augment them. That it pues out of the Chafmes, opened by the Earthquake, in great abundance: mounting up, in mighty Streams, ro an incredible beight in the Air, and this oftentimes at many Miles diftance from any Sea. That it likewife flies 


\section{Part III. of the Earth.}

forth of the Volcanoes in vast floods, and with wonderful violence. That 'tis forced through the Hiatus's at the bottom of the Sea with fuch vehemence, that it puts the Sea immediately into the moft horrible Diforder and Perturbation imaginable, even when there is not the leaft breath of Wind ftirring, but all, till then, calm and ftill : making it rage and roar with a molt hideous and amazing Noife : raifing its Surface into prodigious Waves, and toffing and rowling them about in a very ftrange and furious manner: overfetting Ships in the Harbours, and finking them to the bottom; with many other like Outrages. That 'tis refunded out of thefe Hiatus's in fuch quantity alfo that it makes a vaft Addition to the Water of the Sea : raifing it many Fathoms higher than ever it flows in the higheft Tides, fo as to pour it forth far beyond its ufual Bounds, and make it overwhelm the adjacent Country; by this means ruining and deftroying Towns and Cities: drowning both Men and Cattel: breaking the Cables of Ships, driving them from their Anchors, bearing them along with the Inundation feveral 
Miles up into the Country, and there running them a-ground: ftranding Whales likewife, and orher great Filh. es, and leaving them, at its Return, upon dry Land.

That thefe $P$ bcenomena are not new, or peculiar to the Earthquakes which have happened in our times, but have been obferved in all Lges, and particularly thefe exorbitant Commotions of the Water of the Globe. This we may learn abundantly from the Hiftories of former Times: and 'twas for this Reafon that many of the Ancients concluded, rightly enough, that they were caufed by the Impulfes and FluEtuation of Water in the Bowels of the Earth; and therefore they very frequently called Neptune soróx日or, as alfo

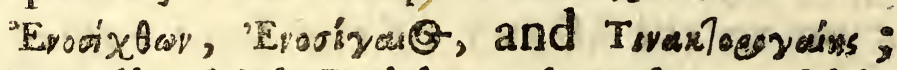
by all which Epithets they denoted his Power of Shaking the Earth. They fuppofed that he prefided over all Water whatever, as wrell that within the Earth, as the Sea, and the reft upon it : and thar the Earth was fupported by Water, its Foundations being laid thereon; on which account it was that they beflowed upon him the Cognomen rasuro, or Supporser of the Earth, and 


\section{Parc III. of the Earth,}

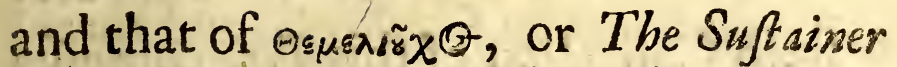
of its Foundations. They likewife believed that he, having a full Sway and Command over the Water, had Power to ftill and compofe it, as well as to move and difturb it, and the Earth, by means of it; and therefore they alfo gave him the Name of 'Aoqdin $\theta$, or The Effablifber; under which Name feveral Temples were confecrated to him, and Sacrifices offered whenever an Earthquake happened, to pacifie and to appeafe him ; requefting that he would allay the Commotions of the Water, fecure the Foundations of the Earth, and put an end to the Earthquake.

That the Fire it felf, which, being thus affembled and pent up, is the Caufe of all thefe Perturbations, makes its own way alfo forth, by what Paffages foever it can get vent: through the Spiracles of the next $V$ ullcano $\|$ : through $\| \operatorname{com}_{\text {f }}$. the Cracks and Openings of the Earth courfect. 13. above-mentioned: through the Apertures of Springs, efpecially thofe of the Therme + : or any other way that it $+v_{i}$ is.

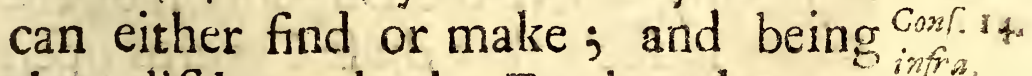
rhus difcharged, the Earthqualke ceafeth, till the Caufe returns again, and 
a freth Collection of this Fire commits the fame Outrages as before.

That there is fometimes in Commotion a Portion of the Abyfs of that vaft Extent, as to thake the Earth incumbent upon it for fo very large a part of the Globe together, that the Shock is felt the fame Minute precifely in Countries that are many hundreds of Miles diftant from each other, and this even though they happen to be parted by the Sea lying betwixt them : nay, there want not Inftances of fuch an univerfal Concufion of the whole Globe as muft needs imply an Agitation of the whole Aby $\beta$.

That though the Abyfs be liable to thefe Commotions in all parts of it, and therefore no Country can be wholly exempted from the Effects of them; yet thefe Effects are no where very remarkable, nor are there ufually any great damages done by Earthquakes, except only in thofe Countries which are mountainous, and confequently fto-

*Vid. ney, and cavernous underneath *; and Part 2. efpecially where the Difpofition of the Conf. S. Strata is fuch that thofe Caverns open into the Abyfs, and fo freely admit and cotertain the Fire, which affembling 


\section{Part III. of the Earth.}

bling therein, is the Caufe of the Shock; it naturally fteering its courfe that way where it finds the readieft Reception, which is towards thefe Caverns; this being indeed much the cafe of Damps in Mines, whereof more by and by. Befides that thofe Parts of the Earth which abound with Strata of Stone, or Marble, making the ftrongeft Oppolition to this Effort, are the moft furiounly thattered, and fuffer much more by it than thole which confift of Gravel, Sand, and the like laxer Matter, which more eafily give way, and make not fo great refiftance; an Event obfervable not only in this, but all other Explofions whatever. But, above all, thofe Countries, which yeild great ftore of Sulphur and Nitre, are by far the mont injured and incommoded by Earthquakes; thefe Minerals conftituting in the Earth a kind of $\mathrm{Na}$ tural Gunpowder, which, taking fire, upon this affembly and approach of it, occafions that murmuring noife, that fubterranean Thunder (if I may fo (peak ) which is heard rumbling in the bowels of the Earth during Earthquakes, and, by the affiftance of its explofive Power, renders the Shock 
much greater, fo as fometimes to make miferable Havock and Deftruction: And 'tis for this reafon that Italy, Sicily, Anatolia, and fome parts of Greece have been fo long and fo often alarmed and haraffed by Earthquakes; thefe Countries being all Mountainous, and $\mathbf{C a}$ vernous, abounding with Stone and Marble, and affording Sulphur and Nitre in great Plenty. But for a more particular Hiftory of the feveral Pbonomena which precede, which accompany, and which follow after Earthquakes: for the Caufes of thofe Phazomena: and for a more exact Account of the Origine, and the Oeconomy of this fubterranean Fire, I muft beg the Reader's Patience till the larger Work be made publick.

13. That Etra, Vefurius, Hecla, and the other Volcanoes, are only fo many spiracles, ferving for the difcharge of this fubterranean Fire; when 'tis thus preternaturally affembled. That where there happens to be fuch a Structure and Conformation of the interiour Parts of the Earth as that the Fire may pafs freely and without impediment from the Caverns, wherein it affembles, unto thefe Spiracles, it then rea 


\section{Part III.}

\section{of the Eartb.}

dily and eafily gets out, from time to time, without thaking or difturbing the Earth; but where fuch Communication is wanting, or the Paffages not fufficiently large and open, fo that it cannot come at the faid Spiracles without firft forcing and removing all $\mathrm{Ob}$ ftacles, it heaves up and hocks the Earth, with greater or leffer Impetuofity, according as the quantity of the Fire thus affembled is greater or lefs, till it hath made its way to the Mouth of the Vulcano; where it rufheth forth, fometimes in mighty Flames, with great Velocity, and a terrible bellowing noife. That therefore there are fcarcely any Countries, that are much annoyed with Earthquakes, that have not one of thefe Fiery Vents; and thefe are conftantly all in Flames whenever any Earthquake happens; they difgorging that Fire, which, whilft underneath, was the caufe of the Dirafter; and were it not for thefe Diversicula, whereby it thus gains an Exit, twould rage in the Bowels of the Earth much more furioully, and make greater havock than now it dotb. So that though thofe Countries, where there are fuch Vulcazos, are ufually, 
more or lefs, troubled with Earthquakes; yet, were thefe Vulcano's wanting, they would be much more troubled with them than now they are: yea in all probability to that degree, as to render the Earth, for a vaft pace around them, perfectly uninhabitable. In one word, fo beneficial are the ee to the Territories where they are, that there do not want Inftances of fome which have been refcued and wholly delivered from Earthquakes by the breaking forth of a new $V$ ulcano there; this continually difcharging that Matter, which, being till then barricaded up, and imprifoned in the Bowels of the Earth, was the occafion of very great and frequent Calamities. That moft of thefe Spiracles perpetually and at all Seafons fend forth Fire, more or lefs; and though it be fometimes fo little that the Eye cannot difcern it, yet even then, by a nearer A pproach of the Body, may be difcovered a copious and very fenfible Heat continually iffuing out.

14. That the Therme, Natural Baths, or Hot Springs, do not owe their Heat to any Colluctation or Effervefcence of the Minerals in them, as fome Natu- 
Part III.

of the Earth.

ralifts have believed : but to the beforemention'd Subterrinean Heat or Fire. That thefe Baths continually emit a manifeft and very fenfible Heat: nay fome of them have been obferved at fome times to fend forth an actual and vifible Flame. That not only thefe, but all orher Springs whatever, have in them fome degree of Heat *, (none "It is ino of them ever Freezing, no not in the deed by of them ever Freezing, no not in the this very longeft and fevereft Frofts) but more heat that efpecially thofe which arife where theirWater there is fuch a Site and Difpofition of is borne the Strata within the Earth as gives from out free and eafie Admiffion to this Heat, Vid. Confs. and favours its Afcent to the Surface; 8. lupra. where perfpiring forth at the fame Outlets with the Water of the Spring, it by that means heats it, more or lefs, as it chanceth to be difpenfed forth in greater or leffer quantity. That as the Heat of all Springs is owing to this fubterraneous Fire, fo wherever there are any extraordinary Difcharges of this Fire, there allo are the neighbouring Springs hotter than ordinary ; witnefs the many Hot-Springs near Etna, Vefuvius, Hecla, and all other Vulcanoes. That the Heat of the Therme is not conftant, and always alike; the 
fame Spring fuffering at fome times a very manifent Failure and Remiffion of its Heat: at others as manifeft an Addition and Encreafe of it; yea fometimes to that Excefs as to make it boil and bubble with extream Heat, like Water when boyling over a common Fire. That particularly during Earth$+V_{i d, C o n s}$. quakes, and Eruptions of Vulcano's $t$, 12.2 and 13. when there is a more copious Acceffion
fupra. of this fubterraneous Fire, the Therme all thereabouts become much hotter than before: yeilding alfo a far greater fupply of Water than they were wont to do: and a murmuring Noife is ufually heard, below them, in the Bowels of the Earth ; all which is occafioned meerly by the then rapid Motion, and Afcent of the Fire, in greater plenty than before, to the Apertures of thefe Springs.

I have now finifh'd the Account of this Section: and was juft going to take off my hand here; but recolleating that in the foregoing Part of this

| Pags 96. Work || I promifed fome turther Proofs of Contrivance in the Structure of the Globe we dwell upon: and fuch too as may fatisfie any fair and unbyals'd Spectator that the framing and Compofition 
Part III. of the Earth.

pofition of it out of the Materials of the former Earth was a work of Counfel and Sagacity : a Work apparently above the higheft reaches of Chance, or the Powers of Nature; and this being a proper place wherein to produce thole Proofs, I thall give fuch Hints of them as the Brevity $I$ am tyed up to will permit me, and then conclude.

I am indeed well aware that the Author of the Theory of the Earth * differs * Lib. it very much from me in Opinion as to 6.9. to 120 this matter. He will not allow that there are any fuch Signs of Art and Skill in the Make of the Prefent Globe as are here mentioned : or that there was fo great Care, and fuch exact Meafures taken in the re-fitting of it up again at the Deluge. He reckons it no other than an huge diforderly Pile of Ruines and Rubbib: and is very unwilling to believe that it was the Product of any Reafoning or Defigning Agent. The Chanel of the Ocean appears to him the most ghaftly thing in Nature, and he cannot at all admire its beawty or elegancy: for 'tis, in his judgment, as deformed and irregular as it is great And for the Caverns of the Earth, the Fiffures and Breaches of the

$$
\text { L } 2 \text { Stratas }
$$


Strata, he cannot fancy that they were formied by any work of Nature, nor by any immediate Action of God, feeing there is neither ufe, that he can difcover, nor beauty in this kind of Conftruction. Then for the Mountains, thefe, he fays, are placed in no order one with another, that can either rejpect $v / e$ or Beauty, and do not confist of any proportion of Parts that is referable to any Defign, or that bath the leaft footfteps of Art or Counfel. In fine, he thinks there are feveral things in the Terraqueous Globe that are ride and unfeemly : and many that are Juperfluous. He looks upon it as incommodious, and as a broken and confused beap of Bodies, placed in no order to one another, nor with any correfpondency or regularity of Parts: and it feems to him nothing better than a rude Lump, and a little dirty Planet. I have given his Opinion in his own Words, though I have upon all like Occafions taken a Shorter Courfe, and contented my felf with giving only the fenfe of others: but this I have done here, leaft any Man fhould fufpect that I miftake the Author's Sentiments, or do not reprefent them fairly. 


\section{Part III. of the Earth.}

Now though it were really fo, that there were fome fuch Eye-fores in our Earth as are here fuggefted : and that we could not prefently find out all the Gayeities and Embelifhments that we might feek for in it, the matter would not be great : and we might very well be contented to take it as we find it. But after all the thing is in truth quite otherwife, and there are none of all thefe wanting: nor any fuch Deformities as are here imagined; but, on the contrary, fo very many real Graces and Beauties, that 'cis no eafie thing to overlook them all. Even this very variety of Sea and Land, of Hill and Dale, which is here reputed fo inelegant and unbecoming, is indeed extreamly charming and agreeable. Nor do I offer this as any private Fancy of my own, but as the common Senfe of Mankind, who are the true and proper Judges in the Cafe, both the Ancients and Moderns, giving their Suffrages unanimoufly herein; and even the Heathens themfelves, have efteemed this variety not only ornamental to the Earth, but a Proof of the Wifdom of the Creator of it, and alledged it as fuch; whereof more in due place.

$$
L_{3} \text { And }
$$


And, as I cannot admit that there is any thing unhandfome or irregular: fo much lefs can I grant that there is any thing incommodious and Artlefs, or ufelefs and Superfluous, in the Globe. Were $I$ at full Liberty to do it here, 'twould be no hard thing to make appear that there ate no real Grounds for any fuch $\mathrm{Charge.}$ For how eafie were it, by taking a minute and diftinct Survey of the Globe, and of the very many and various Limbs and Parts of it, to thew that all thefe are ordered and digefted with infinite Exactnefs and Artifice; each in fuch manner as may beft ferve to its own proper End, and to the ufe of the whole? How eafie were it to fhew, that the Rocks, the Mountains, and the Caverns, againft which thefe Exceptions are made, are of indifpenfible Ufe and Neceffity, as well to the Earth, as to Man and other Animals, and even to all the reft of its Productions? That there are no fuch Blemifhes, no Defects: nothing that might have been altered for the better: nothing fuperfluous: nothing ufelefs, in all the whole Compofition? and fo finally trace out the numerous Footfkeps and Marks of the Prefence and 


\section{Part III. of the Earth.}

Interpofition of a moft wife and intelligent Architect throughout all this ftupendous Fabrick? But I muft referve this for the larger Work, and content my felf for the prefent with only giving fome brief Hints of it in the following Propofitions. Namely,

That 'twas abfolutely neceffary for the well-being both of the Earth it felf, and of all terreftrial Bodies, that fome of the Strata flould confolidate, as they did, immediately after the Subfidence of their Matter at the Deluge: that thefe hould afterwards be broken in certain places : and laftly, that they fhould be diflocated, fome of them elevated, and others depreffed.

That had not the Strata of Stone and Marble become folid *, but the Sand, "Aspart 2. or other Matter whereof they confift, conf.4.

continued lax and incoherent, and they confequently been as pervious as thofe of Marle, Gravel, and the like, the Water which rifes out of the Abyfs, for the Supply of Springs and Rivers, would not have ftop'd at the Surface of the Earth, but march'd directly, and without impediment, up into the Atmofphere, in all parts of the Globe wherever there was Heat enough in

$$
\text { L } 4 \text { the }
$$


the Air to continue its Afcent, and buoy it up; fo that there then muft. needs have been an univerfal failure and want of Springs and Rivers all the Summer-Seafon, in the colder Climes: and all the Year round in the hotter and thofe that are near the Figuaior, where there is much the greateft need of both the one and the other; and this meerly for want of the Interpofition of fuch denfe and folid Strata, to arreft the afcending Vapour to ftop it at the Surface of the Earth: and to collect and condenfe it there.

That though the Strata had become folid, fo as to have condenfed the rifing Vapour, yet if they had not been brot \|As Pert2. ken alfo, \|the Water muft have lain Conn. 6 . eternally underneath thofe Strata, with:out ever coming forth; fo that there then could have been neither Springs nor Rivers for a very confiderable part, or indeed, almoit the whole Earth; the Water, which fupplies thefe, proConf. 8. ceeding out at thofe Breaches*. This fupra. Water therefore would have been wholly intercepted, all lock'd up with in the Earth, and its Egrefs utterly debarr'd, had the Strasa of Stone and Marble remained continuous, and thin... with. 


\section{Part III. of the Earth.}

without fuch Fiffures and Interruptions. That thefe Fiffures have a Atill further ufe, and ferve for Receptacles of Metalls, and of feveral forts of Minerals ; which are arrefted by the $\mathrm{Wa}$ ter in its paffage thither through the Strata wherein the fingle Corpufcles of thofe Metalls and Minerals were lodged + , and borne along with it in- + Part 4 . to thefe Fiffures; where, being by this conf. 5 . means collected, they are kept in ftore for the ufe of Mankind.

That though there had been both folid Strata to have condens'd the afcending Vapour: and thofe fo broken too as to have given free Vent and Iffue to the Water fo condenfed; yet had not the faid Strata been diflocated likewife \|: fome of them elevated, and $\mid$ Part 2. others deprefs'd, there would have Conf.6,7,8. been no Cavity or Chanel to give Reception to the Water of the Sea : no Rocks, Mountains, or other Inequalities in the Globe ; and without thefe, the Water, which now arifes out of it, mutt have all ftagnated at the Surface, and could never poffibly have been refunded forth upon the Earth: nor would there have been any Rivers, or runining Streans, upon the face of 
154 The Natural Hiffory Part III.

the whole Globe, had not the Strata been thus raifed up, and the Hills exalted above the neighbouring Valleys and Plains; whereby the Heads and Sources of Rivers, which are in thofe Hills, were alfo borne up above the ordinary Level of the Earth, fo as that they may flow upon a Defcent, or an inclining Plane, without which they

+ conf. could not flow at all $\uparrow$.

Conf. 8 .

Eupra.

That this Affair was not tranfacted unadvifedly, cafually, or at random: but with due Conduct, and juft Meafures. That the quantity of Matter confolidated : the Number, Capacity, and Diftances of the Fiffures: the Situation, Magnitude, and Number of the Hills, for the condenfing, and difcharging forth the Water; and, in a word, all other things were fo ordered as that they might beft conduce to the End whereunto they were defigned and ordained: and fuch provifion made that a Country fhould not want fo many Springs and Rivers as were convenient and requifite for it: nor, on the other hand, be over-run with them, and afford little or nothing elfe; but a Supply every where ready, fuitable to the Neceftries and Expences of each 


\section{Part III. of the Earth.}

Climate and Region of the Globe. For example, thofe Countries which lye in the Torrid Zone, and under or near the Line, where the Heat is very great, are furnifhed with Mountains anfwerable: Mountains which both for Bignefs and Number furpals thofe of colder Countries as much as the Heat there furpaffes that of thofe Countries. Witnefs the Andes, that prodigious Chain of Mountains in Soutb America: Atlas in Africa: Taurus in Afra: the Alpes and Pyrenees of Europe, to mention no more. By thefe is collected and difpenfed forth a quantity of Water proportionable to the Heat of thofe Parts; fo that although, by reafon of the Excefs of this Heat there, the Evaporations from the Springs and Rivers are very great, yet they, being, by thefe larger Supplies, continually ftock'd with an Excefs of Water as great, yeild a Mafs of it for the ufe of Mankind, the Inhabitants of thofe Parts, of the other Animals, and of Vegetables, not much, if at all, inferiour to the Springs and Rivers of colder Climates. That befides this, theWaters thus evaporated and mounted up into the Air, thicken and cool 
it, and, by their Interpofition betwixt the Earth, and the Sun, skreen and fence off the ardent Heat of it, which would be otherwife unfupportable: and are at laft returned down again in copious and fruitful Showers to the fcorched Earth; which, were it not for this remarkably Providential Contrivance of Things, would bave been there perfectly uninhabitable: laboured under an eternal Drought: and have been continually parched and burnt.

To this former Section I thall add; by way of Appendix,

I. A Differtation concerning the Flux and Reflux of the Sea : and its other Natural Motions; with an Account of the $C_{\text {auf }}$ of thofe Motions: as alfo of the Exd and V/e of them: and an Enquiry touching the Canfe of the Ebbing and Flowing, and fome other uncommon Pbanomena of certain Springs.

2. A Difcourfe concerning the Saltneß of the Sea.

3. A Difcourfe concerning $W$ ind the Origin, and Ufe of it in the Natural World. 


\section{Pare III. of the Earth.}

\section{PART III. SECT.II.}

Of the Univerfality of the Deluge. of the Water which effected it. Together with fome further Particulars concerning it.

T the precedent Section I confider the prefent and natural State of the Fluids of the Globe. I ranfack the feveral Caverns of the Earth: and fearch into the Storehoufes of Water; and this principally in order to find out where that mighty Mafs of Water which overflowed the whole Earth in the days of Noab, is now beftowed and concealed: as alfo which way'tis at this time ufeful to the Earth and its Productions, and ferviceable to the prefent Purpofes of Almighty Providence.

Such a Deluge as that which Mofes reprefents, whereby All the bigh Hills that were under the whole. Heaven were covered $\uparrow$, would require a portentous + Gen.7. quantity of Water; and Men of $\mathrm{Cu}_{-}{ }^{19 .}$ riofity, in all Ages, have been very 
much to feek what was become of it, or where it could ever find a Refervatory capable of containing it. "Tis true there have been feveral who have gone about to inform them, and fet them to rights in this Matter ; but for want of that Knowledge of the prefent Syftem of Nature : and that infight into the Structure and Conftitution of the Terraqueous Globe, which was neceffary for fuch an Undertaking, they have not given the Satisfaction that was expected. So far from it that the greateft part of thefe, feeing no where Water enough to effect a General Deluge, were forced at laft to mince the Matter, and make only a Partial one of it ; reftraining it to one fingle Country : to $A f a$, or fome leffer portion of Land; than which, nothing can be more contrary to the Mofaick Narrative.

For the reft, they had recourfe to Shifts which were not much better; and rather evaded than folved the Difficulty; fome of them imagining that a quantity of Water, fufficient to make fuch a Deluge, was created upon that Occafion, and, when the bufinefs was done, all disbanded again and annihila- 


\section{Part III. of the Eartb.}

ted. Others fuppofed a Converfion of the Air and Atmofphere into Water, to ferve the turn. Many of them were for fetching down I know not what fupercoeleftial Waters for the purpofe. Others concluded that the Deluge rofe only fifteen Cubits above the Level of the Earth's ordinary' Surface, covering the Valleys and Plains, but not the Mountains : all equally wide of Truth, and of the Mind of the Sacred Writer. One of the laft Undertakers of all feeing this, began to think the Caufe defperate; and therefore, in effect, gives it up. For confidering how unfuccelsful the Attempts of thofe who were gone before him had proved: and having himfelf $\|$ alfo employed bis $\|$ Theory of laft and atmoft endearours to find out Waters for the Vulgar Deluge : having Earth, 1. I. c. 2 . multered up all the Forces he could think of, and all too little: The Clouds above, and the Deeps below, and in the bopels of the Earth; and the fe, fays he, are all the Stores we bave for Water, and Moles directs us to no otber for the Canfes of the Deluge: he prepares for a Surrender, afferting, from a miltaken and defective Computation, that all the $e$ will not come up to near the 
quantity requifite: and that in any known parts of the Univer $e$, to find $W$ dter fufficient for this effect, as it is generally explained and underftood, is, he thinks, impolfible : that is, fufficient to caufe a Deluge, to ufe his own Words, overflowing the whole Earth, the whole Circuit, and whole Extent of it, burying all in Water, even the greateft. Mountains: which is, in plain terms, fuch a one as was explained and underftood by Mofes, and the Generality of Writers fince.

Having therefore thus over-haftily concluded that fuch a Deluge was impoffible: and that all Nature could not afford Water enough to drown the whole Globe, if of the Circuit and Extent that now it is : he flies to a new Expedient to folve the Matter, and fuppores an Earth of a Make and Frame much like that imaginary one $\|$ Princ. of the Famous Monfieur Des Ciartes $\|_{2}$ pbilof. 1. 4. which he makes to fall all to pieces, at the Deluge, and to contract it felf into a leffer room, that the Water might the better furround and encompals it.

The fober and better fort of the Standers-by, and thofe who were Well-wifhers to Mofes, began to be under 


\section{Dâronit.}

undér fóme Concèrn and Uneafinels to fee him thus fet afide only to make way for a new Hy pothelis: and 10 ferious and weighty a Matter, as is this Tradition of the Univeral Deluge, plac'd after all upon fo very uniteady a Bottom. But that Concern encreas'd when they further heard him fo zealoufly decrying all former Notions of a Deluge: refufing to grant one upon any Terms but his own: and fo peremptorily declaring, That all other mays affigned for the Explication of Noab's Flood are falfe or impoffible. This was to reduce the Thing to a very great Streight : and furely an expofing and venturing of it a little too far. For if all the other Ways be falfe and imporfible, fhould this, the only one left, prove at laft fo likewife, the Opinion of a Deluge would be left very precarious and defencelefs, and we might either believe or disbelieve it at pleafure; nay the negative part would of the two have much the Advantage, there being no reafonable Foundation to believe that the Deluge did come to pafs this way.

Some Men there are who have made a very untoward ufe of this, and fuch 
a one that I am willing to perfuade my felf he never intended they fhould; yet it were to have been wifhd that he had been fomewhat more wary. Thefe cryed up this Computation of the Water as indifputable and infallible : and then boldly gave out that fuch a Deluge as that defcribed by Mofes was altogether incredible, and that there never was nor could be any fuch Thing. Nothing was talk'd of amongft them under Mathematical Demonftrations of the Fallhood of it; which they vented with all imaginable Triumph, and would needs have it that they had here fprung a frefh and unanfwerable Argument againft the Authenticknefs of the Mofaick Writings; which indeed is what they drive at, and a Point they very fain would gain.

For my part, my Subject does not neceffarily oblige me to look after this Water: or to point forth the place whereinto 'tis now retreated. For when, from the Sea-fhells, and other Remains of the Deluge, I thall have given undeniable Evidence that it did actually cover all Parts of the Earth, it muft needs follow that there was then Water enough to do it, wherever it 


\section{Part III. of the Eartho}

may be now hid, or whether it be ftill in being or not. Yet the more effectually to put a ftop to the Infults and Detractions of thefe vain Men, I res folved to enter a little farther into the Examination of this Matter; and that produced the former Section of this $3^{\mathrm{d}}$ Part; wherein I enquire what proportion the Water of the Globe bears to the Earthy Matter of it ; and upon a moderate Eftimate and Calculation of the Quantity of Water now actually contained in the Abyfs, I found that this alone was full enough, if brought out upon the Surface of the Earth, to cover the whole Globe to the height affigned by Mofes; which is, fifteen Cubits above the Tops of the highent Mountains *; the Particulars of which * $\mathrm{Gem}$. viit.

Calculation, thall be laid before the 20 .

Reader at length in the Larger Work; for any one will eafily fee that there is fo great an Apparatus of Things only previous, which muft needs be adjufted before I can come to the Calculation it felf, that to defcend to Particulars bere, further than I have already \| done, $\|$ conf. would not only carry this Difcourfe out Sect. I. beyond all reafonable Bounds, and Conf. Is. make the Parts of it difproportionate 
to each other, but, which is not lefs to be thought of, would be an Anticipation of the Otber Work.

This done, I again fet afide the $\mathrm{Ob}$ fervations about the Fluids of the Globe, introduced upon this Occafion in the other Section, as now of no furcher ufe: and reallume the Thread of the other Obfervations which I propofe at the Beginning of this Work; and from them I thew,

I. That the Deluge was Vniverfal, and laid the whole Earth under Water: covering all, even the higheft, Mountains, quite round the Globe.

2. Thar at the time of the Deluge the Water of the Ocean was firft born forth upon the Earth: That it was immediately fucceded by that of the $A b y / s$; which likewife was brought out upon the Suriace of the Globe.

3. That upon the Difruption of the Strata: and the Elevation of fome, and Depretion of others of them, which followed after that Difruption, towards the latter end of the Deluge $\downarrow$, this

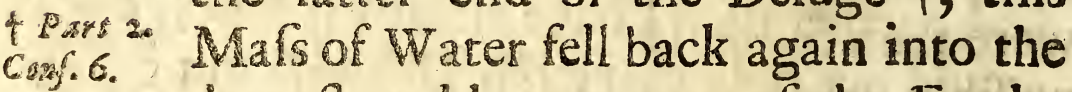
depreit and lower parts of the Earth: into Lakes and other Cavities : into the Alvews of the Ocean: and through the Fiffures 


\section{Part III. of the Earth. 165}

Fiffures whereby this communicates with the Ocean *, into the Abyfs; ${ }^{*}$ Serz. ז. which it filled till it came to an Aqui. ${ }_{\text {conf }} .2$. librium with the Ocean.

That there muft have pafs'd a con- 4. fiderable number of $\Upsilon_{\text {ears }}$ betwixt the Creation and the Deluge: and moft probably about fo many as Mofes hath affigned.

That the Deluge commenc' $d$ in the 5 . Spring-feafon: the Water coming forth upon the Earth in the Month which + Confer. we call May $\uparrow$.

That not only Men, Quadrupeds, 6. Birds, Serpents, and Infeets; the Inhabitants of the Earth and Air: but the far greateft part of all kinds of $F i j h$ likewife, the Inhabitants of the Sea, of Lakes, and of Rivers, fuffered under the Fury of the Deluge, and were killed and defroyed by it.

That the Deluge did not happen 7 . from an accidental Concourfe of Natural Caufes as the Author above-cited is of Opinion $\|$. That very many Things $\|$ Theory of were then certainly done, which never the Earth poffibly could have been done without 1, ., c. 6. \&. polfibly could have been done without $\&$ ic the Affiftance of a Supernatural Power. That the faid Power acted in this Matter with Defgn, and with the higheft

$$
\mathrm{M}_{3} \text { Wifdoms. }
$$


Wifdom. And that, as the Syftem of Nature was then, and is ftill, fupported and eftablifhed, a Deluge neither could then, nor can now, happen naturally.

I clofe up this Section with two additional Difcourfes.

The firft concerning the Migration of Nations : with the feveral Steps whereby the World was re-peopled after the Deluge by the Pofterity of Noah, and particularly that mighty Tract of America. Wherein I hall make out, I. Who they were that firft peopled it. 2. When they departed thitherwards. 3. What Courfe they took: and by what means both Men and Beafts, as well Serpents and the other noxious and more intractible kinds of them, as the more innocent and ufeful, got thither. 4. Whether there remain any certain Veftigia of a Tradition, in the Writings of the Ancients, about thefe Americans: and what Country they intended under the Name of $A$ lantis. 5. Whether the Pbamicians, or any other Nation of the old World, maintained anciently any Commerce or Correfpondence with them. 6: How it happened that both the Inlabitants 
Part III. of the Earth.

of that, and of our World, loft all memory of their Commigration hence. 7. Whence came the Difference in Perfon, or in the external Shape and Lineaments of the Body : in Language: in Dyet, and manner of Living: in Clothing: in Arts and Sciences: in Cuftoms Religious, Civil, and Military, betwixt thefe Americans, and their old Relations in Afra, Europe, and Africa. With Animadverfions on the Writings of Grotius, De Laet, Hornius, and others, upon this Subject.

The Second concerning the unanimous Tradition of an Univer al Deluge amongft all the moft ancient Gentile Nations : particularly the Sicythians, the Perfians and Babylonians: the Bithynians, Phrygians, Lydians, Cilicians, and other People of Afa Minor: the Hierapolitans, Phezicians, and other Inhabitants of Syria: the Egyptians, Cartbag nians, and other African Nations: the moft ancient Inhabitants of the feveral Parts of Greece: and of the other Countries of Europe : the old Germans: the Gauls: the Romans : the ancient Inhabitants of Spain, and even the Bri. tains themfelves, the firft Inhabiters of this Inand: Proving that the great De-

$\mathrm{M}_{4} \quad$ vaftation 
vaftation and Havock the Deluge taade, both of the Earth it Felf, of the Generafity of Mankind, of Brutes, and alt Animals, had wrought a deep and very. fenfible Inpreffion upon the Minds of thefe ancient Nations, who fived nearer to the time of it That they had not only a Nembory and Táadition of it in general and at large but even of feveral the moff remarkable particular Accidents of it likewife; which they handed downwards, to the fuc ceeding Ages, for fome time, with Notes of the greateff Terror, Atazement, and Confternation expreffible? That it was commenterated chiefly by certain Religious Rites and Ceremonilies ufed by them in the Wotfhip of the EARTH which Superfitious Adoration was firft inflituted upon this Occafion in thofe fimple and ig t vil. norant Ages t, and addrêfs di co the pag.55. Earth, not only exprefly and by Name,

but allo under the feigned a rowed Names of Alargatis, Dexceto. Aftarte, Dear Syria, Herthis, Ifis, Magna Mater, Cybele, and Rbsa, with Teveral more; by all which, they in. rended the Earth. That at length the Tradition, for wane of Tetrers, which 


\section{Păre II. of tbe Earth.}

which were not then invented, or fome other like means to preferve it, wearing out, and the reafon of the Inftitution of this Worfhip being by degrees forgot, the After-Ages perverted it to a fomewhat different Senfe and Intention: fuppofing that this was only a reverential Duty and Gratitude paid to the Earth as the Common Parent of Mankind, and becaufe both Man, and all other Creatures proceed out of it; by which means the true Notion of the Inftitution rubeing loft, the Tradition of the Deluge, which was couched unden it, was alfo thereupon at length fufpended and loft; none of all thefe many Nations, in the latter Ages of the World, having any Memory or Knowlledge of it, befides what they afterwards urecovered from the Jews and ancient Chriftians, who had it from the Writings of Mofes. In Greece indeed there were fome other Accidents which perplex'd and impeded the Tradition of it in that Country, whereof Thave already $\$$ given fuch Hints as + part $\mathrm{I}$.

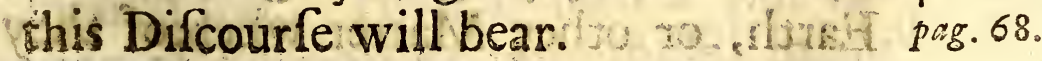




\section{PA R T IV.}

Of the Origin and Formation of Metalls and Minerals.

T $T^{H a t}$ I can advance, with competent Certainty, about the Fluids of the Globe: the Sea, Springs, Rivers, and Rain, I propofe in the immediately foregoing, or Third Part of this Eflay: As in the Second Part of it I difpatch the Solids: Stone, Marble, Gravel, and all the other Terreftrial Matter of it, which is digefted into Strata. That Part therefore comprehends the far greater Thare of that Matter; and indeed all, excepting only Metalls and Minerals; which are found much more fparingly and in leffer Parcels; being either enclofed in thofe Strata (lying amongft the Sand, Earth, or other Matter whereof they confift) or contained in their perpendicular Fiffures. And the fe remaining 


\section{Part IV. of the Earth.}

ftill to be confidered, I have allotted this Fourth Part to that Purpofe.

To write of Metalls and Minerals intelligibly and with tolerable perfpicuity, is a Task much more difficule than to write of either Animals or Vegetables. For thefe carry along with them fuch plain and evident Notes and Characters either of Difagreement, or Affinity with one another, that the feveral Kinds of them, and the fubordinate Species of each, are eafily known and diftinguifh'd, even at firft fight; the Eye alone being fully capable of judging and determining their mutual Relations, as well as their Differences, But in the Mineral Kingdom the Matter is quite otherwife. Here is nothing regular, whatever fome may have pretended: nothing constant or certain: infomuch that a Man had need to have all his Senfes about him: to ufe repeated Tryals and Infpections, and that with all imaginable Care and Warinefs, truly and rightly to difcern and diftinguifh Things, and all little enough too. Here is fuch a vaft variety of Phanomena, and thofe, many of them, fo delufive, that 'tis very hard to efcape Impofition and Miftake.

Colour, 
Colour, or outward Appearance, is not at all to be trufted. A common Marcafite or Pyrites thall have the Colour of Gold moft exactly : and Thine with all the Brightnefs of it, and yet upon tryal, after all, yield nothing of worth, but Vitriol, and a little Sulphur: whilft another Body, that hath only the Refemblance of an ordinary Peble, thall yield a confiderable quantity of Metallick and valuable Matter. So likewife a Mars, which, to the Eye, appears to be nothing but meer fimple Earth, Thall, to the Smell or Tafte, difcover a plentiful Admixture of Sulphur, Alum, or fome other Mineral. Nor may we with much better Security rely upon Figure, or external Form. Nothing more uncertain and varying. Tis ufual to meet with the very fame Metall or Mineral; naturally Shot into quite different Figures : as 'tis to find quite different kinds of them all of the fame Eigure. And a Body, that has the fhape and appearance of 2 Diamond, may prove, upon Examination, to be nothing but. Cryftal, or Selenitis: nay perhaps only common Salt, or Alum, naturally cryftallized and fhot into that Form. 
So likewife if we look into their $5 i-$ twation, and place in the Earth; rometimes we find them in the perpendicular Intervalls: fometimes in the Bodies of the Strat a, being interfpers'd amongft the Matter whereof they confift: and fometimes in both; even the gemmeous Matter it felf, (if I may fo fpeak ) with this only difference, that thofe Gemms, e.g. Topazes, Amethyits, or Emeralds, which grow in the Fiffures, are ordinarily cryltallized, or fhot into angulated Figures: whereas in the Strata they are found in rude Lumps, and only like fo many yellow, purple, and green Pebles. Not but that even thefe that are thus lodged

in the Strata are al- + The Cryfallized Bodies found fo fometimes found is the perpendicular intervashs cryftallized to and are eafily known from thofe wabich cryltallo are lodged in the Strata, even by in form of Cubes, one wobo did not take them thence, or obferve them there. The former bave always their Root, (as the Fervellers call it) which is only the Abruptaefs at that end of the Body 20bereby it adbered to the Stone, or fides of the Intervalls, wobich Abruptnefs is caufed by its being broke off from it. Thofe wobich are found in the Strata of Earth, Sand, or the like, (baving lain loose therein) are intire, adad reant that Mork of Adbelion: but thofe which are inclofed ing Stone, Marble, or fuch otber Joiid Matzer, being diffcultly feparsble from it, becruse of its Adhefan to all fides of them, have coms monly fome of that watter fiill adhering to them, or at least Mavks of its Abruption from them, on all their Sides; wherein thefe differ from thofe found in the perperdicular lntervalls, they, adiseriss. *o we have noted, by only one eng. Vid. Conf.6. \&c. infra.

Rhombs, 
" Vid. Rhombs, and the like *. Or if we Conf. 2. have refpect to the terreftrial Matter infra.

wherein they lye in thofe Strata, here we fhall meet with the fame Metall or Mineral embodied in Stone, or lodged in Cole, that elfewhere we found in \|vid. Marle, in Clay, or in Chalk \|. Confect. 3. infra.

As much Inconftancy and Confufion is there in their Mixtures with each other, or their Combinations amongtt themfelves; for 'tis rare to find any of them pure, fimple, and unmixt: but Copper and Iron together in the fame Mals: Copper and Gold : Silver and Lead : Tin and Lead: yea fometimes all the fix promifcuouny in one Lump. "Tis the fame alfo in Minerals; Nitre with Vitriol: Common Salt with Alum: Sulphur with Vitriol: and fometimes all five together. Nor do Metalls only fort and herd with Metalls in the Earth : and Minerals with Minerals : but both indifferently and in common together: Iron with Vitriol, with Alum, with Sulphur: Copper with Sulphur, with Vitriol, \&rc. yea Iron, Copper, Lead, Nitre, Sulphur, Vitriol, and perhaps fome more in one and the fame Mafs. In a word, the only ftanding Telt, and difcriminative Characteriftick 
Part IV. of the Eartb.

racteriftick of any Metall or Mineral mult be fought for in the conftituent Matter of it: and it muft be firft brought down to that before any certain Judgment can be given. And when that is once done, and the feveral kinds feparated and extracted each from the other, an homogeneous Mafs of one kind is eafily diftinguifhable from any other: Gold from Iron: Sulphur from Alum: and fo of the reft. But without $t$ his, fo various are their Intermixtures, and fo different the Face and Appearance of each, becaufe of that Variety, that farcely any thing can be certainly determined of the particular Contents of any fingle Mafs of Ore by meer Infpection. I know that by Experience and Converfation with the fe Bodies, in any Place or Mine, a Man may be enabled to give a near ConjeEture at the Metallick or Minẹral Ingredients of any Mafs commonly found there; but this meerly becaufe he hath before made tryal of other like Maffes, and thereby learned what it is they contain. But if he remove to another place, though perhaps very little diftant, 'tis ten to one but he meets with to different a face of Things, that he'll 
be there as far to feek in his Conjectures as one who never before faw a native Ore, untill he hath here made his tryals as before, and fo further informed himfelf in the matter.

Metalls being fo very ufeful and ferviceable to Mankind, great Care and Pains hath been taken, in all Ages, in fearching after them, and in feparating and refining of them. For which reafon 'tis that the fe have been accurately enough diftinguif' $d$, and reduced to fix kinds, which are all well enough known. But the like pains hath not been taken in Minerals; and therefore the Knowledge of them is fomewhat more confufed and obfcure. Thefe have not yet been well reduced, or the number of the fimple original ones rightly fixt; fome, which are only Compounds, the Matter of two or more kinds being mix'd together, and, by the different Proportion and Modulation of that Matter, varioully difguifed and diverfifyed, having been reputed all different kinds of Minerals, and thereby the Number of them unneceffarily multiplied. Of this we have an Inftance in the Gemm-kind; where, of all the many forts reckoned 
Part IV. of the Earti.

up by Lapidaries, there are not above three or four that are Original; their Diverfities, as to Luftre; Colour, and Hardnefs, arifing from the different Admixture of other adventitious Mineral Matter. But the farther and clearer Adjuftment of this Affair I am conftrained to adjourn to the larget Treatife.

In the mean time 'tis fufficient for my prefent Defign, to remark in general, that thofe Minerals and Ores of Metalls which are repofited in the Bodies of the Strata, are either found in Grains, or fmall Particles, difperfedly intermixd with the Corpufcles of Earth, Sand, or other Matter of thofe Strata: or elfe they are ama $\int^{\prime} d$ into Balls, Lumps, or Nodules. Which Nodules are either of an irregular and uncertain Figure, fuch as are the common Pyrite: Flints, Agatis, Onyx's: Pebles, Cornelions, Fapers, and the like : or of a Figure fomewhat more regular and obfervable, fuch as the Belemnites: the Teveral forts of Mineral Coral, of the Stelecbites, and of the Lapis Mycetoides\|:\| Vulgarly. the Aftroites, or Starry Stone, as well ${ }^{2}$ call' a Fuar that fort with the Promivient, as that with the Concave Stars : the Selenites:

$$
\text { N the }
$$


the Echinated Cryftalline Balls, with many more analogous Bodies.

Thofe which are contained in the Perpendicular Intervalls of the Strata are, either fuch as are there accumulated into a rude Heap, without any particular Form or Order, being only included betwixt the two oppofite Walls or Sides of the faid Intervalls, which they wholly or partly fill, as there is a greater or lefs quantity of them; in which manner Spar is ufually found here in, and other Minerals, as alfo the common Ores of Lead, Tin, Irom, and other Metals: or elfe fuch as are of fome obfervable Figure; of which fort are the Sparry Stiria, or Iceycles called

"Or ra. Stalactita* : the Native Saline Iceycles, ther Stago- or Sal Stalacticum: the Vitriolum StalaEticum Nativum : the Vitriolum Capillare: the Alumen Stalacticum, and $C_{c}$ : pillare: Minera ferri Stalacfica, which, when feveral of the Cylindrick Stirice are contiguous, and grow together into one Shieaf, is called Brub-From-Ore: Argentum Arborefcens, o Capillare: as alfo the Cryftallized Ores and Minerals, e. g. the Iron-Rhombs, the Tin Grains: the Mundick-Grains: Cryftallized Nasique Salt, Alum, Vitriol, and Sulphur: 


\section{Part IV. of the Eartho}

of which fort likewife are the Gemms or Stones that are here fhot into Cubes, into Pyramidal Forms, or into angulated Columns, confifting of fix Sides, and mucronated or terminating in a Point : being either opake, or pellucid: or partly pellucid, and partly opake, and coloured, black, white, grey, red, purple, blue, yellow, or green: e. g. Cryftall, the P Seudu-cadamantes, the Corni h-Stones, the Briftom-Stones, Cryfallized Sparrs, the Iris, the Amethy $t_{\text {. }}$ the Saphire, the Topaz, the Emerauld, and feveral others.

My Bufinefs here is to enquire into the Origin and Production of thefe Metallick and Mineral Bodies : to enquire how they came into this condition, and attained thefe Figures. And as my Obfervations have been the light whereby I have hitherto fteered my Courfe, fo I here betake my felf unto them again ; and 'tis from them that I prove,

That as the more grofs and maflive I. parts of the Terreftrial Globe : the Strata of Stone, Marble, Earth, and the reft, owe their prefent Frame and Order to the Deluge * fo likewife do Metalls and Minerals too; the far ${ }^{*} \mathrm{~V} i \%$.

$$
\mathrm{N}_{2} \text { grea er }
$$


greater part of them, I mean all thofe which we now find lodged in thofe

- Sycra amongft the Sand, Earth, oc. being actually repofed therein during the time that the Water covered the Earth: and the Earth it felf then put - into fuch a condition that the reft, I mean thole we now find in the perpeadicular Intervalls, thould be collected thither by degrees, and be formed - vidconf almolt of courfe, meirly by the ordi4. add 5. nary Motion of the Water, and its ing in

2. That whilft the Corpufcles of Metalls and Minerals, together with thofe of Stone, Marble, Cole, Chalk, and the like courfer Matter: as alfo the Shells, Teeth, and orher parts of Animals and Vegetables: were fuftained in the Wa-

1.Part 2. ter, at the Deluge $\uparrow$; after fome time, Canfer.2. Elat the violence of the Hurry and Commorion was over, and the Water conve to a ftate fomewhat more calm and fedate, fuch of thofe Corpufcles, as happened to occurr or meet together, affix'd to each other : and, many of chem convening, uniting, and combining into one Mafs, formed the Merallicl and Mineral Balls or Nodules which we now find. 


\section{Part IV. of the Easth.}

That all Metallick and Mineral Nodules whatever: as well thofe which are in rude Lumps, fuch as the common Pyrite, Flints, Agates, Onyxes, Pebles, Jafpers, Cornelions, and the like: as thofe which are of a more $r$. gular and obfervable Shape, fuch as the Selenites, Belemnites, Srelechires, Mineral Coral: and, in one word, all others whatfoever, were formed at this time and by this means.

That in fuch parts of the Water where the Corpufcles fo fuftained chanced to be all of the fame kind * : or, at "Vid. Pars leaft, where there were fewer kinds $5 . \operatorname{coms} \mathrm{A}$. or varieties of them, the Nodules, which were thus formed out of them, were more fimple, pure, and homogeneous, as are the Selenites, and fome kinds of Pebles and Flints, to name no more: But where (as indeed ir generally fell out) there happened to be a greater variety of Corpufcles, as fuppofe of Sulphur, of Vitriol, of Alum, of Iron, of Copper, or whatever elfe, fuftained promifcuoufly together, there the Nodules, formed out of them, were mixt, and confifted of a greater variety of Matter confufedly affociated into the fame Lump. Of this the Pyise may 
may ferve for an Example; whereof fome yield Iron, Sulphur, and Vitriol: orhers Copper and Alum : yea fome of them contain all thefe, and feveral more, in the fame Nodule.

That the Bones, Teeth, Shells, and other like Bodies, being fuftained in the Water together with thefe Metal-

$\|$ Part 2. lick and Mineral Corpufcles $\|$, and the corr. 2. faid Corpufcles meeting with, and hitting upon thofe Bodies, they affix'd unto them, and became conjoyned with them: fome of them (though this very rarely) paffing into their Pores and Interftices : others adhering in Lumps, or Maffes, to their Out-fides, and indeed oftentimes combining in fuch numbers upon the exteriour Surface of the Shell, Tooth, Eoc. as wholly to cover and involve it in the Mafs they together conftituted: and others of them entering into the Cavities of the Echini, Cochicea, Conche, and other Shells, till they had quite filled them up; thofe Shells, by that means, ferving as Proplafmes, or Moulds, to the Matter which fo filled them, limiting and determining both the Dimenfions and Figure of it. That accordingly we at this day find fome few of thefe 
Part IV. of the Earth.

foffil Shells, and other Animal Subftances, with Iron-ore, Spar, Vitriol, Sulphur, and the like, intruded into their Pores: but far greater numbers of them with Lumps of Flint, Ores of Metalls, and Minerals, growing firmly to the Out-fides of them, and oftentimes in fuch quantity as that the Shell or Tooth is wholly covered by thofe Minerals, being immers' $d$ or included in the Mafs they conftitute; infomuch that 'tis very ufual, upon breaking Flints, Pyrito, \&c. to find Pectines, Conche, and the like, enclofed, even in the very middle of them. As common is it to find Ecbini, Cocblex, Conche, and other Shells, having their Cávities fill'd up with Ores of Metalls, Flint, Spar, Native Vitriol, Sulphur, and other Minerals. Not but that thefe Minerals many times furvive the Shells which gave them their Forms, and are found even after they are rotted and difap. peàred; for though, when lodged in Chalk; or the like clofe Matter, which preferves and fecures them againft external Injuries, thefe Shells are conffantly found upon, and actually invefting the Flint, Spar, or other Mineral, and are commonly as fair and

$\mathrm{N}_{4} \quad$ entire 
entire as any of their fellow Shells at Sea: yet when they happened to be lodged amongtt Sand, Gravel, or the like laxer Matter, the Shells are ufual"Vid.part ly perifh'd and gone *, and fo the 3. Serf.r. I. Flint, Spar, oc. left uncover'd. In which cafe the faid Flint, Spar, or other Mineral, is of a conftant, regular, and fpecifick Shape, as is the Shell whence it borrows both that Shape, and indeed its Name; thefe being the Bodies which are called, by Natura\|conf. lifts, Echinite, Cocblite, and Cochita \|, Part 5. as refembling the Shells of thofe names: conf. 5. and truly many of them very nearly, they having taken the Impreffes of the Infides of thefe Shells with that exquifite Nicenefs as to exprefs even the frmalleft and fineft Lineaments of them: infomuch that no Metall, when melted and caft in a Mould, can ever poffibly reprefent the Concavity of that Mould with greater Exactnefs than thefe Flints, and other Minerals, do the Concavities of the Shells wherein they were thus moulded.

3. That at length all this Metallick and Mineral Matter, both that which conrimued afunder, and in fingle Corpufcles, and that which was amals'd and 


\section{Part IV. of the Earth.}

concreted into Nodules, $\int u b f$ fded down to the bottom : at the fame time that did the Shells, Teeth, and other like Bodies, as alfo the Sand, Cole, Marle, and other Matter whereof the Strata of Sand-ftone, Cole, Marle, and the reft are for the molt part compoled $\uparrow,+{ }_{\text {Part }}$ Conf $_{\text {. }}$ and fo were included in, and lodged ${ }_{\text {Conf } \int_{0}}{ }_{3}$. amonget, that matter.

That in regard that both the ordinary Terreftrial Matter, and the Mineral and Metallick Matter which was affumed up into the Fluid was different in different parts of it, being in fome places all chiefly of one kind, fuppofe Sand : in others of a different kind, e.g. Chalk: and in others of feveral kinds together, as Sand, Chalk, and many more: and there being no other Place or Apartment in the Globe affigned to any of this Matter than that whereinto its own natural Gravity bore it, which was only diręly downwards, whereby it obtained that place in the Globe which was juft underneath that part of the Fluid where it was fuftained when the Subfidence began; it thence happened that the Strata, which were afterwards conftiruted by this Matter thus fubfiding, 
are alfo different in different places: in fome all, or molt of them, of Sandftone: in others of Chalk : and in others of both Sand-ftone and Chalk, and perhaps many more, lying each upon other. And the Cafe of Metalls and Minerals being the fame, 'tis for that reafon that in fome places we now get Iron, or Vitriol; but no Copper, or Alum : in others we find thefe, but not thofe : and in others both thefe, and thofe, and perhaps many more.

That the Place, both of the feveral forts of Terreftrial Matter, and of Metalls and Minerals, whilf fuftained in the Fluid, being thus contingent and uncertain, their Intermixtures with each other, and with the Terreftrial Matter, in the Sediment, or Strata, which fubfiding they together compofed, muft confequently be uncertain likewife; that Metall or Mineral, of whatever kind it chanced to be, which was fuftained in any part of the Fluid, fetling only directly downwards, was lodged amongft the Terreftrial Matter which chanced to be fuftained together with it in the fame part, of what kind foever that Matter was. And accordingly we now find them uncertainly 


\section{Part IV. of the Earth.}

mixt : the fame Metall or Mineral lodged; in fome places, in Stone : in others, in Cole : and in others, in Clay, Marle, or any other Matter indifferently $t_{0}+{ }_{\text {Pag. }}^{+}$V 74. And as we find the fame Metall or Mi- Pag. I neral lodged amongft different forts of the common Terreftrial Matter, fo do we, for ftill the fame reafon, alfo find different kinds of Metalls and Minerals, Copper, Iron, and Sulphur, Tin, Lead, and Vitriol, with feveral more, lodged all confufedly together in the very fame fort of Terreftrial Matter $\|.\| V_{i d}$.

That the quantity of the Metallick fupra.

or Mineral Matter taken up into the Fluid was various and uncertain : there being in fome parts little or perhaps none of it: in others a very great abundance. And fo we at this day find it $;$ in fome places, little, or none: in others, in fuch plenty as to exceed even the ordinary Terreftrial Matter, and of it felf to compofe whole Strata, without any confiderable Admixture of Sand, Clay, or other common Matter. Thus we fometimes fee whole Strat compiled of Metallick and Mineral Pyrita : others of Pebles, and of Flints, without the Interpofition of any other Matter : that finer Matter 
commonly found amongt thefe, and vulgarly called Sarsi, being really no other than very fmall Pebles; as may appear to any one who thall carefully examine and obferve it, efpecially with a good Microfcope. Thus like. wife we find Strats confifting almoft entirely of Common Salt: others of Ochre : and others of feveral Metalls and Minerals, Tin, Lead, Vitriol, Nitre, and Sulphur, promifcuouly, withour any confiderable Intermixture of coarfer Terreftrial Matter.

4. That the metallick and mineral Matter, which is now found in the perpendicular Intervalls of the Strata, was all of it originally, and at the time of the Deluge, lodged in the Bodies of thofe Strats : being interfperfed or fcattered in fingle Corpufcles, amongft the Sand, or other Matter, whereof the faid Strata mainly confift. That it was educed thence, and tranfmitted into thefe Intervalls, fince that time; the Intervalls themfelves not exifting till the Strata were formed, and the metallick and mine. ral Matter actually lodged in them; they being only Breaches of the Strata, and not made till the very conclufion 


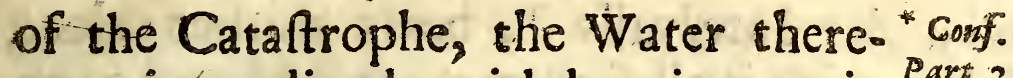
upon immediately withdrawing again ${ }_{\operatorname{Conn} .3 .2 .6 .}$ from off the Earth *. and $P$ art 3.

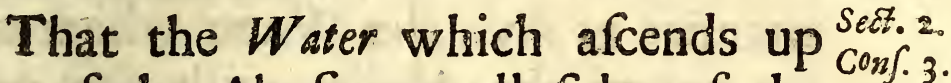
out of the Abyfs, on all fides of the $\begin{gathered}0 . P a r t \\ \text { Part }\end{gathered}$ Globe, rowards the Surface of the Conf. 3. Earth $\uparrow$, inceffantly pervading the 5 . Pores of the Sirata, I mean the Inter- + part $3^{\circ}$ itices of the Sand or other Matter Sect. $\pi$. whereof they confilt, detaches and $\operatorname{conf} .8$. bears along with it all fuch metallick, mineral, and other Corpufcles which lye loofe in its way, and are withal fo fmall as to be able to pafs thofe Interftices: forcing them along with it into the perpendicular Intervalls; to which it naturally directs its courfe, as finding there a ready Exit and Difcharge $\|$, being partly exhaled thence $\|$ Ibid.

up into the Atmofphere, and partly flowing forth upon the Surface of the Earth, and forming Springs and R:vers.

That the Water which falls upon the Surface of the Earth in Rain, bears alfo fome; though a leffer, fhare in this Action; this, foaking into the Strata which lye near the Surface, Atraining through the Pores of them, and advancing on towards their perpendicu- 
* Part 3. lar Intervalls *, bears thither along Sect. 1. with it all fuch moveable Matter as ocEonf. 4 . currs in thofe Pores, in much the fame manner as does the Water which arifes out of the Abyfs; with this only difference, that this paffes and pervades none but the fuperficial and uppermoft Strata, whereas the ot ber permeates alfo thofe which lye lower and deeper.

That the metallick and mineral Corpufcles, being thus conveyed into thefe Intervalls; and the Water there having more room and freer paffage than before, whilt it only penetrated the Pores of the Stone, it deferts the faid Corpnfcles, leaving them in thefe Intervalls; unlefs it flow forth with a very rapid and precipitate Motion; for then it hurries them out along with it, + Conf. till its Motion becomes more languid 13. infra. dons them $\downarrow$.

6. That by the Water, thus paffing through the Stone to its perpendicular Interyalls, was brought thither all the metallick and mineral Matter which is now ladged therein: as well that which lyes only in an indigefted and confufed u vid. Pag. Pile $\|$, in which manner the far great178. fupra. eft part of it is found, and particularly 


\section{Part IV. of the Eartb.}

the common Ores of Metalls, Iron, Tin, Lead, and the reft, as allo Spar, Alum, Vitriol, Sulphur, and other Minerals : as that which is difpoled and formed into fome obfervable $\mathrm{Fi}$ gure, fuch as the metallick and mineral Stalactite, the angulated or Cryftallized Metalls and Minerals ${ }^{*}$, and, ${ }_{178 \text {. fupra. }}^{{ }^{*} \text { ia. Pag. }}$ to be fhort, all others whatever.

That there is not, whatever fome 7 . Men may have fancied, any thing very ftrange or extraordinary in the Production of the faid formed Metalls and Minerals, which are found in thefe Intervalls: nor other plaftick Vertue concerned in thaping them into thofe Figures than meerly the Configurations of the Particles whereof they confift, and the fimple Motion of the Water to bring thofe Particles together. That particularly the common Stalactites, Lapis Stillatitius, or Dropftone, which confilts principally of Spar, and is frequently found, in form of an Icycle, hanging down from the tops and fides of Grotto's, and of the leffer perpendicular Intervalls, was formed by the Water which continually is palling through the Strata into thefe their Intervalls; this taking the 
Sparry Particles as they lay difperfedly mingled $w$ ith the Sand, or other Matter whereof thofe Strata confift, and bearing them on with it to the faid Intervalls; where iffuing leifurely out of the Strata, and having now free paffage, it deferts thefe Particles, falling down from the tops and fides of the Grotto's, to which the Particles affixing by little and little, incruift them over with a Sparry Cover, and alfo from thefe Stalactitie, from which the Water is continually falling and diftilling drop by drop; which gave occafion to that Miftake of thofe who fuppofe thefe Bodies to be only Water petrified, as they fpeak, or converted into thefe Sparry or Stony Iceycles, in the fame manner as it is by Froft congealed into the Icy ones which hang down from the Eaves of Houfes, from Pipes, or other conveyances of Water. That the Iron, and other metallick Stalactite : the Aluminous, and the Vitriolick Stalactite: the Saline ones, or thofe which confift of common Salt, and all others, are found fufpended in the fame manner, and their Matter conducted out of the Strata to their Piffures by the fame means.

That 
Part IV. of the Earth.

That the Iron-Rhombs, Tin-Grains, and other Ores of Metalls; which are found in thefe Intervalls naturally formed into Cubick, Pyramidal, or other Figures: as likewife the Minerals which are there fhot into the like Figures; fuch as the Mundick-Grains, cryftallized native Salt, Alum, Vitriol, and Sulphur: the Gemms alfo which are thus figured, e. g. Cryftal, the Pfeud-Adamantes; the Amethy ft, Emeraluld, and the reft: I fay thefe, afid all other natural metallick and mineral Cryftallizations, were effected by the Water, which firft brought the Particles whereof each confifts out from amongt the Matrer of the Strata, into thefe their Intervalls, in much the fame manner that the common, or artificial, Cty ftallizations of Alum, Vicriol, and the like, are now effected in the Water wherein they were before diffolved: and as are the Chymical Cry ftallizations of other Minerals and Metalls in their feveral Menfirua; whereof more in its place.

Thate the Corpufctes of Metalls and of Minerals being frisaller than thofe of Sand and of the other common Terreftrial Matter, and confequently the 
Pores of the Strata which confift main$1 y$, or at leaft contain in them a confi* confer. derable quantity of thefe *, being lefconfect. 3. fer and narrower than thofe of the Pag. 188. fupta.

Strata of Sand-ftone, and the like common and craffer Matter, the Water which afcends from beneath towards the Surface of the Earth is admitted into them, if at all, only in leffer quantity, paffes them flowly and difficultly, and therefore hath not Scope and Power fufficient to diflodge the Corpufcles, and bear them off with it into the perpendicular Intervalls, as it does in thofe Strata which confift chiefly of Stone, and the like groffer Matter, where the metallick and mineral Corpufcles lye thinner, and fo the Pores are more wide and open. That, for this reafon, in the Intervalls of thofe Strain which abound plentifully with Iron, 'Tin, Spar, common Salt, Alum, or the like, we ordinarily find a leffer quantity of there Metalls and Minerals refident, than we do in the Intervalls of fome other Strata which now fhew little, or perhaps nothing in the Bodies of them befides Sand and fuch like coarfer Matter; there being fo admirable a Contrivance in this Affair, that the 
Part IV. of the Earth.

the Water does not difurb and remove that metallick or mineral Matter which lves in the Strata in great plenty, and fo is there ready collected to the hand of Man : but only that which need's fuch an Agent to collect it: that which is fo fparingly and difperfedly intermix'd with the common Terreftrial Matter, as not to be difcoverabie by humane Induftry, or, if difcoverable, to diffuled and fcattered amongt the craffer and more unprofitable Matter, that 'twould never be puffible to $\mathrm{fe}$ parate and extract it: or, if 'twas, it would not defray the Chârge and Labour of the Extraction, and therefore muft needs have been all irretrievably loft, and ufelefs to Mankind, was it not here by this means collected and brought into one Mafs.

That therefore the Metalls and Minerals which are lodged in the perpendicular Intervalls of the Strata, do Atill grow, (to fpeak in the Mineralifts phrafe) or receive additional Encreafe from the Corpufcles which are yet daily born along with the Water into them : and have grown fo ever fince the time of the Deluge, in all fuch places where thofe Intervalls are not al.

$$
\text { o } 2 \text { ready }
$$


ready fo filled, that they cannot receive any more; or where the Stock of metallick and mineral Corpufcles, originally lodged in the Strata, is not quite exhaufted, and all borne thither already. That yet this Encreafe is not now any where very great; the Corpufcles, which were capable of being ftirred and removed, being, by the continual Paffage of the Water for fo many Ages, in moft places exhaufted, educed forth of the Strata, and tranfmitted into thefe their Fiffures.

11. That the metallick and mineral Matter which lyes in the Bodies of the Strata does not now grow : nor hath it ever received any Addition fince 'twas firft repofed in thofe Strata at the time of the Univerfal Deluge: but, on the contrary, hath been diminifhed and leffened by fo much as hath been conveyed into their perpendicular Intervalls, and as hath been brought forth upon the Surface of the Earth by " Vid. Conf. Springs, Rivers *, and Exhialations +" tVid. from the Abyfs, ever fince that time. Gonf. 14. That notwithitanding there have, and
infise do ftill, happen, Tranfitions and Removes of it, in the folid Strata, from one part- of the fame Stratum to another 


\section{Part IV. of the Barth.}

ther part of it, occafioned by the Motion of the Vapour towards the perpendicular Intervalls of the $\int e^{*}$ : and, "Part 3 . in the laser Strata, fuch as thofe of Corf. 8.

Sand, Clay, and the like, from the lower ones to thofe which lye above them, and even to the very Surface of the Earth, occafioned by the Motion of the Vapour directly towards the Surface, it pervading thefe loofer Strate diametrically $\psi_{\text {. }}$ But of this I have $+16 i d_{\text {o }}$ not room to enlarge more particularly in this place.

That the Bitumen which is found in $\mathbf{I} 2$. Lumps, or coagulated Maffes, in fome Springs; and which is, in others, found floating in form of an Oyl upon the Surface of the Water; when 'tis called by Naturalifts Naphtha, and Petroleum: the Salt wherewith the Saline, or SaltSprings, abound: the Vitriol, Alum, Nitre, Sulphur, Spar, and other Minerals, wherewith the Acidula, or Medicinal-Springs are faturated: I fay, all thefe Minerals were originally lodged in the Strata of Stone, Cole, Earth, or the like: that they were educed thence, and conveyed into thefe Springs, by the $\|$ conf. Water pervading thofe Strata in its paf- Sect. $\mathrm{r}$. fage from the Abyfs towards the faid conf. 8 . Springs $\|$.

$\mathrm{O}_{3}$ and Part 4 .

That $\operatorname{con}_{0} .5$. 
13. That when the Water of Rivers if fues out of the Apertures of them with more than ordinary Agitation and Rapidity, it ufually bears forth along with it fuch Particles of Spar, Argilla, or other loofe and moveable Matter as it met with in its Paffage through the Stone, Marble, or other folid Strata: that it fultains thefe Particles, and carries them on together with it till fuch time as its Motion begins to remit and be lefs rapid than it was at, and near its Source; when by degrees it lowers them, and lets them fall, depofing and affixing them upon any thing which occurrs in the way, as Stones, Shells, Sticks, or other like Bodies; efpecially thofe which lye in the Sinus's or Creeks of thofe Rivers where the Motion of the Water is more fluggilh and languid than in the Stream, or middle of the Chanel. That fome Rivers do thus bring forth Spar, and other mineral Matter in great quantity, fo as to cover and incruft the Stones, Sticks, and other Bodies lying therein, to a very confiderable Thicknefs. That fometimes the Water of StandingSprings does the fame : precipitating the mineral Matter which it brought 
forth of the Strata, upon the Stones at the bottoms and fides of the faid Springs: and affixing it upon Sticks, Straws, and other Bodies, and upon the Mofs, or other Plants which happen to grow therein, incrufting them over, in like manner as does the abovementioned Water of Rivers.

That when the Heat at, and upon, 14. the Surface of the Earth is great, it not onnly mounts up the Water fent from beneath, and, along with it, the lighter Terreftriāl Vegetative Matter *, but * Part $\mathbf{~}$.

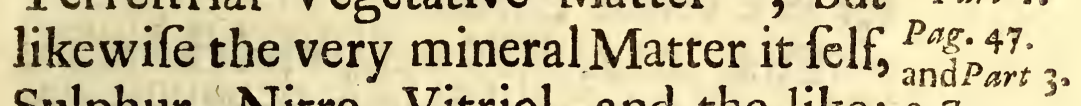
Sulphur, Nitre, Vitriol, and the like; setet. I. the Atoms, or fingle Corpufcles where- $\operatorname{conf} .8$. of being detach'd from their refpective Beds in the Earth, it bears quite to the Surface of it, and the light and more active forts of them up into the Atmofphere, (together with the Vapour, which, when condenfed, falls down again in Rain) in greater or leffer plenty, and to a greater or leffer height, anfwerably to the greater or leffer quantity or Intenfenefs of the Heat,

That wherever there happen to be any extraordinary Dicharges of the Subterranean Heat: either Vulcano's, or leffer Spiracles, fuch as thofe about

$$
\mathrm{O}_{4} \text { Naples, }
$$


Naples, Pozzuolo, and in other Parts of the World : Therme, or Hot-prings: or fiery Eructations, fuch as burft forth of the Earth during Earthquakes: I fay wherever there are fuch or the like Difcharges of this Subterranean Fire, there likewife is mineral Matter, more or lefs, hurried up along with it. That even the Heat of the Sun, and indeed any other, though but an accidental Heat, hath the fame Effect, and contributes to the raifing of mineral Matter out of the Earth.

That Aina, Vefurius, and the other Vulcano's difcharge forth, together with the Fire, not only metallick and mineral Matter in great quantity, but Sand likewife, and huge Stones, toffing them up fometimes to a very great height in the Air.

That the Heat, which arifes out of the leffer Spiracles, allo brings forth along with it mineral Matter, and particularly Nitre, and Sulphur ; fome of which it affixes to the tops and fides of the Grotto's as it paffes, which Grotto's are ufually fo hot as to ferve for natural Stoves, or Sweating. Vaults: fome it depofes near unto, and even upon, the Surface of the Earth; infomuch 


\section{Part IV. of tbe Eartb.}

much that in fome places the Flores Sulphuris are gathered in confiderable plenty near thefe Spiracles: fome it bears in Steams up into the Air, and this in fuch quantity too as to be manifeft to the Smell, efpecially the Sul. phur, that Mineral fo particularly affectirig this Senfe.

That the Heat which is continually paffing up towards the Therme, brings thither alpng with it Particles of Spar, Alum, Sulphur, Nitre, and other Minerals in fuch quantity, that thefe ordinarily as much exceed the common Acidule * in plenty of this mineral ${ }^{*}$ Vid. Matter as they do in Heat. That this Conf. I2. Heat, afcending out of the Therma, bears up with it not only Water, in form of Vapour, but likewife mineral Matter; fome whereof it affixes to the Sides and Arches of the Grotto's, where thefe Therma arife in fuch: or, if they be covered with Buildings, to the Walls and Roofs of thofe Buildings: to the Pipes thraugh which the Water is conveyed, or the like. That Sulphur is in fome places collected very plentifully adhering to the Stone of thefe Grotts, and Buildings: yea fometimes Spar, and other craffer Minerals, are thus 
mounted up, and affix to the Walls and Roofs, incruft them over, and, being ftop'd and reverberated thereby, form Stalactita, or Sparry Iceycles hanging down from the Arches of the Grotto's, from the Capitals of the Pillars, and Roofs of the Buildings. That where thefe Therma are not thus covered and vaulted over, fo that the mineral Matter is not ftop'd and hinder'd in its Afcent, a great part of it advances directly up into the AtmoIphere.

That the Heat which is difcharged out of the Earth at the time of Earth \| Part 3. quakes || brings forth Nitre, Sulphur, sect. I. and other mineral Matter along with Conf. 12 . it. That the Water alfo which is at pag. 139. or 141 . Expra.

the fame time fpued out*, through the Cracks or Chafmes opened by the Earthquake, and through the Apertures of Springs and Rivers, is turbid and ftinking, as being highly faturated with mineral Matter. That the Aciduld, or Medical Springs emit then likewife a greater quantity of their Minerals than ufual : and even the ordinary Springs, which were before clear, frefh, and limpid, become thick and rurbis, and are impregnated with Sul- 
phur and other Minerals as long as the Earthquake lafts. That thefe Minerals do not iffue out only at thefe larger Exits, but fteam forth likewife through the Pores of the Earth, occafioning thofe fulphureous and other offenfive Stenches which ufually attend Earthquakes, and are the Caufe of the $\mathrm{Fe}$ vers and other malignant Diftempers which commonly fucceed them: bringing on oftentimes great Mortalities, not only amongft Men, but even the very Bealts and Fifhes. That thefe mineral Eructations arife in fuch quantity up into the Atmolphere as to thicken, difcolour, and darken it fomętimes to a very great degree.

That any Heat whatfoever, even an accidental one, fuch as is that which proceeds from the Bodies of Animals, and from their Excrements, promotes the Afcent of mineral Matter, but more efpecially of that which is fubtile, light, and active, and is confequently moveable more eafily, and with a leffer Power. That by this means Nitre (wherever there happens to be any in the Earth underneath) is raifed in Stables, Pigeon-Houfes, and other like Receptacles of Animals : and in thofe places 
places where their Dung lyes heap'd up. That 'twas this which occafioned, in fome, an Opinion that Nitre proceeds forth of thofe Animals, and their Excrements; whereas it is found raifed up, and convened or collected indifferently and as well in Buildings where Animals rarely or never come, as in thofe they ordinarily frequent; not to mention that which is found fometimes in confiderable plenty. at great depths in the Earth: in the Water of springs, of Rivers, of Lakes, and, in fome Parts, even of the Sea it felf; whereof more largely hereafter. That, in fuch places where the Earth contains Nitre within it, though there be no fuch adventitious Heat, if that Heat which is almoft continually fteaming out of the Earth be but preferved, its Diffipation prevented, and the Cold kept off by fome Building or other like Coverture, this alone is ordinarily fufficient to raife up the Nitre, and bear it out at the Surface of the Earth, (unlefs its Egrefs be impeded by Pavements, or the like Obitructions) and mount it up into the Air, as far as thofe Buildings will permit. For, the Cielings and Walls ftopping it in its Afcent, 
Part IV.

of the Earth.

Afcent, it ufually affixes, unto them, and fettles there. And accordingly 'tis frequently found this affix'd to the Walls and Cielings of Ground-Roorins; Cellars, and Vaults; $;$ and this fonietimes in fuch quantities as tó form nitrofe Stalactite $\$$, hanging down fromi + Confor.

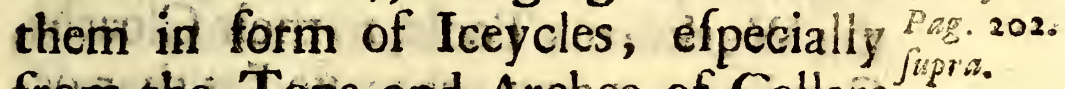
from the Tops and Arches of Cellars and Vauilts.

That the Heat of the Sun in the hotter Seafons being very intenfe, and penetrating the exteriour or fuperficial parts of the Earth, it thereby excites and firs tup thofe mineral Exbatacions, in fibterrancoous Caverns, in Mines, and in Cole-pits, which are commonily called Damps. That it is for this reafori that thefe feldom or never happen but in the Summer time; when, the hotter the Weather is, the greater and more frequent ate the Damps. That befides this of the Surn, they are alfo fometimes raifed by the Acceffion of other Heat, and particularly by the Fires which the Miners ufe in the Grooves, for breaking the Rocks, and for other Ends. That the Quantity of mineral Martter thus raifed is according as there is more or lefs of it in thofe Mines, efpeci- 
efpecially of Sulphur, Nitre, and the like fubtile and eafily moveable Minerals : and as the Heat is tbere more or lefs intenfe. That this mineral Matter being fuftained in the Air there, and floating about in the Mines, and Pits, it hits upon, and affixes it felf unto, the Workmens Tools, to their Cloaths, Candles, or any other Bodies that occurr. That where there is any confi. derable quantity of Sulphur in the Exhalation thus floating too and again, it takes fire at the Candles, burns with a blue Flame, and emits a ftrong fulphureous Smell. That thefe Damps - differ in their Effects according to the different Minerals that are the Caufe of them; ours in England being generally reducible to two kinds; whereof one is called the Suffocating, the other the Fulminating Damp. That the former of thefe extinguifheth the Candles, makes the Workmen faine, and vertiginous, and, when very great, fuffocates, and kills them. The Fulminating Damp will take fire at a Candle, or other Flame, and, upon its Accenfion, gives a Crack or Report like the Difcharge of a Gun, and makes likewife an Explofion fo forcible as fome- 


\section{Part IV. of the Eartb.}

fometimes to kill the Miners, break their Limbs, thake the Earth, and force Coles, Stones, and other Bodies, even though they be of very great Weight and Bulk, from the bottom of the Pit or Mine, up through the Shaft, difcharging them out at the Top or Mouth of it, fometimes ftriking off the Turn which ftands thereon, and mounting all up to a great height in the Air; this being fucceeded by a Smoak, which both in Smell, and all other refpects, refembles that of fired Gunpowder; and is, as may appear from thefe and other Phrenomena of it, nothing but an Exhalation of Nitre and Sulphur, which are the principal Ingredients of that Compofition we call Gunpowder. That as thefe Damps are caufed by Heat, fo they are remedied by withdrawing that Heat, and by conveying forth the mineral Steams; which the viners effect by Perflations with large Bellows: by letting down Tubes, and finking new Shafts; whereby they give free paflage and motion to the Air, which ventilates and cools the Mines, purges and frees them from thefe mineral Exhalasions. 
That at fuch time as the Sun's powerr is fo great as thus to penetrate the exteriour Parts of the Earth: to difturib thefe miniteral Patticles: atdd raife thetn from out the Strata whierein they lây, it does not owly fuftain them in the Air of Grotto's, Mithes; and other Catvertis under ground, but likewife bear's them out throutgh the Mouths of thofe $\mathrm{Ca}$ verns; and through the ordihary $C_{\text {Cácls }}$ and Pơes of the Earth, mounting them up, along with the watery Exhalati+ vid.Part ons, into the Atmolphere e efpecial3. Sect. sv ly Sulphur, Nitre, and the other more
cons. conf. 8. light and active Minerals; where they form Meteors; and are particularly the Caufe of Thuinder, and of Lightning. That, this mineral Matter requirining a confiderable degree of Hêtat to raîe it, the moft Northern Climes, and the Winter Seafons are, for that rềfon, fittle or not at all troubled with Thứnder; it feldom happening, in any great meafure, but in the hotter Montlis, and in the Southern Countries, as in Congo, Guinea, and other Parts of Africa, and in the Southern Parts of Affa and Americe; where 'tis, during the Sea\|Vid. Pag. fon of their great Rains \|, horribly loud 126.5uppra. and aftonifhing, and as much exceeds the 
Part IV. of the Earth.

the Thunder of thefe Northern Climes, as the Heat there exceeds that of thefe Climes. That the mineral Matter which is difcharged forth of Vulcano's, and other like Spiracles: and out of the Therme, afcends up into the Air, and contributes to the Formation of thefe Meteors. That likewife the Nitre and Sulphur, which are belch'd forth of the Earth at the time of Earthquakes (the Countries which are moft obnoxious to this Malady abounding, as I have already intimated + , with thefe $+v i d$. pag. two Minerals particularly;) in fuch ${ }^{141 .}$. fupra plenty as to thicken and darken the Air, conftitute there a kind of Aerial Gunpowder, and are the Caufe of that difmal and terrible Thunder and Lightning which commonly, if not always, attend Earthquakes; even when all was till then calm and clear, and not the leaft Sign or Prefage of any fuch thing before the Earthquake began.

That as the mineral Eruptions which happen during Earthquakes ${ }^{*}$ : and the ${ }^{*} V_{i d}$. pag. Steams and Damps of Mines $\|$ are detri- ${ }^{203}$. Jupra. pag. mental to Health, hurtful and injurious 206. juprs. to the Bodies of Men and other Animals, fo likewife are the Mineral Exbalations which are thus raifed by the 
Sun out of the Body of the Earth up into the Atmofphere : but more efpecially in thofe Parts of it where there are Arfenical, or other like noxious Minerals lodged underneath. That the fe mingling with, and being diffeminated in, the Air, and paffing together with it into the Lungs in Refpira. tion, are by them tranfmitted into the Body, where they infect the Mafs of Blood, create Perturbations and diforderly Motions therein, and lay the Foundation of Pefilential Fevers, and other malignant Diftempers. That 'tis for this reafon that the Southern Countries are more frequently molefted and incommoded by there Diftempers than the Northern are : and that they are more rife and ftirring in the hotter Months, in Fuly and Auguft, than in the colder, December, Fanniary, and the reft. That 'tis indeed true, that in September and Oztober, which are none of the hotteft Months, thefe Difeafes are oftentimes as epidemical as in the precedent and warmer Seafon: and do not abate and remit in proportion to the remiffion of the Sun's Heat in thofe Months; but this is purely accidental, and happens meerly becaufe the Heat 


\section{Part IV. of the Earth.}

within the Surface of the Earth is not liable to fo fudden Viciffitudes, or fo guickly fpent and difperfed, as is that which is upon it, and in the Air. This therefore, the Pores of the Earth remaining ftill as free, and open, as ever, continues to fend out the mineral Stesms as before, but in leffer and leffer quantity, anfwerably to the gradual Diminution of this Heat. Which Steams, though now fent up to the Surface of the Earth only in leffer plenty, may be much more offenfive and mifchievous than in the hotter Months when it came forth in far greater. For the Sun's power being in thofe Months alfo greater, it then ftraitways hurries thefe Steams up into the Atmorphere: whereas in the colder, its power being leffened, it cannot bear it up fo faft; fo that it ftays and ftagnates near the Surface of the Earth, fwimming and floating about in that Region of the Air wherein we breath; where it mult needs be much more pernicious than when born up to a greater height, and fo farther out of the way. And this is indeed much the Cafe of Foggs: particularly of thofe which we frequentiy obferve after Sun-fetting, even in our 
hotteft Months. Thefe being nothing but a Vapour, confifting of Water, and of fuch mineral Matter as this met with in its paffage, and could well bring up along with it. Which Vapour was fent up in greater quantity all the foregoing Day, than now in the Evening; but the Sun, then being above the Horizon, taking it at the Surface of the Earth, and rapidly mounting it up into the Atmofphere, it was not difcernible, as now it is; becaufe, the Sun being now gone off, the Vapour ftagnates at and near the Earth, and faturates the Air till 'tis fo thick as to be eafily vifible therein. And when at length the Heat there is fomewhat further fpent, which is ufually about the middle of the Night, it falls down again in a Dew, alighting upon Herbs and other Vegetables, which it cherifhes, cools, and refrefhes, after the fcorching Heat of the foregoing Day. But if it happens, as fometimes it does, that this Vapour bears up along with it any noxious mineral Steams, it then blafts Vegetables, efpecially thofe which are more young and tender: blights Corn and Fruits : and is fometimes injurious even to Men who chance to be then 


\section{PartIV: of the Earth.}

then abroad in the Fields. 'Tis alfo the Cafe of Water at the Surface of the Earth *; where the Springs and Rivers * conf. are very low, yea fome of them ceafe ${ }_{\text {Sect }}^{\text {Part }}$, to yield any Water at all, in the Sum-Conf. 8 . mer Months, becaufe the Sun's Power is then fo great as eafily and fpeedily to bear up into the Atmofphere, in fmall and invifible parcels, and in form of an extremely fine and thin Vapour, a very great part of the Water which is fent up out of the Abyfs: whereas in the Winter-time the Sun is withdrawn farther off, and its power leffened, fo that it cannot then buoy it up as before; for which reafon 'tis that fo much more of it then ftands at the Surface of the Earth, and ftagnates there. So likewife for Rain; we learn from Experiment that there commonly falls in England, in France, and fome other Countries, more Rain in Fune and Fuly, than in December and Fanuary; but it makes a much greater Shew upon the Earth in the e Months than in thofe, becaufe it lyes longer upon it ; the Sun now wanting power to exhale and bear it up fo quickly and plentifully as then it did. Tis alfo the $C_{\text {afe }}$ of the Halitus emitted forth of the Lisings of

$$
P_{3} \text { Men }
$$


214 The Natural Hifory Part IV.

Men and other Animals. In a Phyfiological Treatife, which I have by me, concerning the Structure and $V\left(\int\right)$ of the Parts of Animals, difcourfing of the Lungs, I thew that they are the grand Emunctory of the Body : that the main End of Repiration is continually to difcharge and expell an excrementitious, Fluid out of the Mars of Blood: and prove from feveral Experiments that there paffes out of the Body a greater. quantity of Fluid Matter this way, I mean upwards, and through the Lungs, than there does of Urine, by the Kidneys, downwards. Now the Fluid, which is thus fecreted, and expired forth along with the Air, goes off with it in infenfible parcels, in the Summer Seafon, when the ambient Air contains Heat enough to bear it quickly away, and fo difperfe it. But in the Winter, when the Heat without is lefs, it of tentimes becomes fo far condenfed as to be vifible, flowing out of the Mouth in form of a Fume, or craffer Vapour: and may, by proper Veffels, fet in a ftrong freezing Mixture, the better to condenfe this Vapour, be collefted in confiderable quaritity. But to return. That 'tis not without a very extracrdi- 


\section{Part IV. of the Earth.}

nary Providence that there fo conftantly happens, in the Month of September (the time when chiefly thefe mineral Steams ftagnate thus at and near the Surface of the Earth) a very nipping and fevere Seafon of Cold, far beyond what might, from the Sun's height and power, be then expected: beyond that of October and Noveriber. and fometimes equal to that of Finuary and the coldeft Months: as alfo that there then fo conitantly happens very bluftering and turbulent Winds; the Cold ferving to check and put a ftop to the Afcent of this mineral Matter: and the Wind to diffipate and convey away that which was before raifed out of the Earth; which, was it not thus carried off, would be infinitely more fatal and pernicious to Man and other Animals than now it is. But I muft be contented here to give only fhort Hints of thefe, as of other, Things : and to write but obfcurely and refervedly, untill I have opportunity to exprefs my Sentiments of them with greater Copioufnefs, Freedom, and Perfpicuity.

Thus much of the Scheme of my Defign in this Part have I run over:

$$
\mathrm{P}_{4} \text { and }
$$


and lead my Reader a long and tedious Jaunt in tracing out thefe metallick and mineral Bodies : in purfuing them through their feveral Mazes and $\mathrm{Re}$ treats: through the Earth, the Water, and the Air. And yet, long as it is, we are not got much further than the Borders of the Mineral Kingdom, and have done little more yet than fettled and adjufted Preliminaries; fo very ample is this Kingdom, fo various and manifold its Productions. For the foregoing Conclufions relate only to the Origin and Growth of thefe Bodies; the Natural Hiffory of each particular. Me tall and Mineral, with the Obfervations whereon that Hiltory is grounded, being ftill to come. But I muft be forced wholly to wave and fuperfede the Detail of thefe ; for I perceive, do what I can, this Abftraet will fwell much beyond the bounds which I at firft de figned.

This Fourth Part will be followed by feveral Treatifes, ferving to confirm, and to illufirate fome Paffages in it: whereof I thall at prefent only mention the four following.

1. Rules and Directions for the Difcovery of Metalls and Minerals latent in 


\section{Part IV. of the Earth.}

the Earth: with an Enquiry why thefe lye fometimes fo near the Surface, and did not, (becaufe of their greater Gravity) at the General Subfidence in the Deluge $\uparrow$, fall to a much greater depth $+P_{\text {art }} 2$. than we now find them: even to fuch $\operatorname{conf} .3 .3$.

a depth as to have lain quite out of cons. 3 . humane reach, and fo have been all buried, and irrecoverably loft.

2. An Examination of the Common Doctrine about the Generation of $M e=$ talls and Minerals : and particularly that of the Chymifts; with an Appendix, relating to the Tranfmutation of Metalls : detecting the Impoftures and Elufions of thofe who have pretended to it: and evincing the Impoffibility of it from the moft plain, fimple, and Phyfical Reafons : proving likewife that there are no fuch natural Gradations, and Converfions of one Metall and Mineral into another, in the Earth, as many have fancied. As alfo an Account of the Mineral fayces in the Earth, which fome Writers have imagined to be I know not what Seeds of Minerals, fhewing that they are, for the far greateft part, nothing but Water ftrongly impregnated with Mineral Matter, which it derives from 
\|corr.s.sce. the Strata as it paffes through them\|. fupra.

3. Relations, obtained from feveral Hands, concerning the State of Metalls and Minerals in Foreign Consetries: in divers Parts of Afa, Africa, and America, as well as in Hingary, Germany, Sweden, and other Parts of Europe : and particularly of thofe which are not found in England; fhewing that the Condition of thefe Bodies in thofe remoter Regions is exactly conformable to that of ours here: and that they were all put into this Condition by the + conf. very fanie means $\uparrow$. couf. I. $\quad$ 4. Ob/ervations concerning Englinh

Amber: and Relations from abroad, about the Amber of Prufsa and other diftant Places: with a Difcourfe founded upon them, proving that Amber is not a grammous or refinous Subftance drawn out of Trees by the Sun's Heat; and coagulated and hardened by fall: ing down into Rivers, or the Sea, as the Ancients generally believed: but is a Natural Foffal, as Pebles, Flints, $P$ y. rite, and the like, are: formed at the fame time, and by the fame means that they were: and all of it originally repofed in the Strata of Earth, Sand, Oo. together with them. That 


\section{Pare IV. of the Earth.}

it is indeed found in fome places lying upon the Shores of the Sea, and of $\mathrm{Ri}$ vers: but 'tis alfo found at Land, and dug up (fometimes at very great depths) in the Earth; and this as well in Places very remote from any Sea, or River, as in thofe which are nearer unto them. That 'tis digged out of even the higheft Mountains, and indeed all other Parts of the Earth contingently and indifferently, as the $\boldsymbol{P y}$ rite, Agates, Jafpers, Pebles, and the reft, are. That wherever 'tis found upon the Sea-Shores, there alfo is it as certainly found at Land, up in the neighbouring Country : and particularly in Pruffa, upon whofe Shores fo great a quantity of Amber is yearly collected,'tis dug up almoft all over the Country. That even that which now lyes loofe upon the Sea-Shores, was all of it originally lodged in the Earth : in the Strata of Sand, Marle, Clay, and the like, whereof the neighbouring Land, and the Cliffs adjacent to thofe Shores, do confift; and wherever 'tis fo found fcattered upon the Shores, there is it as conftantly found lodged in the Cliffs thereabouts. That when the Sea, at High-water, comes up unto, 
and bears hard upon, the faid Cliffs, and is agitated by Winds and Storms, it frequently beats down huge pieces of Earth from them ; which Earth, falling into the Water, is, by its continued Agitation and Motion diffolved, and borne by degrees down into the Sea, being loofe, and light, and fo eafily reduced into leffer Parcels, diffolved, and wah'd away: but the Pebles, Pyrite, Amber, or other like Nodules, which happened to be repofed in thofe Cliffs, amongtt the Earth fo beaten down, being hard, and not fo diffoluble, and likewife more bulky and ponderous, are left behind upon the Shores, being impeded, and fecured, by that their bulk and weight, from being born along with the Terreftrial Matter into the Sea. That therefore the Sea is no ways concerned in the Formation of thefe Bodies : no more in the Formation of Amber, than of the Pyrite, Flints, and other mineral Maffes that are found together with it : but only dillodges and difcovers them, bears away the Earth wherein they were buried, wafhes off the Soil and Sordes wherein they were involved and concealed, and thereby renders them more confpi- 


\section{Part IV. of the Eartb.}

confpicuous, apparent, and eafie to be found. That this is fo known and experienced amongft the People who are employed to gather the Amber, that they always run down to the Sea-fide after a Storm, for that purpofe ; and, if it hath been fo great as to beat down part of the Cliffs there, they affuredly find Amber, more or lefs, upon the Seas $\mathrm{kbb}$ and Retirement, and after every Retreat of the Sea for fome Tides after; the Sea not bearing down the Earth immediately and all at once, but wafhing it off by little and little, and fo difcovering the Amber by degrees, fome after one Tide, and fome after another. That particularly the Am. ber, Vitriolick Pyrite, and other like Bodies, that are found upon the Shores of Kent, EJJex, HampJbire, and elfewhere, all came firft from the bordering Cliffs, and were dillodged by this means; and are found in the Earth, as well as upon the Shores, whenever 'tis laid open, as in finking Wells, Pits, and the like. That not only the Sea, but Rivers and Rains alfo, are inftru. mental to the Detection of Amber; and other Folfils, by wafhing away the Earth and Dirt that before covered 
and concealed them. Thus the Gol. den Pyrite, or, as they are common: ly called, Gold-grains, Amethyftine Pebles, Amber, and other Stones of Worth, are uncovered by fuch Rivers as chance to run through the Grounds which contain thofe Bodies in them. Thus likewife Rains, by their wafhing the Earth down from off the - Part 5. Hills*, clear, and difclofe fuch Pyrite, conf. 2. Selenite, or other Bodies that happen to be lodged, near the Surface of the Earth, in thofe Hills: and 'tis by this means chiefly that the Grain-Gold, upon all the Golden Coaft (as'tis called) in Guinea, is difplayed; the Rains falling there in great Abundance, and with incredible Force, thereby the more powerfully beating off the Earth. This the Negrues, Natives of thofe Parts, know full well; and therefore do not expect to find much of it unlefs

* $v$ id. after the Seafon of their Rains $\|$; when Part 3. they never fail to find of it, no more
Sect. cons. 8. than the Amber-Gatherers fail of findP.ag. I26. ing that upon the Sea-Coafts after a Storm. And if thofe Perfons who are curious in collecting either Minerals, or the Shells, Teeth, or other Parts of Animal Bodies that have been buried in 


\section{Part IV. of the Eartb.}

the Earth, do but fearch the Hills after Rains, and the Sea-Shores after Storms, I dare undertake they will not lofe their Labour. But to return. That Amber is not only lodged in the Strata of Earth, and of Sand together with the other mineral Nodules, but is fometimes found actually growing unto, and combined into the fame Mass \| with the Pyrites, and \| vid. Confo. others of them. That it likewife fome. 2. fupra. times contains in it pieces of Straws, Flies, Shells, and other heterogeneous Bodies, in like manner as the Pyrite, Flints, and all other analogous Folfils do 1. That although Amber be molt $+I b i d$. commonly of a yellowifh Colour, and therefore not unlike fome kinds of Gums, yet there is found of it alfo of feveral other Colours, as black, white, brown, green, blue, and purple, to name no more. Yea the very fame Lump is frequently of different Colours. That thefe Coloursare all accidental, even the yellow it felf, and owing to the Intermixture of foreign Matter, which concreted into the fame Mafs with the proper Matter of this Stone, and with the heteroge-

neous 
neous Bodies which are included in

+ Ibid. it, at the time of its Coalition $t$. That this is the Cafe of Agates, of Cornelians, of Topazes, and many other coloured Stones; the Colours of feveral whereof, and even that of Amber it felf, may by a very eafie procefs, be in great meafure, if not wholly, extracted, and taken from them : and the Bodies of thefe Stones rendered almoft, if not quite, as pellucid as Cryftal, without fenfibly damaging the Texture of them. That even the moft obvious and ordinary Minerals are not free from this Contagion of adventitious Matter: Common Salt it felf, when found naturally cryftallized amongft other Minerals and Metalls, in the perpendicular Intervalls of the Strata of Stone, being, not only pellucid, as it naturally is when pure and fimple, but white alfo, and like the white cryftallized Spar: yellow, and nearly refembling the Topaz: blue, and not unlike the Saphire; and yet thefe fpecious Bodies, and Gemms as to outward thew, upon tryal, yield nothing but meer Salt, with an extremely 
Part IV. of the Earth:

tremely fmall Admixture of other Matter, which gave them their Tincture. Which may ferve for a further Inftance of the confufed ftate of Minerals in the Earth : and of the Uncertainty of their Colours and Figures $\uparrow$.

\author{
+ Conf. \\ Pag. 17\%。 \\ of Pag. \\ $\$ 74$.
}

\section{PART}




\section{PART V.}

Of the Alterations which the Terraqueous Globe bath undergone fince the time of the Deluge.

$T$ now remains that we take a view 1 of the Poftdiluvian State of this our Globe : that we examine how it hath ftood for this laft four thoufand years: that we enquire what Accidents have befallen it, and what Alterations it hath fuffered fince that wonderful Change it underwent at the Deluge.

There have been fome who have made a mighty Outcry about Changes and Alterations in the Terraqueous Globe. The Pretences and Pleas of each I confider in the firft Part of this Effay: Shewing that they are without any juft ground: and that there are no Signs or Footfteps, in all the whole Globe, of any fuch Alterations. And indeed 'tis well for the World that there 
there are not; for the Alterations which they have fancied are fuch as turn all the wrong way : fuch as are without ufe, and have no end at all, or, which is worfe than none, a bad one : and tend to the damage and detriment of the Earth and its Productions.

Notwithftanding, fome Alterations there are which it hath, and doth fill undergo. This is what we may pronounce with Certainty: and there want not Inftances enough fufficiently to vouch and atteft it. But thefe Alterations are of a quite different Strain: thefe are as amicable and benificent to the Earth and Terreftrial Bodies, as the other, were there really any fuch, would be pernicious and deftructive to both. I have already * given fome " Part 4.

Intimations of the Changes which hap. ${ }^{\circ}$ onf. 4 . pen in the interiour parts of the Earth, 1 mean the Tranfitions and Removes of Metalls and Minerals there: and Thewn of what ufe and advantage thofe Changes are to the World $\uparrow$. So that $+15 i d$.

I may now pafs freely on to confider corf.y. thofe which befall the exteriour, or Surface of it. And thefe are brought about filently and infenfibly; and, which is the conftant Method of Nature, with

$$
Q 2 \text { all }
$$


all imaginable Benignity and Gentlenefs. Here is none of the Hurry and Precipitation: none of the Bluftering and Violence: no more than any of the direful and ruinous Effects, which muft needs have attended thofe Suppofititious Changes. And as thefe Alterations are not great, fo neither are they numerous. I have made careful fearch on all hands, and canvafs'd the Matter with all poffible Diligence, and yet there are none that I can advance from my own Obfervations, but

1. That the upper or outermoft Stratum of Earth : that Stratum whereon Men and other Animals tread, and Vegetables grow, is in a perpetual Flux and Change; this being the common Fund and Promptuary that fupplies and fends forth Matter for the Formation of Bodies upon the face of the Earth. That all Animals, and particularly Mankind, as well as all Vegetables, which have had Being fince the Creation of the World, derived all the conftituent Matter of their Bodies, fucceffively, in all Ages, out of this Fund.

That the Matter which is thus drawn out of this Stratum for the Formation of thefe Bodies, is at length 


\section{Part V. of the Earth.}

laid down again in it, and reftored back unto it, upon the Diffolution of them; where it lies ready to be again affumed, and educed thence for the fitting forth of other like Bodies in a continual Succeffion.

That the conftituent Matter of any one Body being proper, and turning thus naturally, when again refunded into this Stratum, to the Conftitution of another like Body, there is a kind of Revolution or Circulation of it; fo that the Stock or Fund can never porfibly be exhaufted, nor the Flux and Alteration fenfible.

That as the Bodies which arife out of this Fund are various, differing very much, not only from one another, but the Members, Urgans, or Parts of each individual amongtt themfelves: fo likewife is the Matter of this Fund whereof they all confift. For though when confufedly blended and mingled, as it is whilft lying in this Stratum, it may put on a Face never fo uniform and alike, yet it is in reality very different, and confifts of feveral Ranks, Sets, or kinds of Corpufcles.

That all the Corpufcles that are of the fame Set, or Kind, agree in every

$$
\text { Q.3 thing, }
$$


thing, and are moft exactly like unto each other in all refpects: but thofe that are of diverfe kinds, differ from one another, as well in Matter or Subftance, in Specifick Gravity, in Hardnefs, in Flexibility, and feveral other ways, as in Bignefs and Figure. That from the various Compofures and Combinations of thefe Corpufcles together, liappen all the Varieties of the Bodies formed out of them : all their Differences in Colour and outward Appearance, in Tafte, in Smell, in Hardners, in fpecifick Gravity, and all other Regards; in much the fame manner as that vaft variety we fee of Words arifes from the various Order and Compofition of the twenty four Letters of the Alphabet. But of this Matter, and of the Proceis and Method of Nature in the Formation of Bodies out of it, I hall treat more at large in the Difcourse it felf: wherein I thall alfo confider the Opinions of Others, particularly the Ancients, and, amongt the reft, of Thales and $P_{y}$ thagoras, about the Elements or Principles of Natural Things: for I now haften to propofe the other Alterations that happen in the Terraqueous Globe. 


\section{Part V. of the Eartb:}

That Rocks, Mountains, and the 2. other Elevations of the Earth (efpecially thofe whofe Surfaces are yearly ftirr'd and difturbed by digging, plowing, or the like) fuffer a continual Decrement, and grow lower and lower; the fuperficial parts of them being by little and little wafh'd away by Rains, . and born down upon the fubjacent Plains and Valleys. That even the Stone it felf (whether naked and uncovered as in Rocks, or invefted with a Stratum of Earth as is that in our ordinary Hills ) is not, by its Solidity, priviledg'd and fecured againft them, but is diffolved by degrees, and wafh'd alfo down, in its turn, as well as the loofer Earth.

That the Matter which thus de- 3 . volves from the Hills down upon the lower Grounds, does not confiderably raise and augnsent them; a great part of it, viz. the vegetative and lighter Terreftrial Matter, being either mounted up into the Atmolphere by the afcend- ${ }^{*}$ Vid.part ing Vapour *, or carried along with ${ }_{3}^{*}$. Sect. I. the Rain-water into Rivers, and, by $\operatorname{conf} .8$. them, into the Sea + ; whence 'tis re- ${ }_{\text {Ponfer. }}$ turned back again to the Earth difper- $\sigma$ s seg. 47 . uti fedly by Rain $t$, and ferves for the ${ }_{128}$ Pag. 
232 The Natural Hiftary Part V.

Nutriment and Formation of the Plants which grow thereon : and the rest of it, being more crafs and ponderous, does not move far, but lodges in the Clefts, Craggs, and fides of the Rocks or Mountains, and at or near the Roots or Bottoms of them.

4. That the Stone of Rocks and Mountains being by degrees in this manner diffolved, and the Sand born off, the Shells, and other Marine Bodies which

"Part 2. were originally included therein *, are Conf 3. by that means let loofe, turned out, and expofed upon the Surface of the Earth. That tis for this reafon that thefe Marine Bodies are now moft commonly found upon Hills, and the higher Grounds; thofe few which are found below and at the bottoms of them, being for the moft part only fuch as have fallen down from above, and from the tops of them; thofe which were, at the time of the Deluge, re? pofed upon the Surface of the Earth, A. Vid. Pag. being moft of them perifh'd and gone |l: 65. 6. 66. and indeed thefe, which are yet exiftent, only accidentally preferved by their being at firit enclofed in the Strata of Stone, and fo fecured by it as long as it was it felf fecure, I mean, untill 


\section{Part V. of the Earth.}

untill it was thus diffolved, and fo could not any longer contribute any thing to their Prefervation.

That thefe Shells and other Bodies, being thus turned out of the Stone, and expofed loofe upon the Surface of the Earth, to the Injuries of Weather, and of the Plough, to be trod upon by Horfes and other Cattel, and to many other external Accidents, are, in tract of time, worn, fretted, and broken to piecés.

That the Shells being fo broken, ftruck off, and gone, the Stone included in them is thereby difclofed and fet at liberty; which Stone confifts of the Sand wherewith the Cavities of thofe Shells were filled when they were fuftained together with it in the Water at the Deluge $\|$, and which at length $\|$ Part 2. fubfided in them, and was lodged with conf.2.2. 3 . them in the Strata of Sand-ftone; the Sand contained within the Shell becoming folid and confiftent at the fame time that the ambient, or that of the Stratum without it, did $\uparrow$.

That therefore the Shells ferved as Conf. 4 . Plafms or Moulds to this Sand; which, when confolidated, and afterwards in tract of time by this means freed from 
its inveftient Shell, is of the fame thape and fize as is the Cavity of the Shell, of what kind foever tisat Shell happened to be. That this is the true Origin - Those which con of thofe Stones (confifting of Sand ${ }^{*}$ ) sal of Spar, which are called, by Authors, Cocblite. Flint,\&cc. I Conchite, Muite, Oftracite, Ctenite I, \&c. have confse and which are of conftant, regular, c.

Confi 2. lex, Concba, and the other Shells in Fecininiz. which they were moulded, and from which, by reafon of their fo near refemblance of the infides of them, they borrow their feveral Denominations.

6. That thefe formed Stones being by this means defpoiled of their Shells, and expofed naked, upon the Surface of the ground, to the Injuries before recited, do alfo themfelves in time decay, wear, and moulder away, and are frequently found defaced and broken to pieces: in like manner as the Strata of Stone wherein they were originally lodged firtt did: and afterwards the Shells wherein thefe Stones were enclofed and formed.

This Deterration, as 'tis called, or Devolution of Earth and Sand from the Mountains and higher grounds, is not in equal quantity and alike in all places, 


\section{Pare V. of the Earth.}

places, but varies according to the different beight of thofe Mountains, and to the extent of the Plane at top of them: to the different confiftence and durablenefs of the Strata whereof they confift: and according as they are more or lefs difturbed by Shomers + , + which Ploughing, or other Acsidents. Nay are much this Deterration varies in different parts lent in of even the fame Mountain; thofe fome Couno which lye nearer to the Brink or Mar ${ }_{\text {in }}^{\text {tries }}$ others. gin of it fuffering a quicker and greater Vid. Part Decrement than thofe which are more 3. Conf. 8 . remote therefrom, and towards the middle of it. But though this Devolution be thus different, "tis not any where, even where greateft, very confiderable; and therefore does not make any great Alteration in the Face of the Earth. This I have learn'd from $\mathrm{Ob}$ fervations purpofely made in feveral Parts of England; and when I hall, in the larger Work, propofe the Standard whereby I give Judgment of it, any one may prefently and eafily inform himfelf of the quantity and meafure of it, either here, or in any other part of the World.

There are indeed fome other $\mathrm{Ca}_{\mathrm{J} u \text { - }}$ alties that the Globe is obnoxious unto; fuch 
fuch as Earthquakes, and the burning Mountains, or Vulcanoes. But of thefe, I thank God, and the good Conftitution of this happy Inland, I have not had any opportunity of Obfervation. Yet fomething I have to offer concerning thefe, and the Caufes of them, from the Obfervations of others. Not that the Thing is fo very material, or that they make fuch havock of, and Alterations in, the Globe as fome Men fancy. We have affurance from $\mathrm{Hi}$ ftory, that Etna and Vefuvius have fent forth Flames, by fits, for this two or three thoufand years, and no doubt but they have done fo much longer; and yet we fee both Sicily and Campania, the Countries wherein thofe two Mountains ftand, are ftill where they were : nay the very Mountains themfelves are yet in Being, and have not fuffered any confiderable Diminution or Confumption, but are at this day the two higheft Mountains in thofe Countries. What they have really fuffered: by what means both thefe, and Earthquakes, are occafioned: and what are their Effects upon the Globe, thall be fully and carefully confidered in due place; from which Confidera. 


\section{Part V. of the Earth.}

tions it will appear, that even the e have their ufes: and that, although they do make fome leffer Alterations in. fome few Parts of the Earth, and fometimes moleft and incommode the Inhabitants of thofe Parts, yet the Agent, whereby both the one and the other is effected, is of that indifpenfible Neceffity and V/e both to the Earth it felf, to Mankind, and to all other the Productions of it, that they could not fubfilt without it. I have already given fome brief Intimations that $W$ inds and Hurricanes at Land *, Tempefts and "Part 4. Storms at Sea $\uparrow$, (things that have always been look'd upon with as evil an pag. 2150 ways been look'd upon with as evil an $+P_{\text {art }} \mathbf{I}$. eye as Earthquakes, and pointed at as ${ }^{\text {Pag. }}$. 99. only difaftrous and mifchievous to the World) are yet not without a very neceffary and excellent Ufe: the fame have I alfo done concerning Vulcano's $\|;\|$ Part 3 . but I muft not $d$ well upon thefe things Sect. $r$. too long, wherefore I thall only now Conf. 13. difpatch what is further neceffary to be hinted here about this Decrement of Mountains, and then conclude this Part.

And this, as it does not make any great Alteration, fo neither doth that, which it really does make, any ways endamage. 
endamage or diforder the Globe: nor is it any the leaft Detriment or Difadvantage to the Productions of it, to Vegetables, to Animals, and particularly to Mankind: nor does it thwart and interfere with the grand Defign of Providence, viz. the Confervation of the Globe, and the Propagation of Bodies upon it, for the ufe of Man. So far from this, that it is very highly beneficial and ferviceable to both; which will further appear if we confider,

That in the firft Ages after the Deluge, when the number of Mankind, of Quadrupeds, and of the other Animals was but fmall, the Vallies and Plains were more than fufficient for their Habitation and Ufe. And, by fuch time as that Stock of them was enlarged, that they were further foread and multiplied, and thereby the Earth fo far peopled and replenifh'd that the Hills and higher Grounds began to be needed; thofe Rocks and Mountains which in the firft Ages were high, fteep, and craggy, and confequently then inconvenient and unfit for Habitation, were by this continual Deterration brought to a lower pitch, rendered 


\section{Part V. of the Eartb.}

dered more plain and even, and reduced nearer to the ordinary Level of the Earth; by which means they were made habitable by fuch time as there was occafion for them, fit for Tillage, for the Production of Vegetables, of Corn, and other Neceflaries, for the ufe of their Inhabitants.

That although the principal Intention in the Precipitation of the Vegetative Terreftrial Matter ${ }^{*}$, at the Deluge, ${ }^{*}$ Part 2. and the burying it in the Strata ${ }^{\text {pag. } 89,90 \%}$ underneath amongt the Sand, and other mineral Matter, was to retrench and abridge the Luscury and Superabundance of the Productions of the Earth, which had been fo ingratefully and fcandaloufly abufed by its former Inliabitants, and to caufe it to deal them forth for the future more frugally and fparingly; yet there was a ftill further Defign in that Precipitation: and the Matter fo buried was to be brought up upon the Stage once more; being only referved in ftore for the benefit of Pofterity, and to be, by this Deterration, fetch'd out to light again to fupply the Wants of the latter Ages of the World. For had thefe Strata of Stone, and other mi- 
neral Matter, which lay then underneath, been altogether deftitute of this Vegetative Intermixture, and had not contained fome, though a fmaller and more parfimonious Supply of it in them: had there not been alfo vaft numbers of Shells, Teeth, Bones, and the like, lodged in them, which are, $\| V_{i d}$. when rotted and diffolved, $\|$ a proper consect. 5. and natural Manure to the Earth, as
fupra.

all Parts whatfoever of Animals, as well as Vegetables, are ; they confift. ing of fuch Matter as the upper and Vegetative Stratum it felf contains, and therefore fuch as is fit for the Conftitu-

* confer. tion of Plants and of Animals * I fay, fonfr. r. had it not been for this, when the upper and Vegetative Stratum was once wafh'd off, and born down by Rains, the Hills would have become all perfectly barren, the Strata below yielding only meer fteril and mineral Matter, fuch as was wholly inept and improper for the Formation of Vegetables. Nay, the Inconvenience would not have ftop'd there, but have fpread it felf much further. For, the Vegetative Stratum being carried off, and the Devolution ftill continuing, the Matter of the lower or mineral Strata being 
Párt V.

being likewife by degrees borne down fucceffively to the Roots and Bottoms of the Hills, and upon the neighbouring parts of the Valleys and Plains, it would, as far as it reach'd, have cover'd and buried the upper and vegetative Stratum that was expanded over thofe Valleys and Plains, and render'd as much of them as it fo covered alfo fruftrate, fteril, and unfruitful. So that by this means, in the latter Ages of the World, when the Earth fhould be fully peopled, and all Quarters and Corners of it ftock'd with Inhabitants, and when confequently there would be the greateft need and occafion for its Productions every where, for fupply of the Neceffities of thefe its nus merous Inhabitants, there would have been then much lefs than ever, a great part of the Earth being rendered entirely barren; fo that they might have e'en ftarved, had it not been for this Providential Referve: this Hoord, if I may fo fay, that was ftowed in the Strata underneath, and now feafonably difclofed and brought forth.

R

PAR T 


\section{PART VI.}

Concerning the State of the Earth, and the Productions of it, before the Deluge.

7 HE Thread of this Difcourfe draws now near to an End; and I have reafon to fear that, by this time, the Reader, as well as my felf, thinks it high time that it were quite Ipun out.' For which reafon I thall not any longer prefume upon his Patience farther than needs I muft.

In the five foregoing Parts of this Effay I lay down what I have to propofe relating to the Condition of the Earth during the time of the Deluge, and ever fince that time. And here I am to make a Stand : to look a great way back: and make fome Reflections upon the Pofture of Things before the Deluge. 


\section{Part VI. of the Earth.}

The Method I take may perhaps be cenfured by fome as prepofterous, becaufe I thus treat laft of the Antedilu. vian Earth, which was firft in order of Nature. But they will, I hope; let fall that Cenfure, when they are acquainted that 'tis a thing of Conftraint, and not of Choice : and that 'twas for want of Footing, and good ground to go upon, that I did not take that Earth under Confideration fooner. The truth is, there was no way for me to come to any competent Knowledge of it, or to give any fure Judgment concerning it, but meerly by Induction: and by Contemplation of the Shells, Bones, and other Remains of it, which are ftill in being. Now before I could inferr any thing from the $e_{\text {, }}$ it lay upon me to make out that they all belonged to the Earth, and were the genuine Products of it: to thew likewife how they became buried and difpoled in the manner we now find them: and by what means they were preferved till now. And that is what I have been hitherto about; fo that this is indeed but the proper place for this Difquifition concerning the Antediluvian Earth : and

$R$ 2. it 
244 The Natural Hiftory Part VI. it could not well have been brought $\therefore$ in before.

Had there not been ftill remaining a great many Animal and Vegetable Bodies that were the legitimate Offfprings of that Earth, 'twould have been an extravagant and impracticable Undertaking to have gone about to have determined any thing concerning it ; and the more fo becaufe the Earth

"Part 2. it felf was diffolved and deftroyed*. corf. 2. But I prove that there are fuch Remains of it, enclofed in great plenty in the Marble, Stone, and the other compacter Strata of the prefent Earth; whereby they have been preferved, through fo many Ages, quite down to our Times: and are like to endure, many of them, much longer; even as long as the Strata themfelves continue in the Condition they now are; and fo will be a fure and lafting Monument and Witners of the Truth of that extraordinary Accident (the Deftruction of the Earth and of Mankind by the Deluge ) to Pofterity, quite down to the End of the World.

Now becaufe the Obfervations which I make ufe of in the former Parts of this Work give an Account of 


\section{Part VI. of the Earth.}

the faid Productions thus preferved, I

proceed upon thofe Obfervations, as hitherto, and, by Inferences which eafily, clearly, and naturally flow from them, thew what was the Condition and State of that Earth, and wherein it differ'd from this we now inhabit. And in regard that, from a Theory which, how much foever it may relifh of Wit and Invention, hath no real Foundation either in Nature or Hiftory, the Author fo often mentioned already hath fet forth an imaginary and fictitious Earth: whofe Pofture to the Sun he fuppofes to have been much different from that which the Earth at prefent obtains, and fuch that there could be no Alteration of Heat and Cold, Summer and Winter, as now there is, but a conftant Uniformity of Weather and Equality of Seafons $t:+$ Tbeory of An Earth without any Sea : without the Earth, Mountains, or other Inequalities $\|:_{l}^{l .1 . c .6 .0}$ and without either Metalls or Mine- $\| L$. x.c.s. rals *: in few words, one perfectly un- ${ }^{*}$ ibid. like what the Antediluvian Earth was l. 2.c.6. in truth and reality : and perfectly unlike that which Moles hath reprefented; I thall therefore interpofe fome Confectaries which would have R 3 been 
been otherwife needlefs and fuperflu-

- ous: which are directly levelled againft thefe Miftakes: and evince that whereever he hath receded from the Mofaick Account of that Earth, he hath at the fame time alfo receded from Nature, and Matter of Fact ; and this purely from the aforefaid Obfervations; from which I thall prove,

That the Face of the Earth, before the Deluge, was not fmooth, eaven, and uniform : but unequal, and diftinguifh'd with Mountains, Valleys, and Plains: as alfo with Sea, Lakes, and Rivers.

2. That the Quantity of $W$ ater upon the Surface of the Globe was nearly the fame as now : the Ocean of the fame Extent, and poffeft an equal thare of the Globe ; intermixing with the Land fo as to checquer it into Earth and Water, and to make much the fame Diverfities of Sea and Land that we behold at prefent.

3. That the Water of the Sea was faturated with Salt, in like manner as now it is: that it was agitated with Tides, or a Flux and Reflux: with Storms, and other Commotions.

4. That the Sea was very abundantly replenißged soith Fijh of all kinds: as 


\section{Part VI. of the Earth.}

well of the cartilaginous and fquammofe, as of the teftaceous and cruftaceous kinds: and that the Lakes and Rivers were as plentifully furnifh'd with Lake and River-Finh of all forts.

That the Earth was very exuberant5. ly befet with Trees, Shrubs, and Herbs: and ftock'd with Animals of all forts, Quadrupeds, Infects, and Foosls: and this on all fides, and in all parts of it, quite round the Globe.

That the Animal and Vegetable 6. Productions of the Antediluvian Earth did not in any wife differ from thofe of the prefent Earth. That there were then the very Same kinds of Animals and Vegetables, and the fame fubordinate Species under each kind that now there is. That they were of the fame fature and fize, as well as of the lame Bape: their Parts of the Same Fabrick, Texture, Conftitution, and Colour, as are thofe of the Animals and Vegetables at this day in being.

That there were both Metalls and Minerals in the Antediluvian Earth.

That the Terraqueous Globe had 8. the Jame Site and Pofition in refpect of the Sun that it now hath. That its Axis was not parallel to that of the

$$
\text { R } 4 \text { Eclip- }
$$


Ecliptick, but inclined in like manner as it is at prefent: and that there were the fame Succeffions of Heat and Cold, Wet and Dry : the fame Viciffitudes of Seafons, Spring, Summer, Autumn and Winter, that now there is.

It hath been already noted, that thefe Propofitions are founded on Obfervations made upon the Animal and Vegetable Remains of the Antediluvian Earth. From thofe Remains we may judge what fort of Earth that was: and fee that it was not much different from " Conf. this we now inhabit *. Now though Pag. 84. 'tis not to be expected that I bere forsog. mally lay down thofe Obfervations, that being not the Bufinefs of this Tract, yet untill I have Opportunity both of doing fo, and of fhewing in what manner the foregoing Propolitions flow from them, it may be very convenient that I give fome hort Directions how the Reader, for his prefent Satisfaction, may, of himfelf, and without my Affifiance, make out the principal Articles of thefe Propofitions from the Obfervations already delivered in the feveral Parts of this Difcourfe, and from one or two more that I thall add upon this Occafion. And that he may 


\section{Part VI. of the Earth.}

at one View difcover how confonant the Account which Moles hath left us of the Primitive Earth, is to this which we have from Nature, and how much the late Theory of the Earth differs from both, I will fet down that Writer's Senfe of the Matter under each Head as we pafs along.

To begin therefore with the Sea; That there was one before the Deluge, there needs not, I think, any other Proof than the Productions of it yet in being: the Shells, the Teeth, and Bones of Sea-Fihhes \|. And for Mofes, \|Conf. he is not at all averfe hereto; but as Part 2. exprefly afferts that there was then a Sea, as the Theory does, that there was none. Take it in his own words. + And God Said, Let the Waters under + Gen. $\mathrm{r}$. the Heaven be gathered together unto one 9,10 . place, and let the Dry-land appear : and it was fo. And God called the Dry-land Earth, and the gathering together of the Waters called be SEAS: and God faw that it was good. And though the Theorift flatly denies that there was then any fuch thing, yet he does not go about to difpute the Tranlation of this Paffage, but readily owns* ${ }^{*}$ that $M o *^{*}$ L. 1. c. . . fes hath here ufed a word that was com- 
mon and known to fignifie the Sea. Accor. ding to bim therefore, we fee the Sea was formed at the beginning of the World, and after its Formation approved of as good: that is, very neceffary and ferviceable to the Ends of Providence in the Kingdom of Nature ; and this indeed it is to many ways, that it mult needs be granted that that would have been a very wild World had it been without any Sea. The fepara. ting of the Sea and Land, and determining the fet Bounds of each, is here tVerf. $13 .+$ reckoned part of the Work of the third Day: as the ftocking of the Sea \|Verf.2r, with Whales and other Finhes, is $\|$ of 22. the fifth. And God created great Whales, \&c. and bleffed them, faying, be fruitful and multiply, and fill the Waters in the $S E A S$. And when on the fixth Day the finifhing Hand was fet to the Work, and Man created, God gives him Do* Verf. 28. minion over the Fifh of the $S E A$ *. 'Twould have been but a feanty and narrow Dominion, and Adam a very mean Prince, had there then been neither any Fifh exiftent nor Sea to contain them. Nay, this had been little better than a downright lllufion and abufing of him: and what is more, that 


\section{Part VI. of the Earth.}

that World had been fo far from excelling vars in the Abundance of its Productions, which is what the Theorift contends for on another Occafion, that twould have fallen far fhort of it : have wanted a very noble and large thare of the Creation which we enjoy : been deprived of a moft excellent and wholfome Fare, and very many delicious Difhes that we have the ufe and benefit of. But the Cafe was really much otherwife: and we have as good proof as could be wilh'd that there were not any of all thefe wanting. The things many of them yet extant fpeak aloud for themfelves: and are back'd with an early and general Tradition. For Mofes is fo far from being fingular in thus relating that the Sea is of as old a Date and Standing as the Earth it felf is, that he hath all, even the firft and remoteft Antiquity of his fide; the Gentil Account of the Creation making the Ocean to arife out of the Chaos almoft as foon as any thing befides. But we have in ftore a yet further Teftimony that will be granted to be beyond all Exception. 'Tis from the mouth of God himfelf, being part of the Law promulgated by him in a moft

folemn 
folemn and extraordinary manner. Exod. 20. II. In fix days the Lord made Heaven and Earth, the SE $A$, and all that in them is. 'Tis very hard to think the Theorift fhould not know this : and as hard that, knowing it, he fhould fo openly diffent from it.

Then for the Dimenfions of the Sea; that it was as large, and of as great extent as now it is, may be inferr'd from the vaft Multitudes of thofe Marine Bodies which are ftill found in all Parts t conf. of the known World t. Had thefe Pag. 6. been found in only one or two places: c Part 2. or did we meet with but fome few Species of them, and fuch as are the Products of one Climate or Country, it might have been fufpected that the Sea was then, what the $C_{a}$ pian is, only a great Pond or Lake, and confined to one part of the Globe. But feeing they are dug up at Land almoft every where, and in at leaft as great variety and plenty as they are obferved at Sea : fince likewife the foffil Shells are many of them of the fame kinds with thofe that now appear upon the neighbouring Shores, and the reft fuch as may well be prefumed to be living at the bottom, or in the interiour and deeper 


\section{Part VI. of the Earth.}

Parts of the adjacent Seas $\uparrow$, but never t Conf. any that are peculiar to remoter Seas ${ }_{\text {fupra. }}^{\text {Pag. }}$. or to the Shores of diftant Countries, we may reafonably conclude, not only that the Sea was of the fame bignels and capacity before the Deluge, but that it was of much the fame form alfo, and interwoven with the Earth in like manner as at this time: that there was Sea in or near the very Same places or Parts of the Globe : that each Sea had its peculiar Shells, and thofe of the fame $K$ inds that now it hath: that there was the Same diverfaty of Climates, here warmer and more agreeable to the Southern Shells, there colder and better fuited to the Northern ones: the fame variation of Soils, this Tract affording fuch a Terreftrial Matter as is proper for the Formation and Nourifhment of one fort of Shell-fifh, that of another: in few words, much the fame Appearance of Nature, and Face of Things that we behold in the prefent Earth. But of this more by and by.

That the Water of the Sea was Jalt, as now it is, may be made out likewife from thofe Shells and other the Productions of it ; they being of the fame Conftitution, and confifting of 
the fame fort of Matter that do the Shells at this day found upon our "vid. pag. Shores *. Now the Salt wherewith 22. 23. the Sea-water is faturated, is part of supra. the Food of the Shell-filh refiding therein, and a main Ingredient in the Make of their Bodies; they living up. on this, and upon the Mud and other Earthy Matter there.

And that the Sea Ebbed and Flowed before the Deluge, may be inferr'd, not fo moch from the Neceffity of that Motion, and the many and great Ufes + conf. of it in the Natural World + , as from pag. 48. certain Effects that it had upon the Shells, and other like Bodies yet pre. ferved. 'Tis known that the Sea, by this Accefs and Recefs, fhuffling the empty. Shells, or whatever elfe lies expoled upon the Shores, and bearing them along with it backward and forward upon the Sand there, frets and wears them away by little and little, in tract of time reducing thofe that are concave and gibbofe to a flat, and at length grinding them away almoft to nothing. And there are, not uncommonly, found Shells fo worn enclofed, amongft others, in Stone.

As the Sea-Thells afford us a fure Argument: 


\section{Part VI. of the Eartb.}

gument of a Sea, fo do the River-ones of Rivers in the Antediluvian Earth. And if there were Rivers, there muft needs alfo have been Mountains; for they will not flow unlefs upon a Declivity, and their Sources be raifed above the Earth's ordinary Surface, fo that they may run upon a Defcent $\|$; the Swiftness of their Current, and the Quantity of Water refunded by them, being proportioned generally to the beight of their Sources, and the Bignefs of the Mountains out of which they arife. Mountains being proved, nothing need be faid concerning Valleys; they neceffarily following from that Proof, as being nothing but the Intervalls betwixt the Mountains. But let us fee what Mofes hath on this Subjeet *. And the $W_{a-}{ }^{*}$ Gen. vii. ters (he is treating of the Deluge) ${ }^{19 .}$. I.

II. Part 3. Sęt. I. Pag. 153. \& 154. The Theorift, I know, flippofes both the Antediluvisn and the prefent Earth to be of an Oval Figure, and protended towards the Poles, as thinking that fuch a Figure would afford him a Plane fo much inclined torsards the Equator, that the Rivers might flow upon it though there. were no Mountains. But 'tis plain they could not. Nor are there any the leaft Ground's to bse lieve that the firft Earth wous of that Figure. If be had had any thing that had look'd like a Proof of $i$, he had done sell to bave produced it. But 'tis manifejt though we imagine the Earth formed that way be proposes, it roould not bave fallen into any fuch Figure. And for the preSent Earth, 'tis of a Figure as different from that which be affigns as it spell could be ; it being a Spheroides Prolatus, as apm pears from the late Difcoveries concerning it. 
prevailed exceedingly upon the Earth; and all the HIGH HILLS that were under the whole Heaven were covered. Fifteen Cubits upwards did the Watcrs prevail; and the MOUNT AINS were cavered. And all fle $\beta$ dyed:.-- all in whofe Noftrils was the breath of Life. The Theorift averrs, that there were no Mountains in the firft Earth. I am not willing to fuppofe that he charges a Fallhood or Miftake upon the Paffage, but rather that he would have this to be underftood of thofe Mountains which were raifed afterwards. Which yet cannot be ; for the Hiftorian here plainly makes thefe Mountains the Standards and Meafures of the Rife of the Water; which they could never have been had they not been ftanding when it did fo rife and overpour the Earth. His Intention in the whole is to acquaint us that all Land-Creatures whatever,bothMen, Quadrupeds,Birds, and Infects, perifh'd and were deftroyed by the Water, Noab only excepted, and they that were with him in the Ark. And at the fame time, to let us fee the Truth and Probability of the Thing : to convince us that there was no way for any to efcape, and particularly 


\section{Part VI. of the Earth:}

ticularly that none could fave themfelves by climbing up to the tops of the Mountains that then were, he affures us that they, even the higheft of them, were all covered and buried under Water. Now to fay that there were then no Mountains : and that this is meant of Mountains that were not formed till afterwards, makes it not intelligible, and indeed hardly common Senfe.

The extreme Fertility of both Sea and Land before the Deluge, appears fufficiently from the vaft and almolt incredible Numbers of their Productions yet extant *; not to infift upon * Vid. thofe which are long ago rotted and gone Nor need we much wonder ${ }^{+}$Conf. gone t. Nor need we much wonder Pag. 32. at this their abundant Fruitfulne $s$, when 66.77 .00 we know from what Source it pro- Part 3. ceeded; which our Hiftorian hath corrf. ir. opened to us in very fignificant words $\|$.$\| Gen. i.20.$ And God Jaid, let the Waters bring forth $\circlearrowleft$ seq. abundantly the moving Creature that bath life, \&c. --. And God bleffed them, Saying, be fruitful and multiply, and fill the Waters in the Seas: and let Fowl multiply in the Earth, \&c. Here was we fee a Bleffing, handed out with the firft Pairs of Animals at the moment of 
their Creation, very liberal and extenfive; and it had effect with a Witnefs. A Man that does but behold the mighty Sholes of Shells, to take them for an Inftance, that are ftill remaining, and that lye bedded and cumulated in many places heap upon heap, amongft the ordinary Matter of the Earth, will fcarcely be able to believe his Eyes, or conceive which way thefe could ever live or fubfift one by another. But yet fubfift they did: and, as they themfelves teftifie, well too; an Argument that that Earth did not deal out their Nourifhment with an over-fparing or illiberal Hand.

That thefe Productions of the Original Earth, differ not from thofe of the Prefent, either in Figure, in Magnitude, in Texture, or any other refpect, is eafily learn'd by comparing of them. The exact Agreement betwixt the $M_{a-}$ "Pag. 22, rine Bodies. I have fhewn already *: 23.COanf,
Gen, in Ir,

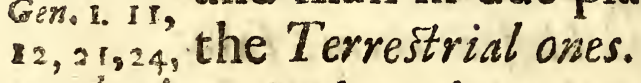
25. 20 vi. And as there were fuch great Numbers of Animals and Vegetables in the Primitive Earth, fo that there were alfo Metal's and Minerals, and thefe in no lefs plenty than in ours, is very. clear 


\section{Part VI. of the Earth.}

clear from what hath been delivered in the Fourth Part of this Eflay, which need not be repeated here. Nor is Mo es defective in this Point + And $+G$ er. Zillah, She alfo bare Tubal-Cain, in In-22.

ftructer of every Artificer in Brafs and Iron. The Theorift, quite contrary, fays, As for Subterraneous Things, Metalls and Minerals, I believe they bad none in the firf Earth; and the happier they; no Gold, nor Silver, nor coarfer Metalls. Amongft thefe coarfer Metalis are Copper, or Brafs, and Iron. Now if there were none of thefe, 'tis a great Myftery to me, I confefs, how 1 ubalCain, who certainly died either before or at the Deluge $\|$, could ever havell confer. taught the Workmanfhip and Ufe of Gen. vii. them. And yet if this Theory be true, ${ }_{2} P_{c e t}$. iit. there neither was nor could be any ${ }^{20}$. within their reach, or that they could ever polfibly come at. For the truth of the Theory I am in no wife concerned: the Compofer of it mutt look to that; but that there were really both Metalls and Minerals before the Deluge, is moft certain. For befides the Teltimony that we have of the Thing from Nature, and the Paffage already alledged out of Mofes, there is

$$
\mathrm{S}_{2} \text { ano- }
$$


another for which we are alfo obliged to the fame Author, that acquaints us there were botb even in Paradife it felf.

* Gen. ii. 'Tis in his fecond Chapter*. The name "13, 12. of the firft River is Pifon: that is it which compafseth the whole Land of Havilah, where there is Gold. And the Gold. of that Land is good: there is Bdellium and the Onyx-fone. He fpeaks here, I grant, only in the Prefent Tenfe, there is Gold : but muft mean not only that there was Gold and Gemms there in his time, but that there was fo likewife from the beginning of the World, of which he is giving an Account in thefe two Chapters, or, with Submiffion, I conceive 'twould not be any thing to his purpofe. He is here fpeaking of Paradife; which he reprefents as a moft charming and delightful Place : befett with every Tree that is VVerf. 9. pleafant to the fight, and good for food $\|$ : watered with refrefhing Streams and excellent Rivers: and abounding with Things not only ufeful and convenient, but even the moft rare and valuable, the moft coftly and defirable: particularly Gold, Precious Stones, and Perfumes; which were all much efteemed and admired by the Jews, to whom 
he wrote this. Nor is it any Paradox, notwithftanding that Diffolution of the Earth which happened at the Deluge*, " Part 2. to fuppofe there was this or that Metall or Mineral in the fame Part of the Globe afterwards where it was before that happened. The Water of the Abyls indeed changed its Place, during the time: So did the Sea, and bore the Bodies it contained, many of them, out along with it. But for the Terreftrial Parts of the Globe, Metalls, Minerals, Marble, Stone, and the reft, they, though diffolved, and affumed up into the Water, did not flitt or move far, but, at the general Subfidence, fettled down again in or near the fame Place from which they were before taken up. For the Water was all out upon the Face of the Earth before ever the fe ftirr'd, or were fetch'd up out of their native Beds: and they were all funk down into the fame Beds again, before the Water began to Rhift away back to its old Quarters; fo that it could not contribute any thing to the Removal of them. Even the very Vegetables, and their Seeds, which were many of them naturally lighter than the Water, aflifted by the 
262 The Natural Hiffory Part VI. heavier Terreftrial Matter that had in this Jumble and Confufion faften'd and ftuck to them, fell all to the bottom: and the Water was in great meafure clear, and difengaged from the Earthy Mars, before it went off. And 'twas well it was fo; for had the Mineral Maiter of the Globe not been held to its former Station, but hurried about and tranfpoied from place to place, 'tis fcarcely to be conceived how many and great Inconveniences it would have occafioned. The fame likewife for Vegetables. Had the Seeds of the Pepper Plant, the Nutmeg, the Clove, or the Cinnamon Trees, been born from Fava, Banda, the Moluccoes, and Ceylon, to thefe Northern Countries, they mult all have ftarved for want of Sun: or had the Seeds of our colder Plants hifted thither, they wou'd have been burnt up and fpoil'd by it. But Things generally kept to their proper Places: to their old natural Soil and Climate; which had they not done, all would have been confounded and deftroyed. 'Tis true, the Vegetables, being comparatively lighter + Confer. than the ordinary Terreftrial Matter $\underset{P r i 2.2}{+}$ onf of the Globe, fubfided laft + ; and conC. 35 E. 3 .

fequently 
fequently lying many of them upon the Surface of the Earth, thofe which were of confiderable Bulk, as the bigger forts of Trees, which had large and fpreading Heads, would lye with their Branches ftretch'd up to a great height in the Water, (and, when that was withdrawn in the Air $\|_{3}$ ) and fo being very much in the Waters way, Poffure ${ }^{\prime}$ tis when it began to depart and retire probsble back again, would be apt to be remo- ${ }^{\text {the }}$ Tre Olive $_{\text {lay }}$ ved and driven forward along with it, from wbich efpecially thofe which lay in fuch pla- phe Dove ces where the Current happened to run t the Leaf ftrong. Accordingly we now find of that he thefe Trees in Inlands, and the other ${ }^{2}$ ranghto Noah, bleaker and colder Parts of the Earth, Gen, viiiwhere none now do, or perhaps ever did, grow*. And there they are of "conf. mighty ufe to the Inhabitants, afford-pag. 1130 ing them a Supply of Timber which fupra. their own Country doth not yield, and which they employ not only for Fewel, which yet is much needed in thofe cold Countries, but for Building likewife, and many other Purpofes; whereas in the Places whence they were thus driven they would have been ufelefs, yea but an Incumberance, and might be eafily fpared, for as long as the Seeds

$$
\mathrm{S}_{4} \text { remained }
$$


remained behind, lodged in a natural and agreeable Soil, all was fafe enough: they would foon vegetate, and fend forth a new Sett of Trees there, fo that 'twas not much matter what became of the Old ones. But to the Parts whereunto they were thus removed, they are of great advantage. And, which is in truth very remarkable, and an Argument that there was fomething more than meer Chance in this Affair, there are hardly any Countries that are deftitute of Timber of their own growth, which have not a very large Supply of thefe Stray-Trees, if I may fo call them. But to proceed. After that the Terreftrial Matter was once funk down into its feveral Beds, and well fettled there, the Mountains were calt up, and the Springs and Rivers burft forth, in fuch Numbers, and at fuch Diftances from one another, in all Parts of the Globe, as beft anfwered the Neceffities and Expences of each : and therefore undoubtedly in much the fame Places that they were before the Deluge. All Things were fo contrived and ordered in the re-fitting up the Globe at this time, that they might befe execute and perform each their 
Part VI. of the Earth.

feveral Ends and Offices. There were the fame Meafures taken, and the fame Procefs ufed in this Re-formation of it, that were when 'twas firft built: and much fuch an Earth arofe out of the Deluge, as at the Creation, fprung out of Nothing II. But the Reader \| Vid.pag. will more clearly difcover all this, with 97. Supra, the Reafons of it, if he give but him. felf the trouble to compare Part 2. Conf. 2. O feq. Part 3. Sect. 1. pag. 154. ofeq. \&. Sect. 2. Conf 2, 3, \& 7. Part 4 . Conl. 3. \& Part 6. Conn. 9. This premifed, 'twould be, I think, not ftrange fhould we find Paradife at this Day where Adam left it : the fame Rivers: the fame Face of the Ground: the fame Metalls and Minerals, that then there were. And I the rather Note this, becaufe I fee there are fome fo earneft in queft of it. Learned Men have been now a long time a fearching after the happy Country from which our firft Parents were exiled. If they can find it, with all my heart: and there have been fome that have fought it with that Induftry that I think they deferve it for their pains whenever they make the Difcovery. 
To deal freely, I am of opinion there's no part of the prefent Earth that does come up fully to the Mofaick Defcription of Paradife. The Country about Babylon, or Bagdet, bids faireft for it : and I am perfuaded that it was thereabouts. But if fo, whoever thall compare this Country, as now it ftands, with that Defcription, will find that it fuftained fome Alterations from the Deluge, perhaps more than any Part of the Earth befides. And there's an obvious Reafon why it fhould. There was a Paradife before, but was to be none after the Deluge. The Cafe was. altered, and the Reafon of the thing ceafed. So that all that denominated it Paradife, and that diftinguifh'd it frow the reft of the Globe, was lop'd off by the Deluge, and that only left which it enjoyed in common with its neighbour Countries. Upon the whole, 'tis, I think, apparent that what I offer in this Difcourle is fo far from doing any Diskindnefs to the Caufe thefe Gentlemen, are, and have been 1o long, engaged in, that it does them a real Service, and helps them out with the main thing whereat they ftuck: 
Part VI. of the Earth.

Atuck : fairly folving all Difficulties in the Mofaick Relation of Paradife. Wherefore now to proceed to the laft Head to be difcufs'd, the Viciffitude of Seafons, Summer and Winter, Hot and Cold, in the Antediluvian World.

And that there really was fuch a Vicifitude we need not go any further for proof than to the aforefaid Animal and Vegetable Bodies ftill preferved; the general Tenour of them fpeaking it out fo plainly as to leave no room for doubt. There are, we know, fome forts of Vegetables which confift of Particles very fine, light, and active: and which therefore require only a fmaller degree of Heat to raife them * "Vid. Pary from out the Earth up into the Seeds, 3. S\&z. I. Roots, or Bodies of thofe Vegetables, Conf. 8 . for their growth and nourifhment. So that for the raifing of thefe, the Suns Power, when only lefier, is fufficient. And therefore they begin to appear in the earlyer Months, in $\mathrm{Fe}_{e-}$ bruary and March; when they firft peep forth of the Ground: after a while they difplay themfelves, thewing their whole Tire of Leaves : then their Flowers: next their Seeds : and 
laftly when, in the following Months, April and May, the Sun is further advanc'd, and (to fpeak in the Phrafe of the Vulgar, which I choofe all along for the fake of plainnefs) hath gained a greater ftrength, the Heat becomes too powerful and boifterous for them; it now mounting up the Terreftrial Matter with fuch force and rapidity, that the Plants cannot affume that part of it which is proper for their Nourifhment, as it paffeth through them, nor incorporate it with them, as before they were wont when it pafs'd more gently and leifurely. Nay the Heat at length grows fo great, that it again diffipates and bears off thofe very Corpufcles which before it brought; the Parts of thefe Plants being very tender, as confifting of Corpufcles which are extremely fmall and light, and therefore the more eafily dififipable. So that then thefe Plants dye away, fhrink down again into the Earth, and all, fave only their Roots and Seeds, vanifh and difappear. But when the Sun's Heat is thus far advanc'd, 'tis but juft come up to the pitch of another Sett of Vegetables: 


\section{Part VI. of the Earth.}

and but great enough to excite and bear up the Terreftrial Particles, which are more crafs and ponderous. And therefore thofe Plants which confift of fuch, begin then to fhoot forth, and difplay themfelves. So that the Months of April and May prefent us with another Crop and Order of Plants. For the fame reafon alfo, Fuse, Fuly, and Auguft go farther, and exhibit a ftill different Shew of Vegetables, and Face of Things. But when, in the Months of September and October, the Sun's Power is again diminifh'd, and its Heat but about equivalent to that of March and April, it again fuits the Plants which were then in feafon, fo that they many of them fpring up afreth in the /e Months, and flourifh over a-new, in like manner as before they did in thofe; till being check'd by the Cold of the fucceeding Winter, the Sun being gone off, and having now no longer Power great enough to bring up and fupply them with frefh Matter, they prefently begin to decline for want thereof, and at length quite dwindle away and difappear, untill the Arrival of the Spring. Seafon, when they take 
their Turns over again as formerly. Yea the more tender and frigitive Parts, the Leaves, and the like, of many of the more fturdy and vigorous Vegetables, Shrubs, and Trees, fuffer the fame Fate, and fall off for want of the Supply from beneath; thofe only which are more tenacious, confiftent, and hardy, enduring the Brunt, and making a fhift to fubfint for the time without fuch Recruit and Reparation. 'Tis therefore, we fee, moft apparent that this Succeffion of Thirgs upon the Face of the Earth, is purely the Refult and Effect of the Viciffitude of Seafons : and is as conftant and certain as is the Caufe of that Viciffitude, the Sun's Declination : fo certain, that were a Man kept for fome time blindfold, in fuch manner that he could have no Notice how the Year pafs'd on, and were at length turn'd forth into the next Field or Garden, he would not need any other Almanack to inform him what Seafon of the Year it then was.

But if inftead of this Variation of Heat, we fuppofe that there was an Equality or conftant Temperature of 
it ibefore the Deluge, which is what the Theorift contends for, the Cafe would be very much altered, and that altogether for the worfe. A Man can hardly at firft imagine what a Train of ill Confequences would follow from fuch a Condition and Pofture of Things; of which 'twould not be the leaft that fuch a Mediocrity of Heat would deprive the World of the mort beautiful and the moft ufeful Parts of all the whole Creation: and would be fo far from exalting the Earth to a more happy and Paradifiacal State, which is what he brought it in for, that 'twould turn it to a general Defolation, and a meer barren Wildernefs, to fay no worfe. Such an Heat would be too little for fome forts of Vegetables, and too great for others. The more fine and tender Plants, thofe which will not bear a degree of Hear beyond that of April, would be all burnt up, and detroyed by it: whilf it could never reach the more lofty and robuft, nor would there be near Heat enough to ripen their Fruits and bring them to Perfection. Nothing would fuit and hit all, 
all, and anfwer every End of Nature, but fuch a gradual Increafe and Decreafe of Heat as now there is. I muft not defcend to the Animal World, where the Inconveniences would be as many and as great as in the Vegetable: and fuch a Situation of the Sun and Earth as that which the Theorift fuppofes, is to far from being preferable to tbis which at prefent obtains, that this hath infinitely the Advantage of it in all refpects.

Be that how it will, for I have no need to infilt upon it, but may take the thing in his way, and fuppofe that fuch a Temperature would have all the happy Effects that he expects from it ; yet there is one very confiderable Fbenomeron of the Vegetable Remains of that Earth, which affords us a fure and plain Indication that there was not then any fuch Temperature. From the $\int e$ it clearly appears that there was the fame Order and Succeffion of Things upon the Face of the Earth that there is at this time. Now this Succeffion being, as we have feen, caufed meerly by the $\mathrm{Va}$ riation of the Sun's Heat, it muft needs follow 


\section{Part VI. of the Earth.}

follow, that there was then the fame Variations of it, and confequently the fame Alternations of Seafons, that now there is. Had there been an Equality of Heat, if we grant that it could have produced all the Plants in Nature, which 'tis impoffible it ever fhould, it muft have done it indifferently and uncertainly. There could be no reafon why they fhould flourifh at any one fet time rather than another; that's peculiarly the Effect of the Sun's Variation. So that they muft needs have been all in Confulion, and this Succeffion of Things would have been quite overturned. The Plants which now appear in the moft different and diftant Seafons, would have been all in Prime, and flourifhing together at the fame time: fo that they would have had February and May, Foly and Septensber, all in one Scene. Nay, the feveral Individuals of the fame kind muft have been as greatly at odds : one arrived to Seed, and that fully ripe, and ready to thed, whillt another was not fo much as come to Flower, but in as differing a State and Hue as can be. In brief, there $\mathrm{T}$ 
274 The Natural Hiftory Part VI. would have been all the Diverfity, Uncertainty, and Diforder, in the Vegetable Kingdom that can well be conceived. Which indeed is no more than what he freely owns: telling us that then Every Seafon was a Seed-time to Nature, and every Seafon an Harveft. This is what he does, and muft grant: and this is as mnch as is needful for the overturning his Hypothefis. For the Vegetable Remains of that Earth fay no fuch thing: they give not any the leaft Countenance to thefe ConjeCtures, but the quite contrary : and the fe, being many of them enclofed in very fine and clofe Stone, are preferved to this day very curioufly and entire to Admiration. By them we may eafily judge how Things then ftood. And there is fo great an Uniformity, and general Confent amongft them, that from it I was enabled to difcover

+ Gsn. vii. rr. In the fecond Month, the feventeenth day of the Month, .. were all the Fountains of the great Deep broken $u p$, and the windows of Heaven were opened. Mofes rriting to the Jews bis Country-mers, makes ufe of the Form of the rear then recived amongst them, wobich what time of the year it was that the Deluge began +; the whole Tenour of thefe Bodies thus preferved clearly pointing forth the Month 


\section{Part VI. of the Earth.}

of $M_{a y} \|$; nor have I which was indectd the fritt and ever met with fo much as one fingle Plant, or other Body, amongft all thofe vaft multitudes which I have carefully view. ed, that is peculiar to any other Seafon of the Year: or any thing that happens earlier or later: any of them fhort, or any further advanc'd in Growth, Seed, or the like, than they now ufually are in that Month; which furely I muft needs have moft ancient, but had been difufid during the time of their sbode in Egypt, and but newly reeftablifh'd when this was wrote [Exod. xii. 2.] In this, Nifan, or, as 'twos alfo call'd, Adib was the first Month: and liar the Je cond, upon the 17th day whereof the waters of the Deluge cane forth, according to this Relas tion. Aidd truly the time (wbich is not a little remarkable) falis within the Compals here chalk'd out by Nature fo very punctually. that one can fcarcely forbear cancluding that the fe Strokes and Lines of Nature, and those of that Relation, came both from the Same Hond; but this only by the by. The Particulars of the Computation I bere ase thall be given at full ellewhive, they being too bulky for this place. \|Corf. Part 3. Seat. 2. Cons. 5.

done, had there really been fuch an equality of Seafons, and conftant temperature of Heat as is imagined by the Theorilt. There are fome Phenomena of the Animal Remains of that Earth which afford us more Arguments to the fame purpore, and thofe not lefs concluding than the others; but thefe I thall wholly wave for the prefent, there being indeed no occafion to make ufe of them here.

$$
T_{2} \text { I hall }
$$


I thall now only look a little into the Mofaick Archives, to obferve what they furnifh us with upon this Subject, and I have done; for I perceive I have, before I am aware, much exceeded the Meafures I defign'd, which on fo copious a Subject 'rwas hard not to do. Gen. 1. 14. And God Jaid, let there be LiGHTS in the Firmament of the Heaven, to divide the Day from the Night: and let them be for Signs, and for SEASONS, and for Days and $\Upsilon_{\text {ears. }}$. This Paffage, we fee, does not at all favour the Opinion that there was no Variation of Seafons before the Deluge: fo far from it, that thould a Man go about with never fo fet Study and Defign to defcribe fuch a Natural Form of the Year as is that which is at prefent eftablifh'd, he could fcarcely ever do it in fo few Words again that were fo fit and proper, fo full and exprefs ; efpecially if, by Signs, in this place, Months are intended, for then we have here firlt the $\Upsilon_{e a r}$ : and that fubdivided into its ufual Parts, the four Quarters or Seafons, the twelve Signs or Months, and Days; nay at the fame time, from the 19 th Verfe, we learn that this Eftablifhment is, within four days, 


\section{Part VI. of the Earth.}

days, as old as the World. But further, Gen. viii. 21, 22. And the Lord Jaid in bis beart, I will not again curfe the ground, ... neitber will I again Jmite any more every thing living as I bave done. While the Earth remaineth, Seed-time and Harvest, and Cold and Heat, and Summer and Winser, and Day and Night, Sall not ceafe. This was pronounc'd upon Noab's Sacrificing, at his coming forth of the Ark, after the Deluge was over: and implies, that there had indeed then lately been a mighty Confulion of Things, for the time : an Interruption and Perturbation of the ordinary Courfe of them : and a Ceffation and Sufpenfion of the Laws of Nature: but withall gives Security and Affurance that there fhould never be the like any more to the End of the World: that for the future they fhould all run again in their old Chanel : and that particularly there fhould be the fame Viciffitudes of Seafons, and Alternations of Heat and Cold that were before the Delinge.

$$
\text { FINIS. }
$$


Books Printed for Richard Wilkin at the King's-Head in S. Paul's C Church. rard.

Trters concerning the Love of God, 1 between the Author of the Propofal to the Ladies, and $\mathrm{Mr}$. Fohn Norris; wherein his late Difcourfe, fhewing that it ought to be entire and exclufive of all other Loves, is farther clear'd and juftified, Oizavo.

A Propofal to the Ladies for the Advancement of their true and greateft Intereft. By a Lover of her Sex. Twelves. The Second Edition.

A Vindication of the Truth of Chriftian Religion againft the Objections of all Modern Oppofers. By Fames $A b$ badie, D. D. Octaru.

A fecond Part of the Enquiry into feveral remarkable Texts of the Old and New Teltament, which contain fome Difficulty in them: with a probable Refolution of them. The fecond Edition. O¿zavo.

A Difcourfe concerning the Authority, Style, and Perfection of the Books 
of the Old and New Teftament; with a continued Illuftration of feveral diffi. cult Texts of Scripture throughout the whole work. Both by Fobn Edwards, B. D. fometime Fellow of St. Fobr's College in Cambridge. OEFavo.

The Glorious Epiphany, with the Devout Chriftians Love to it. The Second Edition. Octavo.

Search the Scriptures. A Treatife fhewing that all Chriftians ought to read the Holy Books; with Directions to them therein.

A Difcourfe concerning Prayer, efpecially of frequenting the daily Publick Prayers. All three by the Reverend Sim. Patrick, D. D.

The Old Religion demonftrated in the Principles, and defcribed in the Life and Practice thereof. By $\mathcal{F}$. Goodman, D. D. The Second Edition. Twelves. 





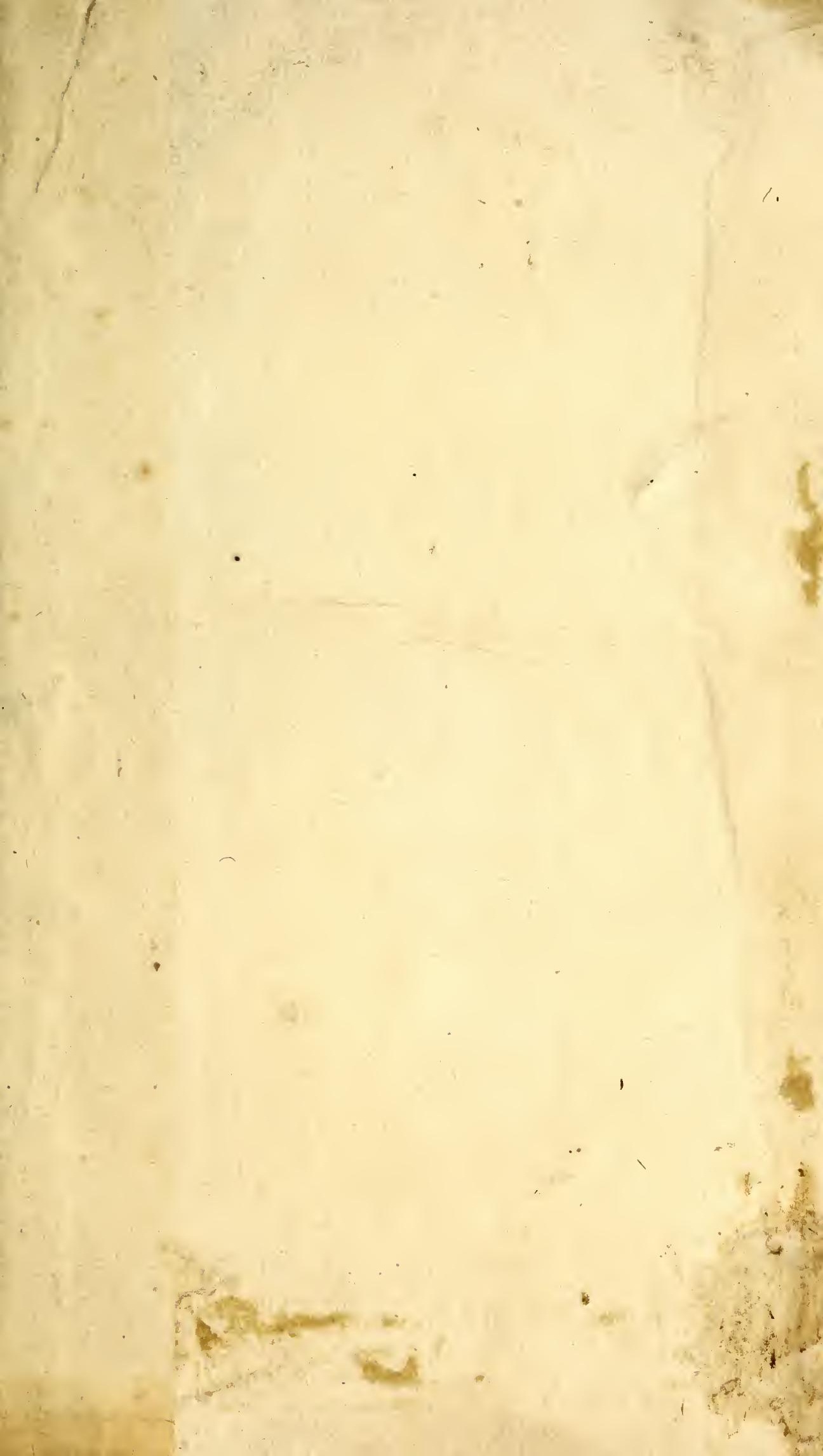


